Prepared in cooperation with the Lake County Forest Preserve District and the Illinois State Geological Survey

\title{
Hydrology, Water Quality, and Causes of Changes in Vegetation in the Vicinity of the Spring Bluff Nature Preserve, Lake County, Illinois, May 2007-August 2008
}
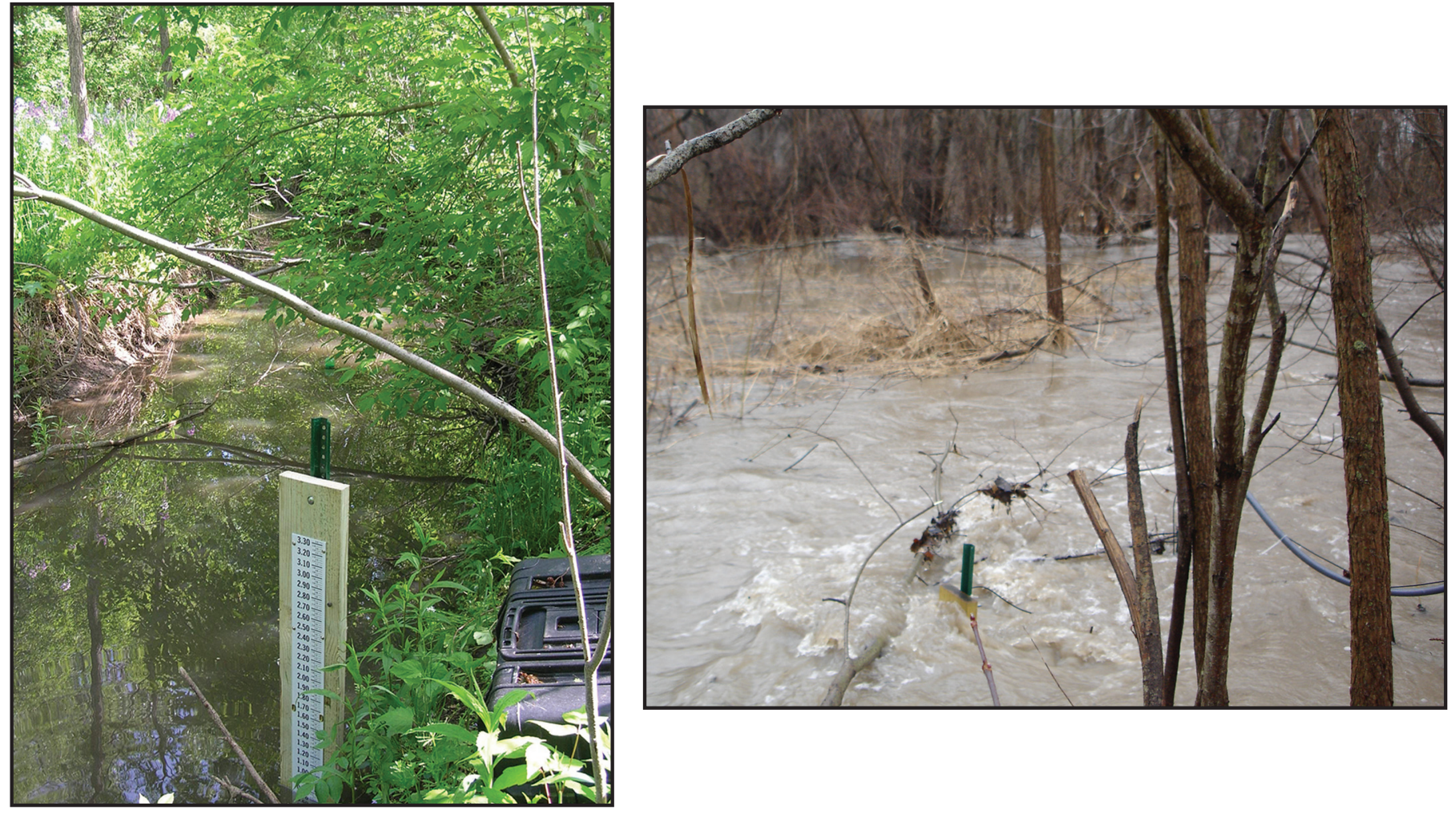

Scientific Investigations Report 2009-5237 
Cover: Left-Staff gage on Dead Dog Creek at DD1 during normal water levels, May 28, 2007. (Photograph by Debbie Maurer, Lake County Forest Preserve District, Grayslake, Illinois.)

Right-Staff gage at Dead Dog Creek at DD1 during high water levels immediately after a spring precipitation event, May 31, 2008. (Photograph by Debbie Maurer, Lake County Forest Preserve District, Grayslake, Illinois.) 


\section{Hydrology, Water Quality, and Causes of Changes in Vegetation in the Vicinity of the Spring Bluff Nature Preserve, Lake County, Illinois, May 2007-August 2008}

By Robert T. Kay, James J. Miner, Debbie A. Maurer, and Charles W. Knight

Prepared in cooperation with the Lake County Forest Preserve District and the Illinois State Geological Survey

Scientific Investigations Report 2009-5237

U.S. Department of the Interior

U.S. Geological Survey 


\section{U.S. Department of the Interior \\ KEN SALAZAR, Secretary \\ U.S. Geological Survey \\ Marcia K. McNutt, Director}

U.S. Geological Survey, Reston, Virginia: 2010

For more information on the USGS—-the Federal source for science about the Earth, its natural and living resources,
natural hazards, and the environment, visit http://www.usgs.gov or call 1-888-ASK-USGS
For an overview of USGS information products, including maps, imagery, and publications,
visit http://www.usgs.gov/pubprod
To order this and other USGS information products, visit http://store.usgs.gov

Any use of trade, product, or firm names is for descriptive purposes only and does not imply endorsement by the U.S. Government.

Although this report is in the public domain, permission must be secured from the individual copyright owners to reproduce any copyrighted materials contained within this report.

Suggested citation:

Kay, R.T, Miner J.J., Maurer, D.A., and Knight, C.W., 2010, Hydrology, water quality, and causes of changes in vegetation in the vicinity of the Spring Bluff Nature Preserve, Lake County, Illinois, May 2007-August 2008: U.S. Geological Survey Scientific Investigations Report 2009-5237, 73 p. 


\section{Contents}

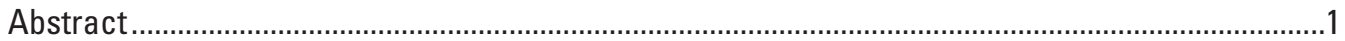

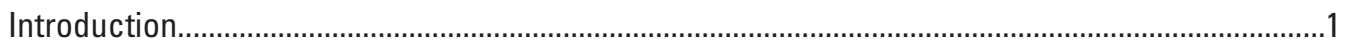

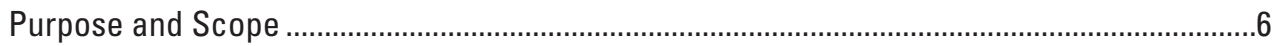

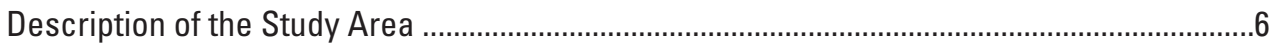

Watersheds and Land Use .......................................................................................

Kellogg Creek and Dead Dog Creek ...................................................................11

Bull Creek and Dead River .....................................................................................11

Meteorological Data ...................................................................................................13

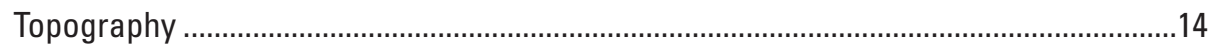

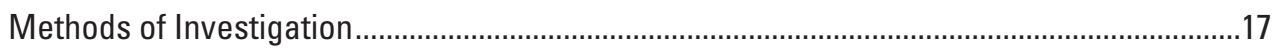

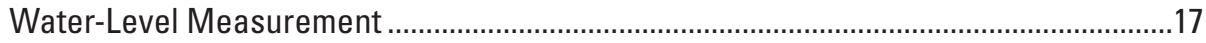

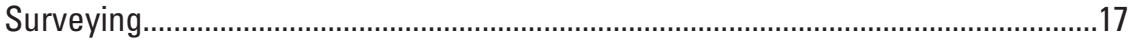

Surface-Water Discharge ………………………….......................................17

Water-Quality Sampling .......................................................................................19

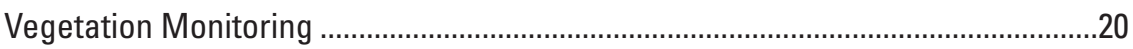

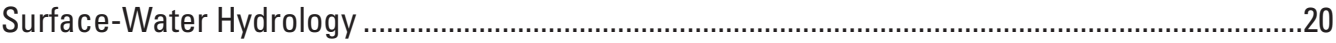

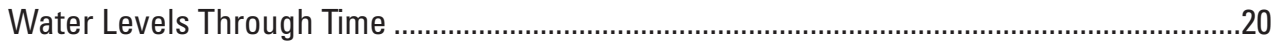

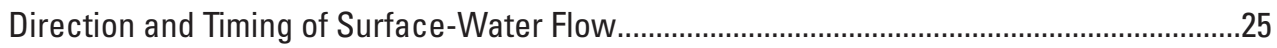

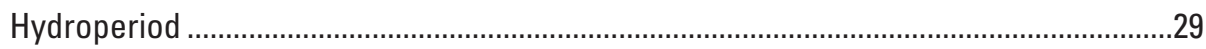

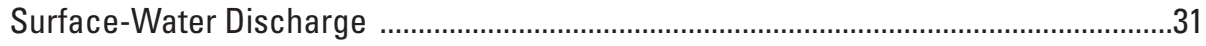

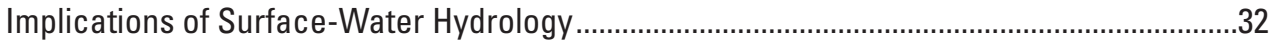

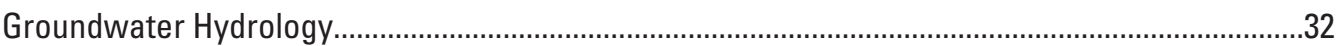

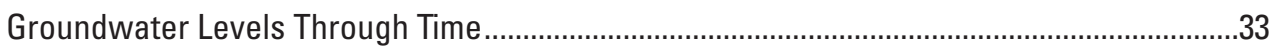

Hydroperiods Associated With Different Plant Communities ................................................34

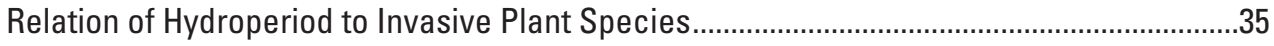

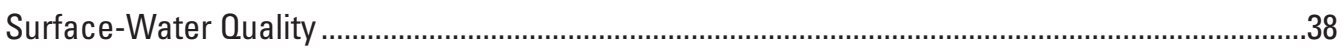

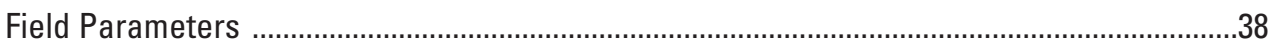

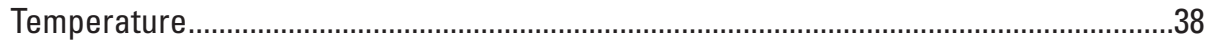

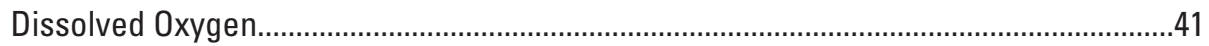

$\mathrm{pH}$

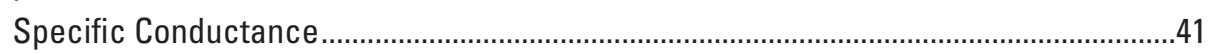

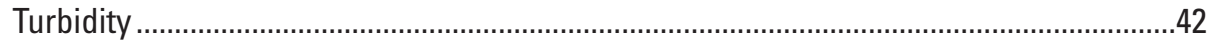

Chloride

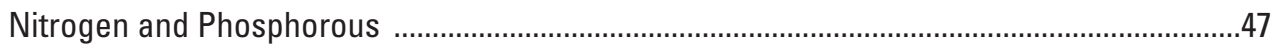

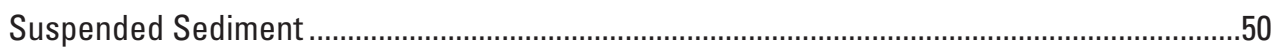

Apparent Attenuation of Suspended Sediment, Chloride, Dissolved Phosphorous, and Nitrate Within the Wetland Complex ............................................................................53

Relation of Hydrology and Water Quality to Invasive Species......................................................54

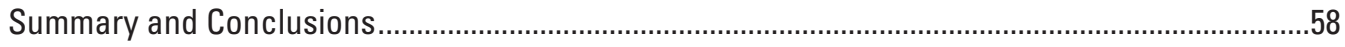

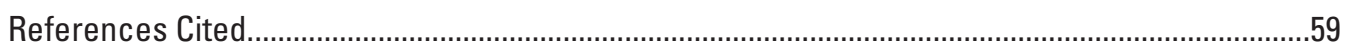

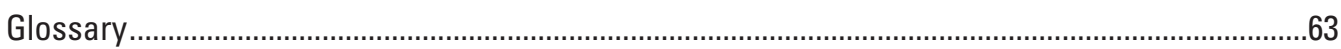

Appendix 1. Water-level measurements in the vicinity of Spring Bluff Nature Preserve,

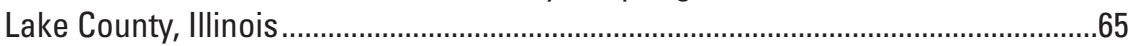




\section{Figures}

1-7. Maps showing:

1. Location of Spring Bluff Nature Preserve, Chiwaukee Prairie State Natural Area, Illinois Beach State Park, and selected site features, near Winthrop Harbor and Waukegan, III.

2. Location of selected surface-water bodies and monitoring points in the vicinity of the Spring Bluff Nature Preserve, Chiwaukee Prairie State Natural Area, and Illinois Beach State Park, near Winthrop Harbor and Waukegan, III.

3. Location of selected features in the vicinity of the Spring Bluff Nature Preserve, Winthrop Harbor, III.

4. Location of selected features in the vicinity of the Southern Unit of the Illinois Beach State Park near Waukegan, III.

5. Land cover in the watersheds for Kellogg Creek, Dead Dog Creek, Bull Creek, and the Dead River, northeastern Lake County, III.

6. Topography in the vicinity of the Spring Bluff Nature Preserve, Winthrop Harbor, III

7. Topography in the vicinity of the Southern Unit of the Illinois Beach State Park near Waukegan, III.

8-12. Graphs showing:

8. Water levels in Dead Dog Creek at gage DD1, May 25, 2007-June 11, 2008, in the vicinity of the Spring Bluff Nature Preserve, Winthrop Harbor, III.

9. Water levels at gage W1, May 24, 2007-June 11, 2008, in the vicinity of the Spring Bluff Nature Preserve, Winthrop Harbor, III.

10. Precipitation measured at the National Oceanic and Atmospheric Administration Station, Kenosha, Wis., May 1, 2007-June 30, 2008

11. Water levels at gage DD1 in the vicinity of the Spring Bluff Nature Preserve, Winthrop Harbor, III., June 24 and 25, 2007

12. Water levels in the Dead River at gage DR3 in the Southern Unit of the Illinois Beach State Park, near Waukegan, III., May 24, 2007-June 11, 2008

13-14. Maps showing:

13. Surface-water levels and flow directions in the vicinity of the Southern Unit of the Illinois Beach State Park, near Waukegan, III., April 29, 2008

14. Surface-water levels, specific conductance, and flow directions in the vicinity of the Spring Bluff Nature Preserve, Chiwaukee Prairie State Natural Area, and Northern Unit of the Illinois Beach State Park, near Winthrop Harbor, III., April 29, 2008.

15-20. Graphs showing:

15. Hydrograph showing water-level responses to June 8, 2008, rainfall, Spring Bluff Nature Preserve, Winthrop Harbor, III.

16. Depth to groundwater in monitoring wells, Spring Bluff Nature Preserve, Chiwaukee Prairie State Natural Area, and Illinois Beach State Park, near Winthrop Harbor and Waukegan, III., July 2007-August 2008

17. Average depth to groundwater in each type of wetland community, Spring Bluff Nature Preserve, Chiwaukee Prairie State Natural Area, and Illinois Beach State Park, near Winthrop Harbor and Waukegan, IIl., July 2007-August 2008 
18. Surface-water temperatures recorded at well locations in the vicinity of the Spring Bluff Nature Preserve, Winthrop Harbor, III., September 2007-June 2008

19. Specific conductance of surface water and amount of precipitation at selected gages and well locations in the vicinity of the Spring Bluff Nature Preserve, Winthrop Harbor, III., July 2007-July 2008..

20. Turbidity and precipitation in Dead Dog Creek and wetlands in the vicinity of the Spring Bluff Nature Preserve, Winthrop Harbor, III., October 2007-July 2008

21-22. Maps showing:

21. Concentrations of chloride and dissolved nitrate plus nitrite as nitrogen in surface water in the vicinity of the Spring Bluff Nature Preserve, Chiwaukee Prairie State Natural Area, and Northern and Southern Units of the Illinois Beach State Park near Winthrop Harbor and Waukegan, III., May 13, 2008

22. Concentrations of dissolved phosphorous in surface water in the vicinity of the Spring Bluff Nature Preserve, Chiwaukee Prairie State Natural Area, and Northern and Southern Units of the Illinois Beach State Park near Winthrop Harbor and Waukegan, III., April 2, 2008

23-29. Graphs showing:

23. Water-level elevation and concentration of suspended sediment in Dead Dog Creek at gage DD1, Spring Bluff Nature Preserve, Winthrop Harbor, III., March 26-April 2, 2008.

24. Concentration of suspended sediment in the Spring Bluff Nature Preserve, Northern Unit Illinois Beach State Park, and Chiwaukee Prairie State Natural Area, near Winthrop Harbor and Waukegan, III., March 26April 2, 2008.

25. Concentration of suspended sediment in Bull Creek at gage DR1 and water level of Dead Dog Creek at gage DD1, near Winthrop Harbor and Waukegan, III., April 10-13, 2008.

26. Relation of Typha spp. importance value to days of inundation at vegetationmonitoring points in the Spring Bluff Nature Preserve, Northern Unit Illinois Beach State Park, and Chiwaukee Prairie State Natural Area, near Winthrop Harbor and Waukegan, III., July 24, 2007-August 27, 2008

27. Relation of Typha spp. importance values to average depth to groundwater at vegetation-monitoring points in the vicinity of the Spring Bluff Nature Preserve, Northern Unit Illinois Beach State Park, and Chiwaukee Prairie State Natural Area, near Winthrop Harbor and Waukegan, III., July 24August 27, 2008.

28. Relation of species richness index (SRI) values to average depth to groundwater at monitoring-well locations in the Spring Bluff Nature Preserve, Northern Unit Illinois Beach State Park, and Chiwaukee Prairie State Natural Area, near Winthrop Harbor and Waukegan, III.

29. Relation of Typha spp. importance values to specific conductance of surface water in the Spring Bluff Nature Preserve, Northern Unit Illinois Beach State Park, and Chiwaukee Prairie State Natural Area, near Winthrop Harbor and Waukegan, III. 


\section{Tables}

1a. Federal and State listed animal species identified within the Spring Bluff Nature Preserve, Chiwaukee Prairie State Natural Area, and Illinois Beach State Park, near Winthrop Harbor and Waukegan, III.

1b. Federal and State listed plant species identified within the Spring Bluff Nature Preserve, Chiwaukee Prairie State Natural Area, and Illinois Beach State Park, near Winthrop Harbor and Waukegan, III.

2. Change in vegetation sampled from 1997 to 2005-06 along permanent transects in Spring Bluff Nature Preserve, Winthrop Harbor, III.

3. Gage locations and well locations with associated plant community information in the vicinity of the Spring Bluff Nature Preserve, Chiwaukee Prairie State Natural Area, and Illinois Beach State Park, near Winthrop Harbor and Waukegan, III.

4. Climate data, May 2007-August 2008, Kenosha, Wis. 14

5. Information on gages and wells in the vicinity of the Spring Bluff Nature Preserve, Chiwaukee Prairie State Natural Area, and Illinois Beach State Park, near Winthrop Harbor and Waukegan, III.

6. Estimated evapotranspiration rates at selected gages in the vicinity of the Spring Bluff Nature Preserve, Chiwaukee Prairie State Natural Area, and Illinois Beach State Park, near Winthrop Harbor and Waukegan, III.

7. Summary of water levels at gages in the vicinity of the Spring Bluff Nature Preserve, Chiwaukee Prairie State Natural Area, and Illinois Beach State Park, near Winthrop Harbor and Waukegan, III., May 24, 2007-June 11, 2008

8. Hydroperiod, in days, at selected gages in the wetlands in the vicinity of the Spring Bluff Nature Preserve, Chiwaukee Prairie State Natural Area, and Illinois Beach State Park, near Winthrop Harbor and Waukegan, III., May 24, 2007May 24, 2008

9. Streamflow measurements at selected gages in the vicinity of the Spring Bluff Nature Preserve, Chiwaukee Prairie State Natural Area, and Illinois Beach State Park, near Winthrop Harbor and Waukegan, III., May 24, 2007-May 13, 2008 ......31

10. Characteristics of vegetation, hydrology, and specific conductance sampled, including summaries by plant community, adjacent to wells 1-22 at the Spring Bluff Nature Preserve, Chiwaukee Prairie State Natural Area, and Illinois Beach State Park, near Winthrop Harbor and Waukegan, III.

11. Field-parameter measurements in surface water at gages in the vicinity of the Spring Bluff Nature Preserve, Chiwaukee Prairie State Natural Area, and Illinois Beach State Park, near Winthrop Harbor and Waukegan, III., May 31, 2007-May 13, 2008

12. Concentrations of laboratory-determined constituents in surface water at gages in the vicinity of the Spring Bluff Nature Preserve, Chiwaukee Prairie State Natural Area, and Illinois Beach State Park, near Winthrop Harbor and Waukegan, III., May 31, 2007-May 13, 2008.

13. Pearson correlations and two-tailed $p$-values for selected parameters in the vicinity of the Spring Bluff Nature Preserve, Winthrop Harbor, III., July 24, 2007 July 7, 2008

1-1. Water-level elevation at gages and in wells in the vicinity of Spring Bluff Nature Preserve, Lake County, III. 
1-2. Depth to water at gages and in wells in the vicinity of Spring Bluff Nature Preserve, Lake County, III.

1-3. Water-level elevation at gages and in wells in the vicinity of Spring Bluff Nature Preserve, Lake County, III.

\section{Conversion Factors, Vertical Datum, Abbreviated Water- Quality Units, and Other Abbreviations}

\begin{tabular}{lll}
\hline \multicolumn{1}{c}{ Multiply } & \multicolumn{1}{c}{ By } & \multicolumn{1}{c}{ To obtain } \\
\hline inch (in.) & Length & \\
foot (ft) & 2.54 & centimeter $(\mathrm{cm})$ \\
mile (mi) & 0.3048 & meter $(\mathrm{m})$ \\
\hline & 1.609 & kilometer $(\mathrm{km})$ \\
\hline acre & Area & \\
square foot $\left(\mathrm{ft}^{2}\right)$ & 0.4047 & hectare $($ ha) \\
square inch $\left(\mathrm{in}^{2}\right)$ & 0.09290 & square meter $\left(\mathrm{m}^{2}\right)$ \\
square mile $\left(\mathrm{mi}^{2}\right)$ & 6.452 & square centimeter $\left(\mathrm{cm}^{2}\right)$ \\
\hline & 2.590 & square kilometer $\left(\mathrm{km}^{2}\right)$ \\
\hline \multirow{2}{*}{ cubic foot per second $\left(\mathrm{ft}^{3} / \mathrm{s}\right)$} & Flow rate & \\
\hline & 28.32 & cubic decimeter per second \\
& Evapotranspiration rate & \\
\hline foot per day $(\mathrm{ft} / \mathrm{d})$ & 0.3048 & meter per day $(\mathrm{m} / \mathrm{d})$ \\
\hline
\end{tabular}

Temperature in degrees Celsius $\left({ }^{\circ} \mathrm{C}\right)$ may be converted to degrees Fahrenheit $\left({ }^{\circ} \mathrm{F}\right)$ as follows: ${ }^{\circ} \mathrm{F}=\left(1.8 x^{\circ} \mathrm{C}\right)+32$

Vertical coordinate information is referenced to the North American Vertical Datum of 1988 (NAVD 88).

Elevation, as used in this report, refers to distance above or below NAVD 88.

Horizontal coordinate information used in this report is the North American Datum of 1983 (NAD 83).

Abbreviated water-quality units used in this report: Constituent concentrations are given in milligrams per liter (mg/L). Milligrams per liter are considered equivalent to parts per million at the reported concentrations.

Turbidity measured according to U.S. Environmental Protection Agency approved GLI method 2 is given in Formazin nephelometric units (FNU) and are equivalent to nephelometric turbidity units.

Specific conductance is given in microsiemens per centimeter $(\mu \mathrm{S} / \mathrm{cm})$. 


\section{Other abbreviations used in this report}

CDT

CPSNA

GIS

IBSP

IPCB

ISGS

LCFPD

LCSMC

NLCD

NUIBSP

SBNP

SRI

SUIBSP

USGS
Central Daylight Time

Chiwaukee Prairie State Natural Area

Geographic Information System

Illinois Beach State Park and Nature Preserve

Illinois Pollution Control Board

Illinois State Geological Survey

Lake County Forest Preserve District

Lake County Stormwater Management Commission

National Land Cover Database

Northern Unit Illinois Beach State Park

Spring Bluff Nature Preserve

Species Richness Index

Southern Unit Illinois Beach State Park

U.S. Geological Survey 


\title{
Hydrology, Water Quality, and Causes of Changes in Vegetation in the Vicinity of the Spring Bluff Forest Preserve, Lake County, Illinois, May 2007-August 2008
}

\author{
By Robert T. Kay, James J. Miner, Debbie A. Maurer, and Charles W. Knight
}

\section{Abstract}

Agriculture and urbanization have altered the hydrology and water quality of the coastal wetland complex along the shore of Lake Michigan at the Spring Bluff Nature Preserve and Illinois Beach State Park in northeastern Lake County, Ill., and the adjacent Chiwaukee Prairie State Natural Area in southeastern Wisconsin. Culverts, roads, ditches, and berms installed within the wetland complex have altered the natural directions of surface-water flow and likely have increased the natural hydroperiod in the Spring Bluff Nature Preserve and decreased it in the northern part of the Illinois Beach State Park. Relative to presettlement conditions, surfacewater runoff into the wetlands likely is greater in quantity and higher in concentrations of several constituents, including chloride, nitrate, phosphorous, and suspended sediment. These constituent concentrations are affected by a variety of factors, including the amount of agricultural and urban land use in the watersheds. Hydrologic, chemical, and biologic processes within the wetland communities reduce the concentrations of these constituents in surface water before the water discharges to Lake Michigan by as much as 75 percent for chloride, 85 percent for nitrate, 66 percent for phosphorous, and more than an order of magnitude for suspended sediment. However, concentrations of phosphorous and suspended sediment in surface water increased within parts of the wetland complex. Given these changes, the floristic quality of these wetlands has been altered from the historic condition. Specifically, Typha spp. and Phragmites australis occur in greater numbers and over a larger area than in the past. The spread of Typha spp. and Phragmites australis appears to be enhanced by anthropogenic alterations within the wetland complex, such as increased water levels and duration of inundation and, possibly, increases in the total concentration of dissolved constituents in water.

\section{Introduction}

Wetlands perform many functions, including improvement of water quality and providing habitat for plant and animal species (Mitsch and Gosselink, 2007). However, the hydrology, water quality, and biological communities in many wetlands, including coastal wetlands bordering large areas of the Great Lakes, have been affected by agriculture and urban land-use practices in the wetlands and their watersheds (Geis, 1985; McCullough, 1985; Maynard and Wilcox, 1997; Werner, 2001; Werner and Zedler, 2002; Thrush and others, 2004). Degradation of habitat and reduction in biodiversity within coastal wetlands associated with changes in hydrology, in addition to chemical and sediment loading associated with agricultural and urban land uses, are of concern to land managers throughout the Great Lakes region. The ability of coastal wetlands to reduce sediment and chemical fluxes via surface water into the lakes also is of interest to those trying to protect the lakes.

The Zion Beach-Ridge Plain, located adjacent to Lake Michigan in southeast Wisconsin and northeast Illinois, supports extensive coastal wetland communities and upland habitat. The plain, formed by the deposition and migration of a succession of nearly parallel beach ridges, extends approximately 18 mi north to south from Kenosha Dunes in Wisconsin to Waukegan Harbor in Illinois and has a maximum width of about $1 \mathrm{mi}$ (Chrzastowski, 2001). The part of the beachridge plain within the scope of this study, referred to as the coastal complex, includes the southern part of the Chiwaukee Prairie State Natural Area (CPSNA), the Spring Bluff Nature Preserve (SBNP), and the Illinois Beach State Park and Nature Preserve (IBSP), which are owned and actively managed by public and not-for-profit agencies (fig. 1). 


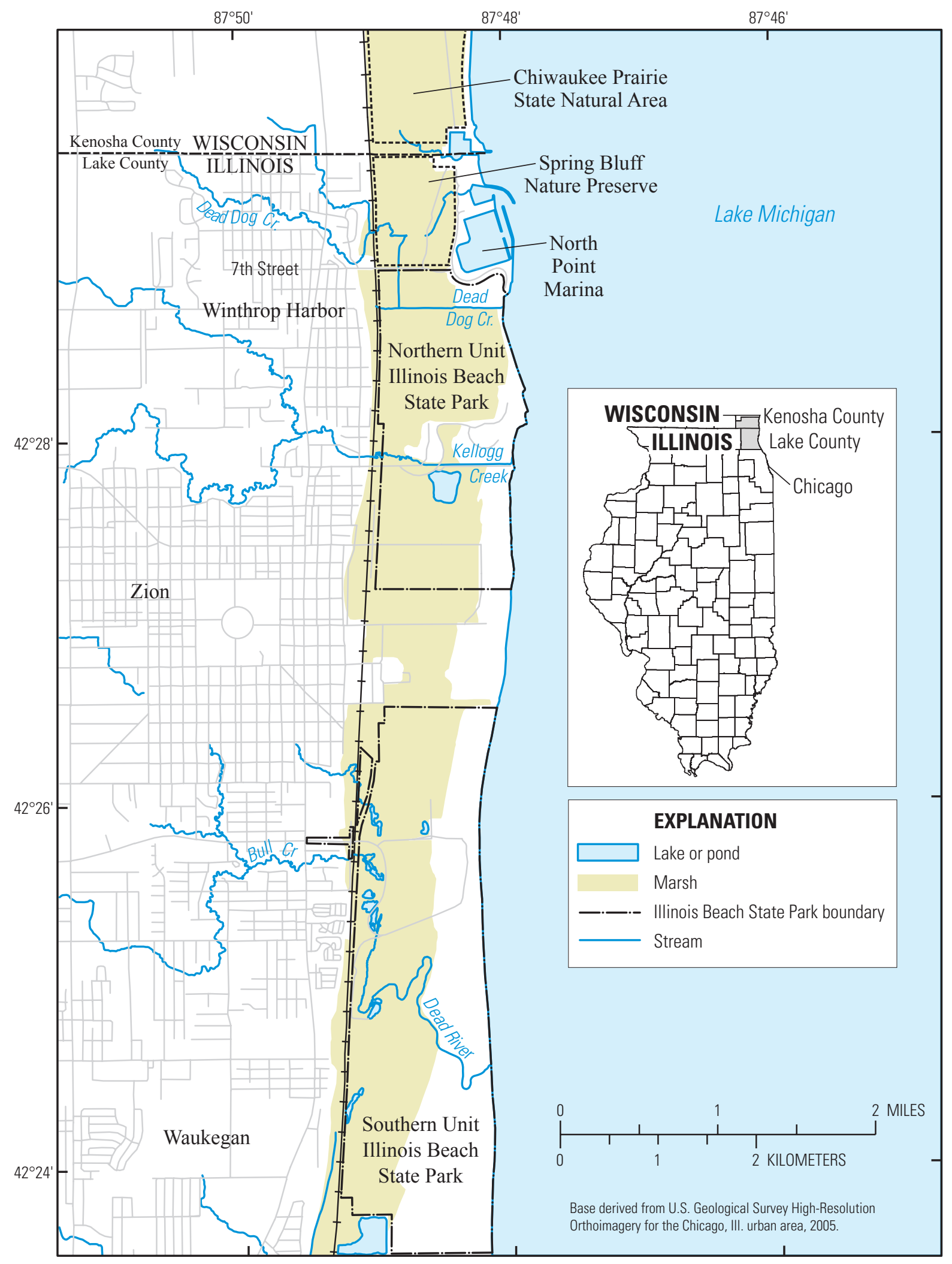

Figure 1. Location of Spring Bluff Nature Preserve, Chiwaukee Prairie State Natural Area, Illinois Beach State Park, and selected site features, near Winthrop Harbor and Waukegan, Illinois. 
The wetlands within this area represent the vast majority of comparatively undisturbed wetlands remaining along Lake Michigan in Illinois and southeast Wisconsin (Chrzastowksi, 2007). Combined, the coastal complex comprises over 4,000 acres of hydrologically linked wetland communities, including high-quality sedge meadows ${ }^{1}$, panne, fens, wet prairies, and emergent marsh habitat, as well as a mosaic of upland communities, including sand savanna, dry, mesic, and wet-mesic sand prairie. IBSP also preserves $6.5 \mathrm{mi}$ of Lake Michigan coastline, including beach and foredune communities. Industry and the construction of residences, roadways, drainage ditches, and recreational areas in and near parts of the wetland complex have altered the natural landscape and appear to have resulted in the degradation of some vegetation communities. However, the coastal complex continues to support numerous state and federally listed species (table 1), as well as remnant high-quality plant communities. In addition, the coastal complex is an important buffer between Lake Michigan and the largely agricultural and urban landscape to the west.
Typha angustifolia and T. latifolia were described as present, and in some locations dominant, in the coastal complex as early as 1912 (Gates, 1912). During the last several decades, land managers at SBNP have documented an increase in abundance and area of Typha spp. (term describing the cattail genus, which in this area consist of the species Typha angustifolia or narrow leaf cattail, T. latifolia or broad leaf cattail, and $T$. $\times$ glauca or cattail hybrids) and Phragmites australis (common reed) within the preserve. This increase has reduced the floristic quality of the wetlands and altered wildlife habitat structure and forage. For example, in a span of less than 10 years, permanent vegetation transects sampled at SBNP showed an increase in importance value of Typha spp. across all transects; in the most extreme case, native species floristic quality decreased from 73.98 to 14.15 (Lake County Forest Preserve District, written commun., 2008; table 2).

${ }^{1}$ Terms included in the glossary are in bold type at their first use in the text.

Table 1a. Federal and State listed animal species identified within the Spring Bluff Nature Preserve, Chiwaukee Prairie State Natural Area, and Illinois Beach State Park, near Winthrop Harbor and Waukegan, Illinois (from surveys by the Lake County Forest Preserve District).

[ST, State threatened; SE, State endangered; FE, Federally endangered]

\begin{tabular}{|c|c|c|c|}
\hline Common name & Scientific name & $\begin{array}{l}\text { Illinois } \\
\text { status }\end{array}$ & $\begin{array}{l}\text { Wisconsin } \\
\text { status }\end{array}$ \\
\hline Redveined leafhopper & Aflexia rubranura & $\mathrm{ST}$ & SE \\
\hline Henslow's sparrow & Ammodramus henslowii & SE & \\
\hline Upland sandpiper & Bartramia longicauda & SE & \\
\hline Veery & Catharus fuscescens & ST & \\
\hline Longnose sucker & Catostomus catostomus & ST & \\
\hline Piping plover & Charadrius melodus & & SE \\
\hline Kirtland's watersnake & Clonophis kirtlandii & SE & \\
\hline Cisco & Coregonus artedii & ST & \\
\hline Lake whitefish & Coregonus clupeaformis & ST & \\
\hline Blanding's turtle & Emydoidea blandingii & ST & \\
\hline Brewer's blackbird & Euphagus cyanocephalus & ST & \\
\hline Hoary elfin & Incisalia polios & SE & \\
\hline Least bittern & Ixobrychus exilis & SE & \\
\hline Richardsons rush & Juncus alpinoarticulatus & SE & \\
\hline Karner blue butterfly & Lycaeides melissa samuelis & $\mathrm{SE}, \mathrm{FE}$ & \\
\hline Black-crowned night-heron & Nycticorax nycticorax & $\mathrm{SE}$ & \\
\hline Silphium borer moth & Papaipema silphii & & $\mathrm{SE}$ \\
\hline Leafhopper & Paraphlepsius lupalus & SE & \\
\hline Pied-billed grebe & Podilymbus podiceps & SE & \\
\hline King rail & Rallus elegans & SE & \\
\hline
\end{tabular}


Table 1b. Federal and State listed plant species identified within the Spring Bluff Nature Preserve, Chiwaukee Prairie State Natural Area, and Illinois Beach State Park, near Winthrop Harbor and Waukegan, Illinois (from surveys by the Lake County Forest Preserve District).

[ST, State threatened; SE, State endangered; FT, Federally threatened]

\begin{tabular}{|c|c|c|c|}
\hline Common name & Scientific name & $\begin{array}{l}\text { Illinois } \\
\text { status }\end{array}$ & $\begin{array}{l}\text { Wisconsin } \\
\text { status }\end{array}$ \\
\hline Round stem foxglove & Agalinis gattingeri & & ST \\
\hline Pale false foxglove & Agalinis skinneriana & ST & SE \\
\hline Marram (beach) grass & Ammophila breviligulata & SE & \\
\hline Bearberry & Arctostaphylos uva-ursi & SE & \\
\hline Prairie milkweed & Asclepias sullivantii & & ST \\
\hline Forked aster & Aster furcatus & ST & \\
\hline Prairie indian plantain & Cacalia tuberosa & & ST \\
\hline American sea-rocket & Cakile edentula & ST & \\
\hline Grass-pink orchid & Calopogon tuberosus & SE & \\
\hline Golden sedge & Carex aurea & SE & \\
\hline Elk sedge & Carex garberi & SE & \\
\hline Little green sedge & Carex viridula & ST & \\
\hline Downey yellow-painted cup & Castilleja sessiliflora & SE & \\
\hline Redroot & Ceanothus ovatus & SE & \\
\hline Seaside spurge & Chamaesyce poligonifolia & SE & \\
\hline Pitcher's thistle & Cirsium pitcheri & ST, FT & \\
\hline Small yellow lady's-slipper & Cypripedium parviflorum & & ST \\
\hline Roundleaf sundew & Drosera rotundifolia & $\mathrm{SE}$ & \\
\hline Capitate spikerush & Eleocharis olivacea & SE & \\
\hline Bearded wheat grass & Elymus trachycaulus & SE & \\
\hline Hairy fimbristylis & Fimbristylis puberlua & & SE \\
\hline Yellow gentian & Gentiana alba & & ST \\
\hline Kalm's St. John's wort & Hypericum kalmianum & $\mathrm{SE}$ & \\
\hline Richardsons rush & Juncus alpinoarticulatus & SE & \\
\hline Ground juniper & Juniperus communis & ST & \\
\hline Trailing juniper & Juniperus horizontalis & $\mathrm{SE}$ & \\
\hline Pinweed & Lechea intermedia & ST & \\
\hline Clustered broomrape & Orobanche fasciculata & SE & \\
\hline Smooth phlox & Phlox glaberrima ssp. interior & & $\mathrm{SE}$ \\
\hline Jack pine & Pinus banksiana & SE & \\
\hline Wood orchid & Platanthera clavellata & SE & \\
\hline Tubercled orchid & Platanthera flava var. herbiola & SE & \\
\hline Eastern prairie fringed orchid & Platanthera leucophaea & SE, FT & SE, FT \\
\hline Purple-fringed orchid & Platanthera psycodes & SE & \\
\hline Pink milkwort & Polygala incarnata & & SE \\
\hline Balsam poplar & Populus balsamifera & SE & \\
\hline Beaked rush & Rhynchospora alba & ST & \\
\hline Dune willow & Salix syrticola & SE & \\
\hline Reddish bulrush & Scirpus microcarpus & SE & \\
\hline Sticky false asphodel & Tofieldia glutinosa & ST & ST \\
\hline Seaside arrow-grass & Triglochin maritima & ST & \\
\hline Bog arrow-grass & Triglochin palustre & ST & \\
\hline Horned bladderwort & Utricularia cornuta & $\mathrm{SE}$ & \\
\hline Flat-leaved bladderwort & Utricularia intermedia & SE & \\
\hline Small bladderwort & Utricularia minor & SE & \\
\hline Marsh speedwell & Veronica scutellata & ST & \\
\hline
\end{tabular}


Table 2. Change in vegetation sampled from 1997 to 2005-06 along permanent transects in Spring Bluff Nature Preserve, Winthrop Harbor, Illinois. Locations of transects are shown in figures 2-4.

[Data from Lake County Forest Preserve District, written commun., 2008]

\begin{tabular}{|c|c|c|c|c|c|c|c|c|c|c|}
\hline $\begin{array}{l}\text { Permanent } \\
\text { transect } \\
\text { location }\end{array}$ & \multicolumn{2}{|c|}{$\begin{array}{c}\text { Relative importance } \\
\text { value of } \\
\text { Typha spp. }\end{array}$} & \multicolumn{2}{|c|}{$\begin{array}{c}\text { Relative importance } \\
\text { value of } \\
\text { Phragmites australis }\end{array}$} & \multicolumn{2}{|c|}{$\begin{array}{c}\text { Relative importance } \\
\text { of bare ground/ } \\
\text { open water }\end{array}$} & \multicolumn{2}{|c|}{$\begin{array}{l}\text { Native species } \\
\text { richness index } \\
\text { (square root) }\end{array}$} & \multicolumn{2}{|c|}{$\begin{array}{c}\text { Mean } \\
\text { vegetation } \\
\text { wetness }\end{array}$} \\
\hline $\mathrm{T} 4$ & 5.2 & 15.5 & 1.5 & 1.7 & 20.9 & 10.1 & 51.1 & 46.2 & -3.9 & -3.9 \\
\hline T5 & 26.9 & 17.3 & .0 & 9.3 & 23.1 & 20.4 & 16.1 & 19.6 & -4.4 & -4.3 \\
\hline
\end{tabular}

One vegetation transect in the northeast part of SBNP lost $15 \mathrm{ft}$ of diverse mesic prairie to complete dominance by Typha spp. from 1997 to 2006 . Anecdotal accounts from local residents indicate that, 40 to 50 years ago, areas in the SBNP that are now dominated by Typha spp. and have standing water for much of the year contained non-Typha spp. vegetation that reached only knee height and rarely contained standing water (Robert Martinelli, resident of Winthrop Harbor, oral commun., 2008). Residents also stated that there were only three specific locations where Typha spp. grew 45 year ago. These accounts are corroborated by the authors, who have identified dead sedge tussocks submerged beneath 4 to 6 in. of water or in areas dominated by Typha spp., indicating a shift in plantcommunity type from assemblages adapted to lower water levels to assemblages adapted to higher water levels. Lake County Forest Preserve District (LCFPD) land managers also have noted that water levels in the wetlands at the SBNP have been higher for longer periods of time than would be expected for the plant communities that are in the wetlands during at least the past 10 years, and that these higher water levels seem to have been accompanied by an expansion of Typha spp. into a larger part of the SBNP, with an accompanying decrease in the diversity of the wetland plant communities. An increase in Typha spp. and Phragmites australis also has been observed in recent years along the banks of the Dead River (fig. 1) and adjacent wetland swales in the IBSP (Deborah Nelson, Illinois Department of Natural Resources, oral commun., 2007).

The spread of invasive plant species often is correlated with the alteration of native communities and is the focus of land-management practices such as chemical and biologic control (Randall, 1996). The factors that facilitate the spread of invasive species are less well understood by land managers and often are not addressed or are occurring in geographic areas outside their jurisdiction. Changes in hydroperiod and water quality within wetlands have been linked to an increase in rate of spread and abundance of invasive plant species, such as Typha angustifolia, T. $\times$ glauca, and Phragmites australis (Spuhler, 1994; Panno and others, 1999; Woo and Zedler, 2002). Typha spp. abundances are strongly correlated with higher water levels and total days of inundation (Tarr and Babbitt, 2006). The spread of invasive wetland plants within the SBNP, and thus the reduction of the diversity of the native flora and change in habitat, may be related to changes in the hydrology and water quality. These changes are primarily increased volume and rate of surface-water flow into the wetland complex; hydrologic alterations within the wetlands related to the construction of roads, ditches, and culverts; and increased chloride, nutrient, and sediment inputs from agricultural and urban land in the watersheds (Mueller and Helsel, 1996; Hamilton and others, 2001).

Invasive species may out compete native species across a spectrum of hydrologic regimes (Kercher and Zedler, 2004a), including Ty $h p a$ spp. in increasingly wet environments such as emergent marshes (Tarr and Babbitt, 2006). However, research also has shown at least some Typha spp. to be adversely affected by periodic drought. Li and others (2004) found that periodic drought reduced photosynthesis, stomatal conductance, and leaf chlorophyll content in T. latifolia, as well as contributing to biomass reduction and substantial reductions in root growth compared to shoot growth. If these findings are true for the Typha spp. present in the wetland complex, then decreased wetness could reduce Typha spp. viability. Other research has shown that Typha spp. responds favorably to decreased soil redox values (Kludze and DeLaune, 1996), as well as stability of water levels (Boers and Zedler, 2008), both of which would occur given long-term increases in saturation related to hydrologic alterations in the wetland complex.

In addition to assessing the effects of urban and agricultural land use on the biotic integrity of the coastal wetlands, assessing the effects of coastal wetlands on mitigating the impact of urban and agricultural land-use practices on the eutrophication of the Great Lakes is of concern. The presence of nutrients such as phosphorous and nitrogen in water and sediments entering the Great Lakes has the potential to increase the algal productivity of the lakes, which can lead to decreased concentrations of dissolved oxygen in the lake water and other adverse impacts. Coastal wetlands can remove nutrients and sediments from surface water entering the Great Lakes (Heath, 1992; Coon and others, 2000), so the loss of these wetlands, or degradation of their ability to function, may have adverse consequences to the ecological integrity of the Great Lakes. 
If not understood, the factors that facilitate the establishment and spread of invasive plants may impede attainment of the long-term conservation goals for coastal wetlands. A comparison of the water quality entering the wetland complex and exiting to Lake Michigan can be used to quantify the role of the wetlands on reducing chemical and sediment loads to the lake. This information may be used to support policies that facilitate improvement of biology and water quality of the wetland complex and the Great Lakes.

To support these objectives, this investigation was done by the U.S. Geological Survey (USGS) Illinois Water Science Center, Illinois State Geological Survey (ISGS), and the LCFPD. The investigation was done to document current (May 2007-August 2008) hydrologic, chemical, and biologic conditions; assess spatial patterns in these conditions; and identify causes of changes in conditions to aid resource managers in conservation planning and future restoration work. The investigation assessed the effects of agricultural and urban runoff, as well as physical alterations to the wetland complex, on the hydrology and water quality of the coastal wetland complex; the effect of the coastal wetland complex on improving water quality entering Lake Michigan; and the effect of changes in hydrology and water quality in the wetland complex on selected current plant-community patterns.

\section{Purpose and Scope}

This report summarizes floristic quality, surface-water and groundwater hydrology, and surface-water quality associated with the Kellogg/Dead Dog Creek ${ }^{2}$ and Bull Creek/Dead River Watersheds in the coastal wetland complex adjacent to Lake Michigan in northeastern Lake County, Ill., and southeastern Wisconsin. Data collection focused on the SBNP but also included the southern part of the CPSNA and parts of the IBSP. Data were collected from May 2007-August 2008. The report describes baseline surface-water and groundwater hydrology and water quality and the hydroperiod of the various wetland types. The report also quantifies types of plants within the various plant communities, identifies patterns of floristic quality and invasive plant dominance across a variety of community types, assesses the effects of the wetland complex on mitigating chemical and sediment loads into Lake Michigan, and identifies the possible causes, extent, and effects of altered hydroperiods and surface-water quality on wetland floristic quality.

\section{Description of the Study Area}

The study area is divided into the northern part and the southern part. The northern part of the study area consists of the SBNP, the northern part of the Northern Unit of the IBSP (NUIBSP), and the southern part of the CPSNA (fig. 2). The northern part of the study area is the area within the polygon defined by well 15 to the north, surface-water measuring points (hereafter known as gages) DD3 and DD4 to the south, Lake Michigan to the east, and gage DD1 to the west (fig. 3). The southern part of the study area consists largely of the area surrounding the Dead River and Bull Creek in the vicinity of the Southern Unit of the IBSP (SUIBSP) and is the area within the polygon defined by gage DR1 to the north and west and the outlet of the Dead River to Lake Michigan near gage DR3 to the south and east (figs. 2 and 4).

\section{Watersheds and Land Use}

The Lake County Stormwater Management Commission (LCSMC) identifies two major watersheds in northeastern Lake County: Kellogg Creek and the Dead River (fig. 5). For management purposes, the LCSMC includes Dead Dog Creek as a subwatershed within the Kellogg Creek Watershed; however, they are hydraulically distinct.

The land-cover statistics for the study area were derived for this investigation by manipulation of the 2001 Multi-Resolution Land Characteristics Consortium National Land Cover Database (NLCD). Land cover in this area was composed of 15 separate categories that were combined into urban, agricultural, and natural. The statistics for the Dead River and Kellogg Creek Watersheds were obtained by creating a mask with the watershed polygons and selecting out those areas from the NLCD. All the $100-\mathrm{ft}$ by $100-\mathrm{ft}$ cells were added to determine the total area per category and then divided by the total area of the polygon to get the percent land cover by category for the watersheds.

\footnotetext{
2 "Dead Dog Creek" is local nomenclature, not currently (2010) recognized by the U.S. Board on Geographic Names.
} 


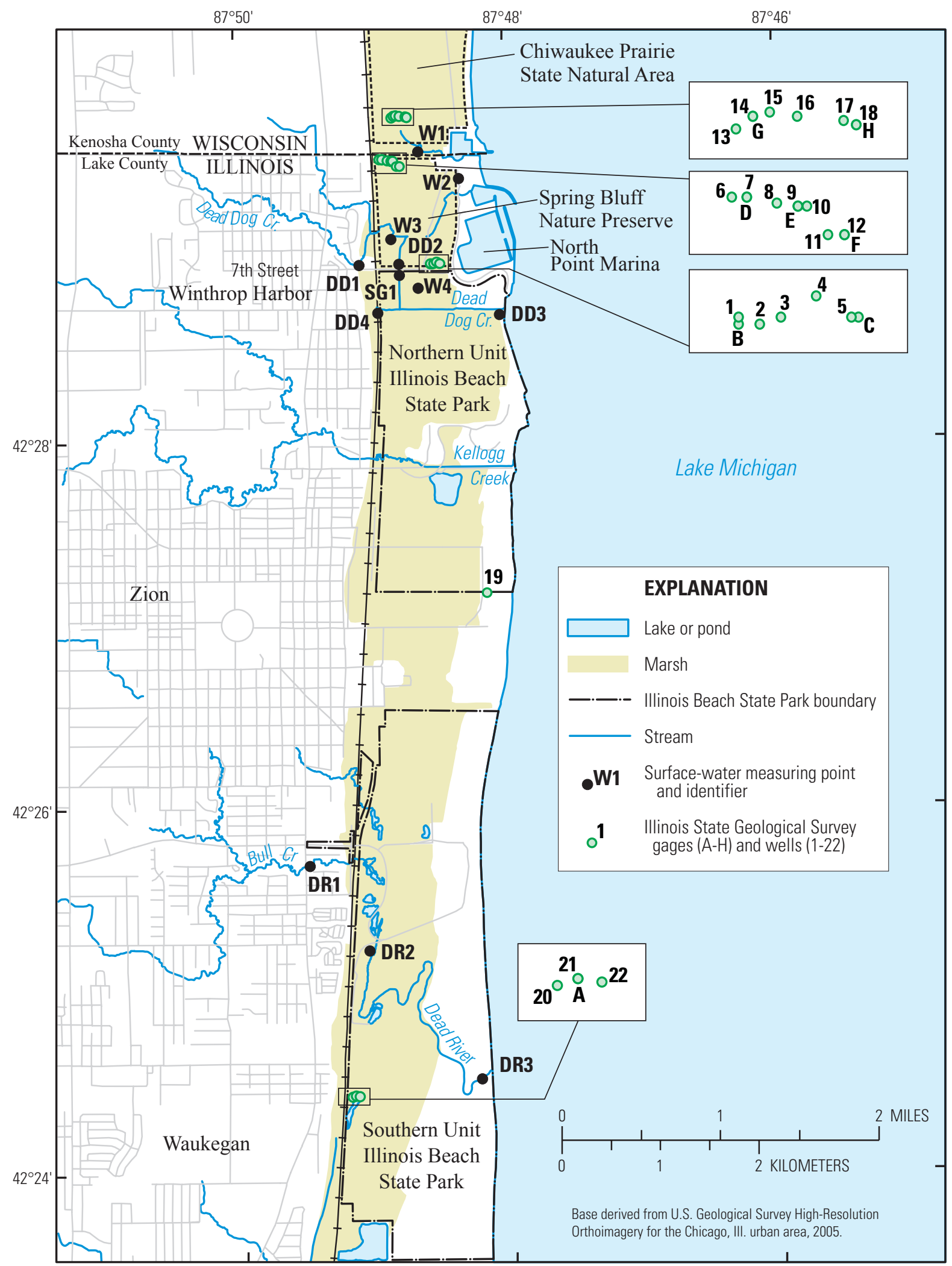

Figure 2. Location of selected surface-water bodies and monitoring points in the vicinity of the Spring Bluff Nature Preserve, Chiwaukee Prairie State Natural Area, and Illinois Beach State Park, near Winthrop Harbor and Waukegan, Illinois. 


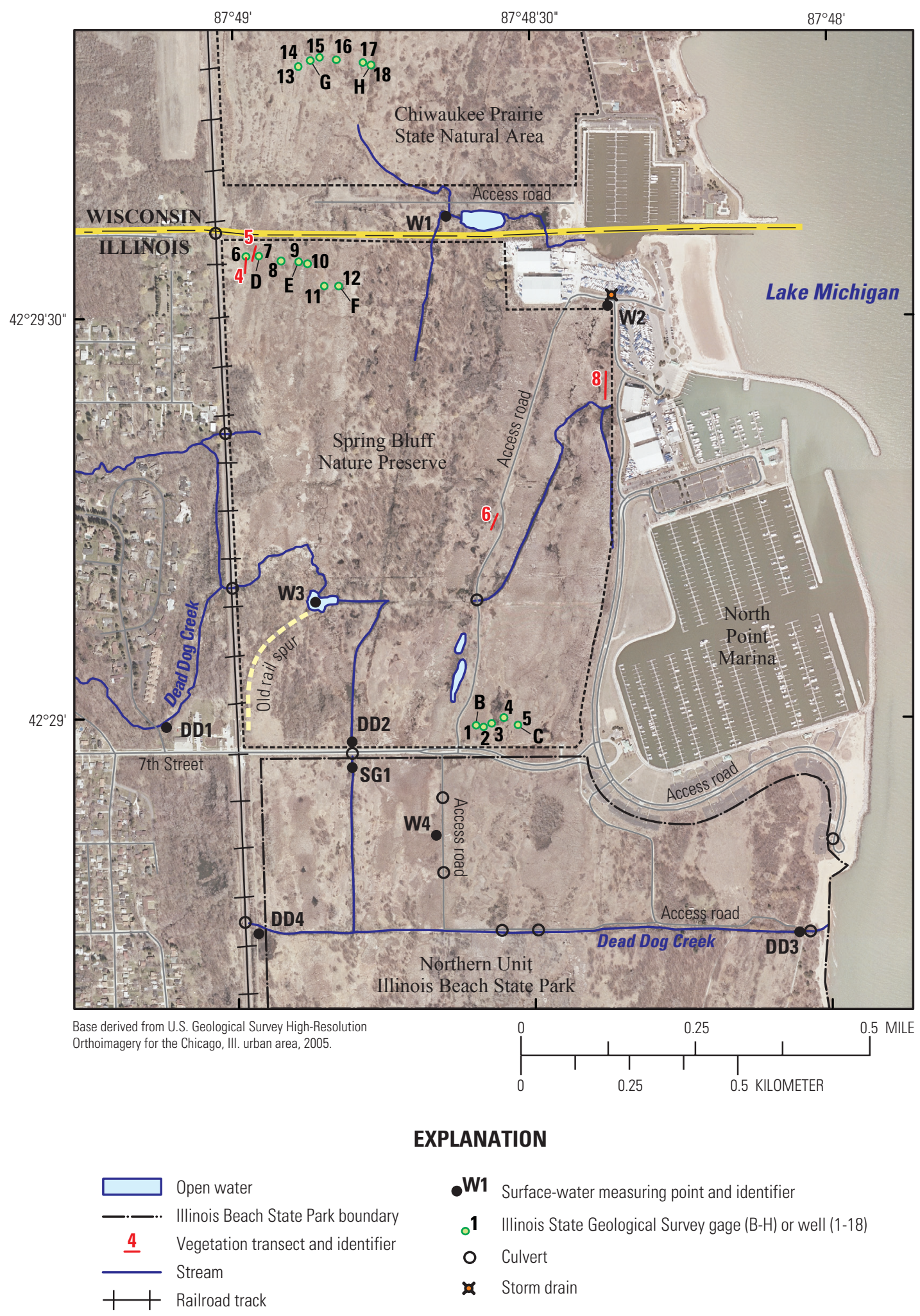

Figure 3. Location of selected features in the vicinity of the Spring Bluff Nature Preserve, Winthrop Harbor, Illinois. 


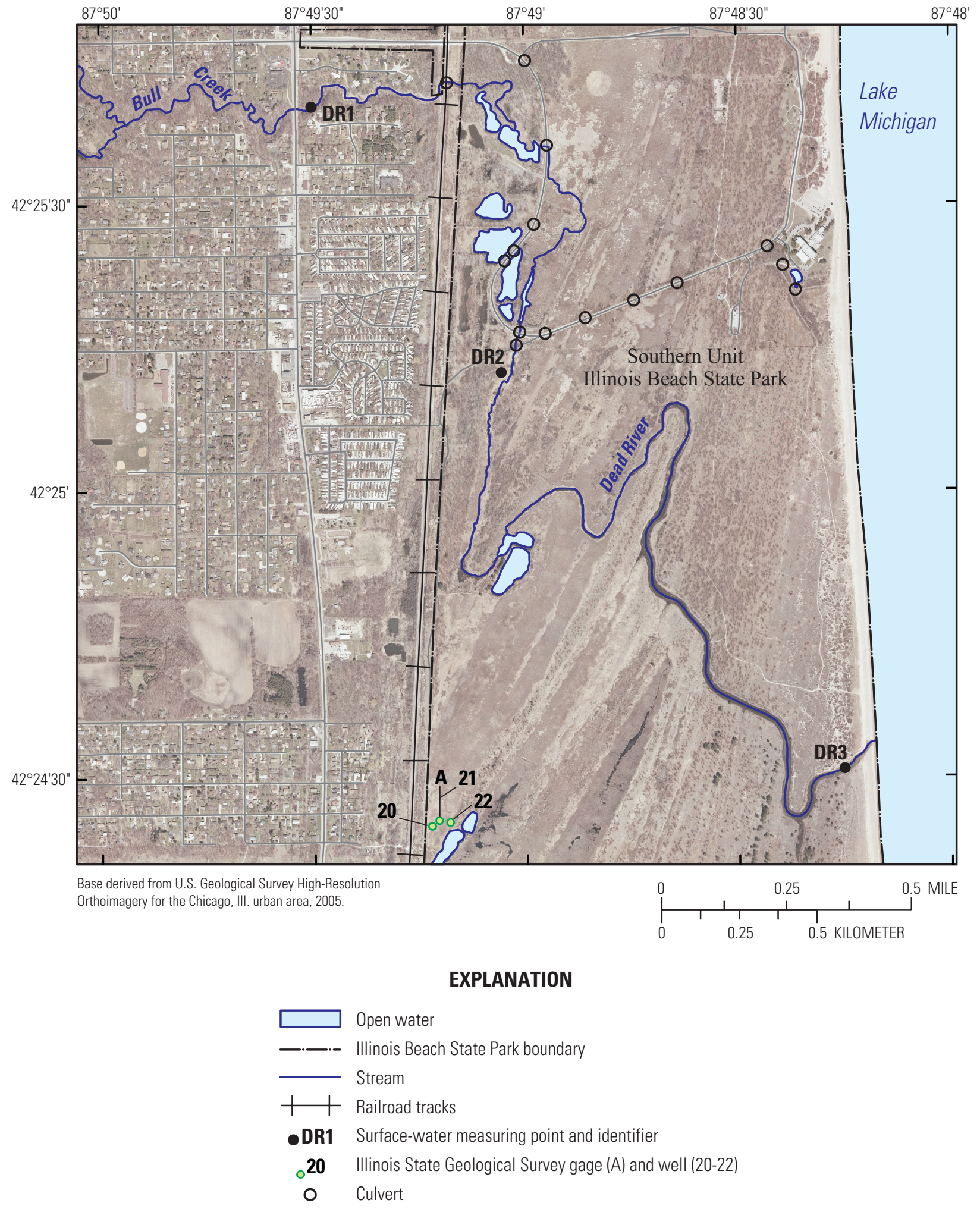

Figure 4. Location of selected features in the vicinity of the Southern Unit of the Illinois Beach State Park near Waukegan, Illinois. 


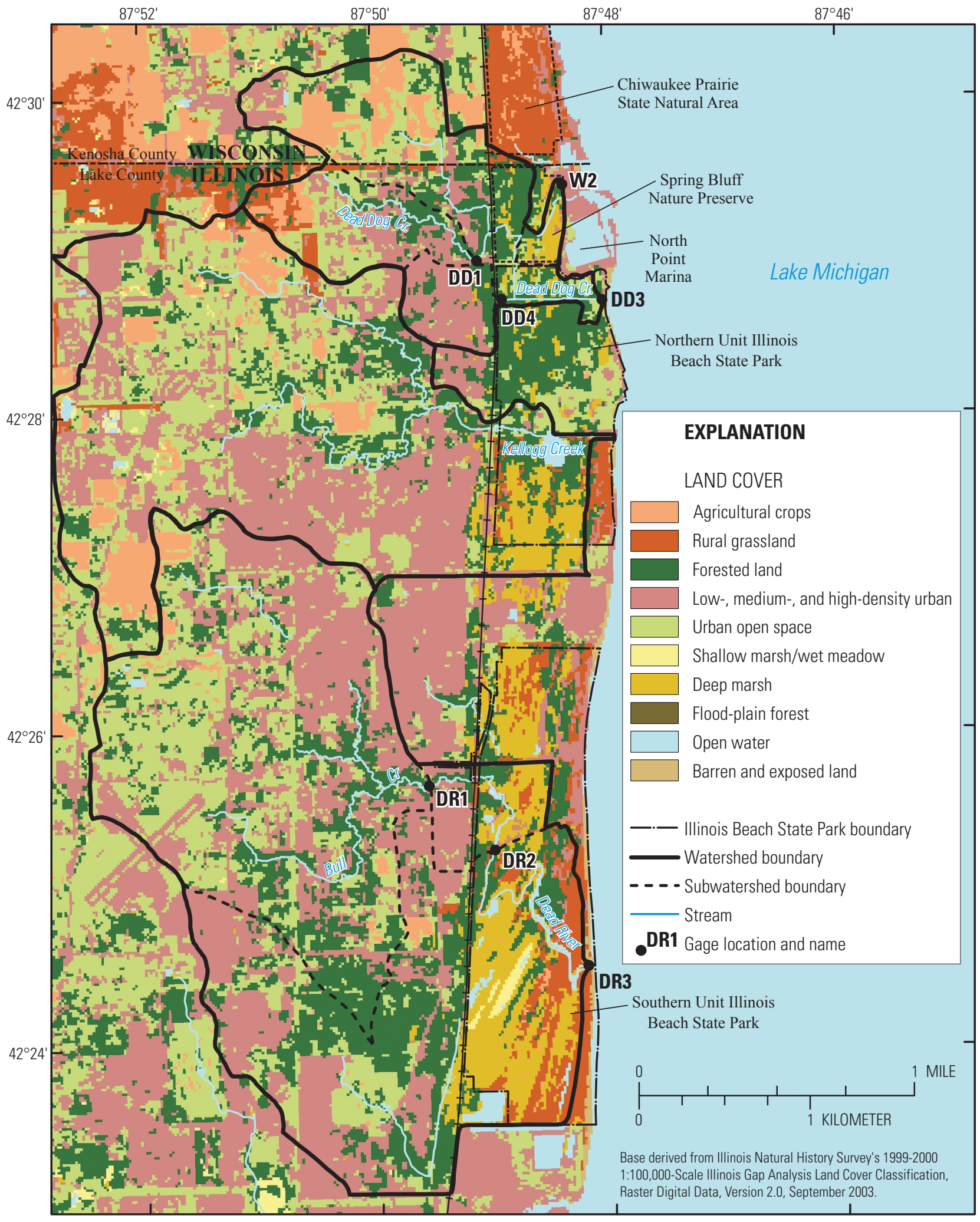

Figure 5. Land cover in the watersheds for Kellogg Creek, Dead Dog Creek, Bull Creek, and the Dead River, northeastern Lake County, Illinois. 


\section{Kellogg Creek and Dead Dog Creek}

The Kellogg Creek Watershed is in northeastern corner of Lake County and extends into southern Wisconsin. The watershed is $11.3 \mathrm{mi}^{2}$, of which Dead Dog Creek drains approximately $2.1 \mathrm{mi}^{2}$ (Lake County Stormwater Management Commission, 2008a). The population within the Kellogg Creek Watershed increased from about 17,500 in 1970 to 24,400 in 2000 , with a projected population of about 35,000 in 2020 (Lake County Stormwater Management Commission, 2008a). The coastal wetland complex accounts for approximately 25 percent of the total watershed area. Agricultural land use accounts for approximately 17 percent of the total watershed area. Residential and other urban land uses account for most of the remainder of land use in the watershed. By 2020 it is expected that land for agricultural and open space uses will be reduced within the watershed and that urban land uses, especially single-family homes, will increase (Lake County Stormwater Management Commission, 2008a).

Kellogg Creek is a straight, channelized creek with high banks that traverses the wetland complex in the NUIBSP (figs. 1 and 5). The banks of Kellogg Creek have been raised by deposition of dredging spoil and other types of fill, so the creek has minimal hydraulic interaction with the surrounding wetland complex and is not included as part of this investigation. The investigation in the northern part of the study area focuses on the Dead Dog Creek part of the watershed.

Dead Dog Creek and smaller intermittent drainages to the north and south drain a predominately urban area to the west of the SBNP, CPSNA, and the NUIBSP (fig. 5). Flow of Dead Dog Creek through the wetland complex in the northern part of the study area is not well defined because of the complex flow through the ditches and culverts as well as through and around the dune and swale topography. However, the general direction of flow is west to east toward gages $\mathrm{W} 1, \mathrm{~W} 2$, and DD3, which is where the watershed drains to Lake Michigan (table 3).

Land use in the Dead Dog Creek Watershed was characterized for areas upstream from gages DD1, DD3, and DD4 (fig. 5) by using geographic information system (GIS) analysis. Gage DD1 is on the bluff approximately $500 \mathrm{ft}$ west of the point where Dead Dog Creek enters the SBNP (figs. 2 and 3; table 3). Gage DD4 is downstream from a storm drain on the eastern side of a culvert beneath the railroad tracks where one of the small ancillary drainages in the Dead Dog Creek Watershed flows into the wetland area on the NUIBSP. Gage DD3 is beside a ditch at the outlet to Lake Michigan. The watershed at gage DD1 has a drainage area of about $1.5 \mathrm{mi}^{2}$. Land use within this part of the watershed is 43 percent agricultural cropland, 31 percent natural (urban open space, park, forest, wetland), and about 26 percent urban land. The watershed upstream from gage DD4 has a drainage area of $0.4 \mathrm{mi}^{2}$. Land use within the watershed for DD4 is about 72 percent urban, with the remaining being natural. The watershed above gage DD3 drains about $3.5 \mathrm{mi}^{2}$. Land use within the watershed for gage DD3 is 37 percent agricultural cropland, about 38 percent natural (about 2 percent is wetland), and about 25 percent urban land.

\section{Bull Creek and Dead River}

The Bull Creek and Dead River Watershed is immediately south of the Kellogg Creek Watershed. A series of ponds and wetlands in the western part of the SUIBSP separates Bull Creek from the Dead River (fig. 4). Bull Creek occupies the upper part of the watershed and the Dead River occupies the lower part. The watershed is $11.0 \mathrm{mi}^{2}$ in area. The population within the watershed increased from about 44,000 in 1970 to about 51,150 in 2000 , with a forecast population of 51,225 in 2020 (Lake County Stormwater Management Commission, 2008b). The coastal complex accounts for $2.9 \mathrm{mi}^{2}$ of the total watershed area. Agricultural land use accounts for approximately 2 percent of the total watershed area. Residential and other urban land uses, including forested urban land and open space, account for approximately 60 percent of the land use in the watershed. By 2020 it is expected that land for agricultural and open space uses will be reduced or eliminated within the watershed and that urban land uses, especially single-family homes, will increase (Lake County Stormwater Management Commission, 2008b).

Bull Creek drains an urbanizing area to the west of the SUIBSP (fig. 5). Bull Creek enters the SUIBSP and flows into a series of man-made ponds and Typha spp.-dominated wetlands, then forms the headwaters of the Dead River near gage DR2. The Dead River meanders through high-quality dune and swale communities until reaching Lake Michigan near gage DR3.

The watershed for Bull Creek was characterized upstream from gage DR1, on the bluff west of the SUIBSP (table 3). The watershed for the Dead River was characterized at gage DR2, downstream from the ponds on the western part of the SUIBSP, and at gage DR3, at the outlet to Lake Michigan (fig. 5). The Bull Creek Watershed above gage DR1 has a drainage area of about $5.7 \mathrm{mi}^{2}$. Land use within the watershed for gage DR1 is about 50 percent urban, about 42 percent natural, and about 8 percent agricultural cropland. The watershed above gage DR2 has a drainage area of $6.2 \mathrm{mi}^{2}$. Land within the watershed for gage DR2 is about 48 percent urban, about 45 percent natural, and about 7 percent agricultural cropland. The watershed above gage DR3 has a drainage area of $11.0 \mathrm{mi}^{2}$. Land use within the watershed for gage DR3 is about 55 percent natural (of which about 2.5 percent is wetland), about 41 percent urban, and 4 percent agricultural cropland. 


\section{Hydrology, Water Quality, and Changes in Vegetation, Spring Bluff Forest Preserve, Illinois, May 2007-August 2008}

Table 3. Gage locations and well locations with associated plant community information in the vicinity of the Spring Bluff Nature Preserve, Chiwaukee Prairie State Natural Area, and Illinois Beach State Park, near Winthrop Harbor and Waukegan, Illinois. Locations of gages and wells are shown in figures 2-4.

[SBNP, Spring Bluff Nature Preserve; NUIBSP, Northern Unit Illinois Beach State Park; na, not assigned; CPSNA, Chiwaukee Prairie Natural Area; SUIBSP, Southern Unit Illinois Beach State Park]

\begin{tabular}{|c|c|c|}
\hline $\begin{array}{l}\text { Staff } \\
\text { gage }\end{array}$ & $\begin{array}{l}\text { U.S. Geological Survey } \\
\text { station number }\end{array}$ & Hydrologic overview \\
\hline DD1 & 4087300 & $\begin{array}{l}\text { In main channel of Dead Dog Creek near base of bluff about } 300 \text { feet west of SBNP. Water flows } \\
\text { into SBNP. }\end{array}$ \\
\hline DD2 & 4087316 & $\begin{array}{l}\text { In ditch at culvert in wetland area immediately north of } 7 \text { th Street in SBNP. Water typically stag- } \\
\text { nant. Can flow south if water is high. }\end{array}$ \\
\hline DD4 & 4087318 & Located at railroad culvert downstream of storm drain. Water flows to the NUIBSP. \\
\hline SG1 & na & $\begin{array}{l}\text { In ditch in wetland area immediately south of } 7 \text { th Street in NUIBSP. Water typically stagnant. Can } \\
\text { flow south if water is high. }\end{array}$ \\
\hline W3 & 4087312 & $\begin{array}{l}\text { In western part of SBNP in pond surrounded by wetland. Water typically stagnant but can flow to } \\
\text { east and north. }\end{array}$ \\
\hline W4 & 4087317 & In northern part of NUIBSP in wetland. Water typically stagnant. \\
\hline DR1 & 4087405 & $\begin{array}{l}\text { In main channel of Bull Creek near top of bluff about 1,000 feet west of SUIBSP. Water flows into } \\
\text { SUIBSP. }\end{array}$ \\
\hline DR2 & 40874083 & $\begin{array}{l}\text { In main channel of Dead River at culvert near bend in road in wetland area downstream of } \\
\text { retention ponds. Water typically stagnant, but flow toward Lake Michigan. }\end{array}$ \\
\hline $\mathrm{C}$ & na & In SBNP in emergent marsh adjacent to well 5. \\
\hline $\mathrm{D}$ & na & In SBNP in emergent marsh adjacent to well 7. \\
\hline $\mathrm{E}$ & na & In SBNP in emergent marsh adjacent to well 9. \\
\hline $\mathrm{F}$ & na & In SBNP in emergent marsh adjacent to well 12. \\
\hline G & na & In CPSNA in sedge meadow adjacent to well 14 . \\
\hline $\mathrm{H}$ & na & In CPSNA in emergent marsh adjacent to well 18. \\
\hline
\end{tabular}


Table 3. Gage locations and well locations with associated plant community information in the vicinity of the Spring Bluff Nature Preserve, Chiwaukee Prairie State Natural Area, and Illinois Beach State Park, near Winthrop Harbor and Waukegan, Illinois. Locations of gages and wells are shown in figures $2-4$. -Continued

[SBNP, Spring Bluff Nature Preserve; NUIBSP, Northern Unit Illinois Beach State Park; na, not assigned; CPSNA, Chiwaukee Prairie Natural Area; SUIBSP, Southern Unit Illinois Beach State Park]

\begin{tabular}{ccl}
\hline Well & $\begin{array}{c}\text { U.S. Geological Survey } \\
\text { station number }\end{array}$ & \multicolumn{1}{c}{ Hydrologic overview } \\
\hline 1 & na & In SBNP in emergent marsh. \\
2 & na & In SBNP in mesic prairie. \\
3 & na & In SBNP in emergent marsh. \\
4 & na & In SBNP in mesic prairie. \\
5 & na & In SBNP in emergent marsh. \\
6 & na & In SBNP in wet prairie. \\
7 & na & In SBNP in emergent marsh. \\
8 & na & In SBNP in wet-mesic prairie. \\
9 & na & In SBNP in emergent marsh. \\
10 & na & In SBNP in wet prairie. \\
11 & na & In SBNP in wet-mesic prairie. \\
12 & na & In SBNP in emergent marsh. \\
13 & na & In CPSNA in mesic prairie. \\
14 & na & In CPSNA in sedge meadow. \\
15 & na & In CPSNA in mesic prairie. \\
16 & na & In CPSNA in wet prairie. \\
17 & na & In CPSNA in mesic prairie. \\
18 & na & In CPSNA in emergent marsh. \\
19 & na & In NUIBSP in panne. \\
20 & na & In SUIBSP in wet prairie. \\
21 & na & In SUIBSP in sedge meadow. \\
22 & na & In SUIBSP in wet prairie. \\
\hline & & \\
\hline
\end{tabular}

\section{Meteorological Data}

Temperature and precipitation were measured at a weather station in Kenosha, Wis. (station 474174), maintained by the National Oceanic and Atmospheric Administration. This station is approximately $6 \mathrm{mi}$ north of the study area and is the closest weather station with a lakeshore setting that is similar to the study area. The actual data for this station were obtained from the Midwestern Regional Climate Center (Midwestern Regional Climate Center, 2008). Normal precipitation values and the above-normal and below-normal range thresholds at this station were calculated by the National Water and Climate Center (National Water and Climate Center, 2008) on the basis of 1971-2000 data (National Water and Climate Center, 1995). Conditions at Kenosha are assumed to be representative of the study area.

Monthly precipitation during the investigation ranged from 0.69 in. during November 2007 to 11.50 in. during August 2007 (table 4). Precipitation totals during the period of investigation were more than 7 in. above the mean. Most of this excess precipitation occurred in August 2007, when precipitation was more than 7 in. greater than normal. Precipitation data indicate hydraulic conditions during the investigation were wetter than average, further indicating that water levels and chemical and sediment loads during the investigation may have been higher than typical.

Mean monthly temperature at the Kenosha station during the investigation ranged from $22.5^{\circ} \mathrm{C}$ during August 2007 to $-5.28^{\circ} \mathrm{C}$ during February 2008 (table 4). Mean temperatures during the investigation were somewhat higher than typical, implying that evapotranspiration during the investigation also may have been higher than typical.

The date of first autumnal $-2.2^{\circ} \mathrm{C}$ measurement during the investigation was November 15, 2007. The date of last vernal $-2.2^{\circ} \mathrm{C}$ during the investigation was March 30,2008 . These dates approximate the period when there was no plant growth during the investigation. The remainder of the period of investigation approximates the growing season, when plant growth can result in evapotranspiration and nutrient uptake. 
Table 4. Climate data, May 2007-August 2008, Kenosha, Wisconsin.

[Data from Midwest Regional Climate Center, 2008; -, less than normal; +, more than normal]

\begin{tabular}{|c|c|c|c|c|}
\hline Month and year & $\begin{array}{l}\text { Total precipitation } \\
\text { (inches) }\end{array}$ & $\begin{array}{l}\text { Departure from } \\
\text { normal (inches) }\end{array}$ & $\begin{array}{l}\text { Mean temperature } \\
\text { during investigation } \\
\text { (degrees Celsius) }\end{array}$ & $\begin{array}{l}\text { Departure from normal } \\
\text { (degrees Celsius) }\end{array}$ \\
\hline June 2007 & 3.24 & -.35 & 19.61 & 1.83 \\
\hline July 2007 & 3.81 & .13 & 22.17 & .78 \\
\hline October 2007 & 2.82 & .35 & 14.17 & 3.44 \\
\hline November 2007 & .69 & -1.99 & 4.17 & .44 \\
\hline December 2007 & 3.77 & 1.68 & -2.39 & .50 \\
\hline January 2008 & 1.70 & .03 & -4.61 & 1.39 \\
\hline May 2008 & 2.62 & -.75 & 11.39 & -.94 \\
\hline June 2008 & 5.29 & 1.70 & 19.06 & 1.28 \\
\hline July 2008 & 5.16 & 1.48 & 21.83 & .44 \\
\hline August 2008 & 1.09 & -3.10 & 21.78 & .78 \\
\hline $\begin{array}{l}\text { Total, May } 2007 \text { through } \\
\text { August } 2008\end{array}$ & 57.18 & 7.64 & Not applicable & Not applicable \\
\hline
\end{tabular}

\section{Topography}

The primary surface features in the study area are the bluff in the western part of the study area, the dune and swale topography from the bluff eastward toward Lake Michigan, and the beach topography at the lakeshore (figs. 6 and 7). Roadbed for the train tracks at the base of the bluff near the western edge of the wetland complex also forms a small topographic ridge throughout the study area.

In the northern part of the study area in the vicinity of the SBNP, CPSNA, and the NUIBSP, the elevation of the land surface in the upland area near the top of the bluff exceeds $610 \mathrm{ft}$ (all elevations relative to North American Vertical Datum of 1988 (NAVD 88)), whereas the elevation of the railroad tracks is about $600 \mathrm{ft}$ (fig. 6). Land-surface elevation near the lakeshore ranges from about $577 \mathrm{ft}$ near the 2007 shoreline (http://www.in.gov/dnr_old/water/lake_michigan/ coastal/pdf/03WaterLevelTable1981-2008LakeMichigan.pdf, accessed May 7, 2009) to about $596 \mathrm{ft}$ at the parking lots south of the North Point Marina. Land-surface elevation in the wetland complex in the northern part of the study area between the bluff and the shoreline ranges from 585 to $590 \mathrm{ft}$. The low points (about $585 \mathrm{ft}$ ) are in the ditches and interdunal swales. High points are on the ridges and dunes in the upland prairie and savanna communities. Additionally, locally higher elevation is associated with several man-made features in the northern part of the study area, including 7th Street, the offshoot from the railroad near the southwestern edge of the SBNP, the marina roads and parking lots at the eastern edge of the SBNP, the access road running north-south through the eastern part of the SBNP, a man-made berm between the CPSNA and the SBNP, and north-south-running grass roads in the western and central parts of the NUIBSP.

In the southern part of the study area west of the SUIBSP, land-surface elevation near the top of the bluff is higher than $620 \mathrm{ft}$ (fig. 7). Land surface in most of the SUIBSP ranges from 582 to $590 \mathrm{ft}$ and along the railroad tracks is about $596 \mathrm{ft}$. Elevation near the lakeshore at the SUIBSP ranges from about $577 \mathrm{ft}$ near the 2007 shoreline to about $590 \mathrm{ft}$ at the top of the dunes adjacent to the lake. Similar to the north part of the study area, lower points are commonly interdunal wetlands and ditches, and high points are commonly prairie and savanna communities on sand ridges. 


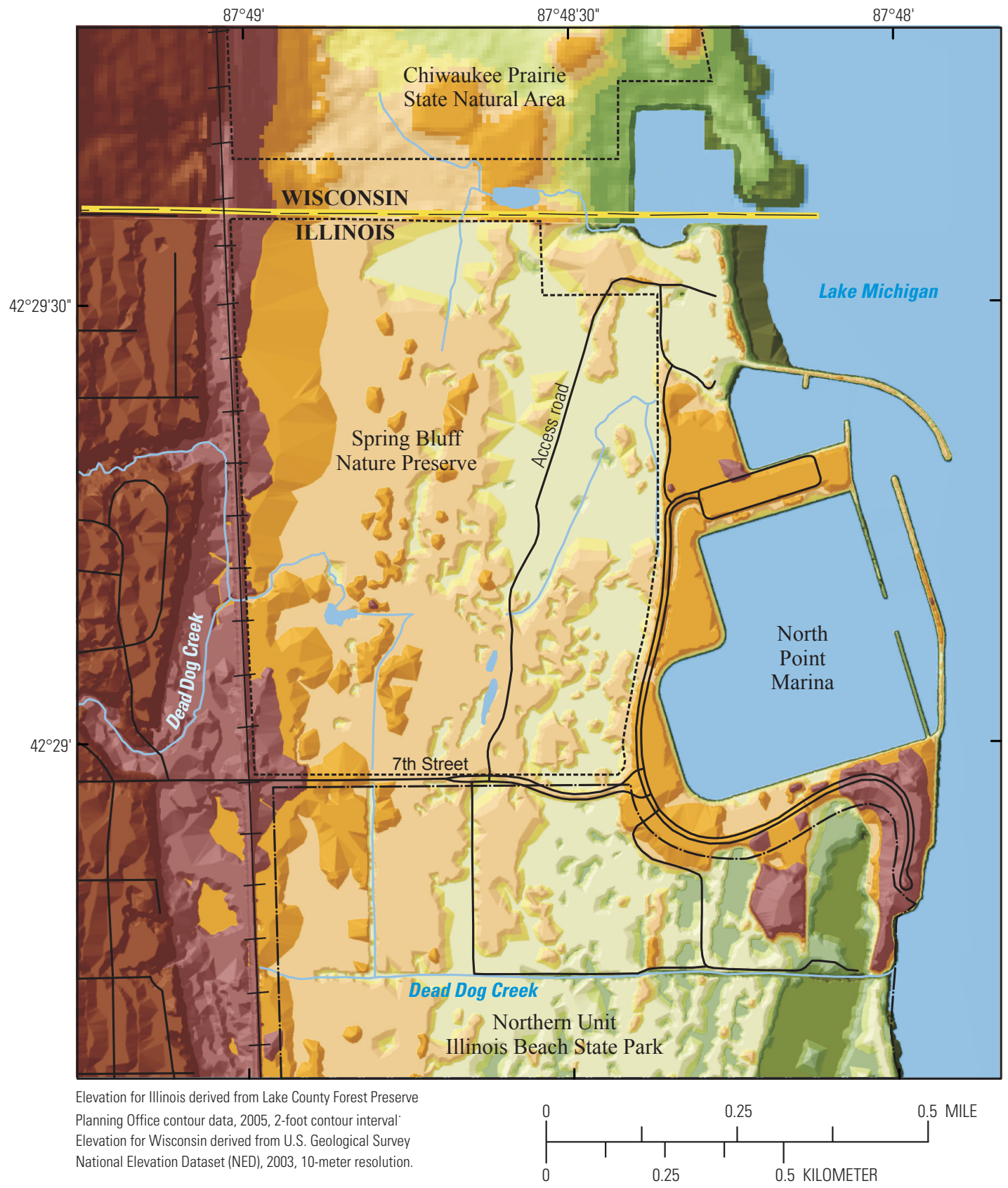

\section{EXPLANATION}

Elevation, in feet above North American Vertical Datum of 1988

\begin{tabular}{|l|l|}
\hline Water & 585 to 586 \\
\hline 577 to 581 & 586 to 587 \\
\hline 581 to 582 & 587 to 588 \\
\hline 582 to 583 & 588 to 590 \\
\hline 583 to 584 & 590 to 600 \\
\hline 584 to 585 & Over 600 \\
\hline
\end{tabular}

Figure 6. Topography in the vicinity of the Spring Bluff Nature Preserve, Winthrop Harbor, Illinois. 


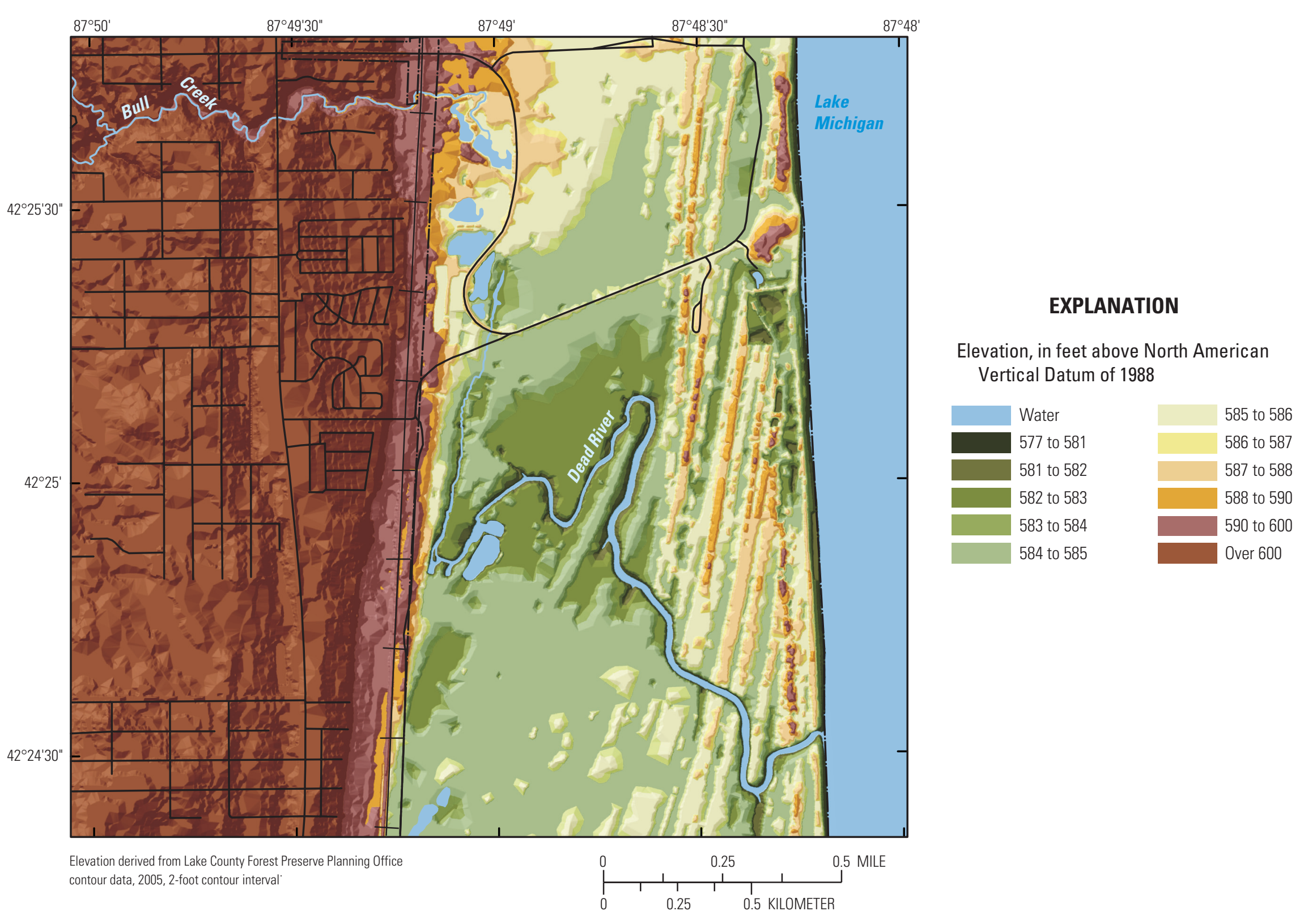

Figure 7. Topography in the vicinity of the Southern Unit of the Illinois Beach State Park near Waukegan, Illinois. 


\section{Methods of Investigation}

\section{Water-Level Measurement}

Surface-water levels were measured periodically using USGS staff gages at locations DD1, DD2, W1, W2, W3, W4, DR1, DR2, and DR3; and ISGS staff gages installed at locations A-H (table 5; figs. 2, 3, and 4). Staff gages were bolted to metal posts, which were driven a minimum of $2 \mathrm{ft}$ into the sediment. Surface-water levels were measured periodically from a fixed point of reference at locations DD3, DD4, and SG1 by use of an electric water-level indicator (electric tape measure). Staff gages and electric water-level indicators were calibrated to $0.01 \mathrm{ft}$. For the purposes of this report "gage" refers to any location where surface-water levels were measured, whereas "staff gage" refers to the device used to measure surface-water levels at many of the gages.

Surface-water levels were measured every 15 minutes during May 24-November 1, 2007, and during March 18June 11, 2008, at gages DD1, DD2, W1, W3, W4, and DR2 by use of a pressure transducer and water-level logger. Surface-water levels also were measured every 15 minutes during May 24-November 1, 2007, at gage W2. Gage W2 was submerged during the spring of 2008, so a water-level logger could not be reinstalled during this period. The transducers were securely affixed to the metal post that held the staff gages and were periodically serviced to reduce fouling. Transducers were capable of detecting changes in water level of $0.015 \mathrm{ft}$. Water levels measured by the pressure transducers were compared to periodic readings from the staff gage to verify the accuracy of the transducer data.

Groundwater levels were measured in shallow monitoring wells 1-22 during July 2007-August 2008. These wells were designed to monitor the zone of saturation in the near-surface sediments, according to the methods of Miner and Simon (1997). Eighteen wells were installed along three transects in the CPSNA and the SBNP (fig. 3), one well at a location in the NUIBSP and three wells along one transect in the SUIBSP (fig. 4). Locations for well installation were chosen to represent the range of wetland and non-wetland plant communities in the sites and to include areas with native and nonnative vegetation for comparison. Transects were oriented west to east and generally perpendicular to the orientation of dune ridges and interdunal swales, thereby intersecting as many different vegetation communities as possible. This approach allowed comparison of hydroperiod and floristic composition and quality in areas of greater or lesser dominance by Typha spp. and Phragmites australis. Well 19 was installed in the NUIBSP in a high-quality panne to document hydrologic conditions in that globally rare wetland type. All wells were constructed with threaded 2-in. PVC casing and 0.01-in. slotted manufactured PVC screens that were 1-ft long. Wells were generally installed to a depth of $2.5 \mathrm{ft}$, with wells in topographically higher positions $(2,4$, and 17$)$ being installed slightly deeper to ensure they reached depths with soil-zone saturation. All screens were fitted with a bottom cap with a drainage hole. The annulus between the well screen and soil was packed with quartz sand with a grain size of 0.038 in., and the remainder of the annulus was then backfilled to land surface with medium bentonite chips. The minimum length of the annular seal was $1 \mathrm{ft}$.

Groundwater levels were measured by using an electronic water-level measuring tape approximately every 2 to 4 weeks. In addition, pressure transducers and dataloggers were installed in July 2007 in wells 1, 3, 5, 6, 7, 9, 12, 14, 16, 18,19 , and 21 . The dataloggers recorded water levels every 6 hours to an accuracy of $0.01 \mathrm{ft}$ through August 2008 .

\section{Surveying}

The locations of all USGS surface-water gages were surveyed by using a hand-held global positioning system (GPS) unit to a horizontal accuracy of about $3 \mathrm{ft}$ and reported as latitude and longitude. The elevation of the reference point for gages DD3 and SG1 and a reference point on the staff gages was surveyed to $0.01 \mathrm{ft}$ by using rod and level techniques. Staff gages were surveyed in June 2007 and resurveyed in May 2008 to ensure that the gage reading could be corrected, if necessary, for movement during the winter. All elevations were referenced to NAVD 88.

ISGS gage and well locations were determined by using a GPS unit and were differentially corrected to an accuracy of $1 \mathrm{ft}$. Instrument elevations were determined with either optical level or total station to an accuracy of $0.01 \mathrm{ft}$. Onsite elevation control was tied to benchmarks set by LCFPD personnel.

\section{Surface-Water Discharge}

In addition to the continuous measurement of stage, stream discharge was measured periodically (table 5) at gages DD1, W1, DD3, DD4, DR1, DR2, and DR3 according to standard USGS methods (Rantz and others, 1982). In general, these methods include the measurement of stream depth and stream velocity at 20 or more vertical sections across the stream; stream discharge is then computed from these measurements. 
Table 5. Information on gages and wells in the vicinity of the Spring Bluff Nature Preserve, Chiwaukee Prairie State Natural Area, and Illinois Beach State Park, near Winthrop Harbor and Waukegan, Illinois. Locations of wells and gages are shown in figures 2-4.

[na, not assigned]

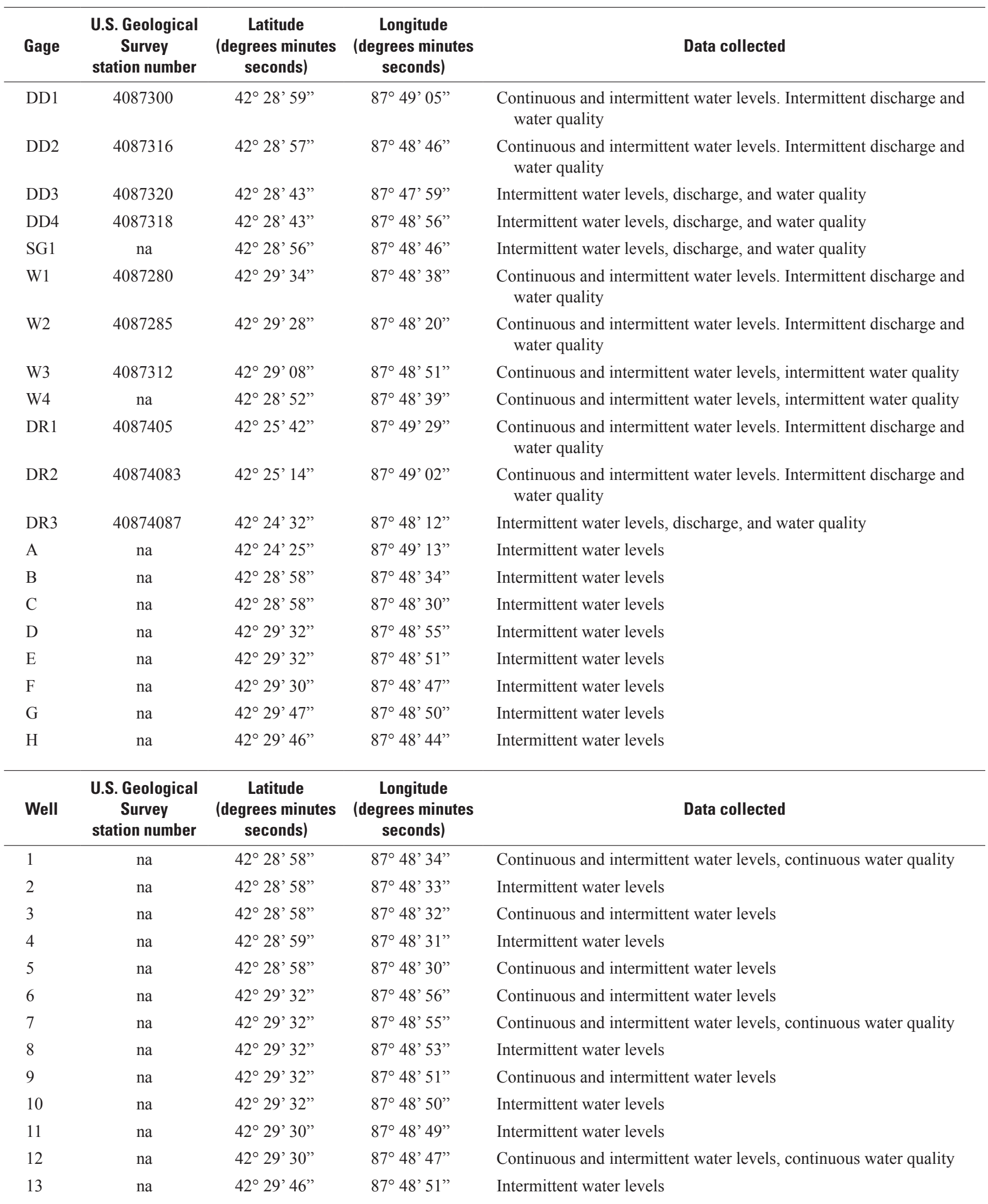


Table 5. Information on gages and wells in the vicinity of the Spring Bluff Nature Preserve, Chiwaukee Prairie State Natural Area, and Illinois Beach State Park, near Winthrop Harbor and Waukegan, Illinois. Locations of wells and gages are shown in figures 2-4. -Continued

\begin{tabular}{ccccl} 
[na, not assigned] & & & \\
\hline Well & $\begin{array}{c}\text { U.S. Geological } \\
\text { Survey } \\
\text { station number }\end{array}$ & $\begin{array}{c}\text { Latitude } \\
\text { (degrees minutes } \\
\text { seconds) }\end{array}$ & $\begin{array}{c}\text { Longitude } \\
\text { (degrees minutes } \\
\text { seconds) }\end{array}$ & \multicolumn{1}{c}{ Data collected } \\
\hline 14 & na & $42^{\circ} 29^{\prime} 47^{\prime \prime}$ & $87^{\circ} 48^{\prime} 50^{\prime \prime}$ & Continuous and intermittent water levels \\
15 & na & $42^{\circ} 29^{\prime} 47^{\prime \prime}$ & $87^{\circ} 48^{\prime} 49^{\prime \prime}$ & Intermittent water levels \\
16 & na & $42^{\circ} 29^{\prime} 47^{\prime \prime}$ & $87^{\circ} 48^{\prime} 47^{\prime \prime}$ & Continuous and intermittent water levels \\
17 & na & $42^{\circ} 29^{\prime} 46^{\prime \prime}$ & $87^{\circ} 48^{\prime} 45^{\prime \prime}$ & Intermittent water levels \\
18 & na & $42^{\circ} 29^{\prime} 46^{\prime \prime}$ & $87^{\circ} 48^{\prime} 44^{\prime \prime}$ & Continuous and intermittent water levels, continuous water quality \\
19 & na & $42^{\circ} 27^{\prime} 10^{\prime \prime}$ & $87^{\circ} 48^{\prime} 10^{\prime \prime}$ & Continuous and intermittent water levels \\
20 & na & $42^{\circ} 24^{\prime} 24^{\prime \prime}$ & $87^{\circ} 49^{\prime} 15^{\prime \prime}$ & Intermittent water levels \\
21 & na & $42^{\circ} 24^{\prime} 25^{\prime}$, & $87^{\circ} 49^{\prime} 13^{\prime \prime}$ & Continuous and intermittent water levels \\
22 & na & $42^{\circ} 24^{\prime} 25^{\prime \prime}$ & $87^{\circ} 49^{\prime} 12^{\prime \prime}$ & Intermittent water levels \\
\hline
\end{tabular}

\section{Water-Quality Sampling}

Surface-water samples were collected periodically at gages DD1, DD3, DD4, W1, W3, W4, DR1, DR2, and DR3. For the purposes of this report, periodic sampling refers to the intermittent water-quality sampling activities on May 31 , June 27, July 30, August 29, September 18, and November 27, 2007, as well as on April 2 and May 15, 2008. Dissolved oxygen, specific conductance, $\mathrm{pH}$, and temperature (referred to hereafter as "field parameters") were measured (when possible) during periodic sampling prior to sample collection with a calibrated multiparameter water-quality measuring instrument according to USGS protocols (Wilde and others, 1998). Samples collected during periodic sampling were analyzed for concentrations of suspended sediment, dissolved nitrate plus nitrite (as nitrogen) (Fishman and Friedman, 1989), dissolved phosphorous (according to U.S. Environmental Protection Agency method 365.1), and dissolved chloride (Fishman and Friedman, 1989; table 5). Depth-integrated samples were collected from a single point in the stream or wetland. Samples to be analyzed for dissolved nitrate plus nitrite, dissolved phosphorous, and dissolved chloride were filtered through a $0.45-\mu \mathrm{m}$ filter prior to preservation with ice and shipment. Concentrations of dissolved nitrate plus nitrite, dissolved phosphorous, and dissolved chloride were determined by the USGS National Water Quality Laboratory in Denver, Colo. Samples to be analyzed for dissolved nitrate plus nitrite, dissolved phosphorous, and dissolved chloride (hereafter referred to as "chloride") were shipped to the laboratory for analysis within 24 hours of collection and were analyzed within accepted holding times.

In addition to the periodic sampling, suspended-sediment samples were collected at gages DD1 or DR1 before, during, and after selected storm events. These storm-event samples were collected by an automatic sampler at intervals of 30 to 180 minutes as programmed by the person operating the sampler. Storm-event samples were collected from other gages during some of these events.

Suspended-sediment concentrations were determined by the USGS Sediment Laboratory in Louisville, Ky., in accordance with the lab's standard operating procedures (Shreve and Downs, 2005). Samples to be analyzed for suspended-sediment concentration were covered to protect them from light and were analyzed within 12 months of collection.

Duplicate samples were collected to determine the variability of field collection and laboratory analyses. Comparisons of concentrations from samples and their field duplicates show close agreement, indicating an acceptable level of variability from collection and laboratory practices

In addition to periodic and storm-event sampling, continuous measurements of surface-water quality were collected using multiparameter water-quality sensors and dataloggers. Multiparameter water-quality instruments were used to measure specific conductance and temperature of surface water adjacent to (outside of) wells 1, 7, 12, 18, and 21 every 6 hours during October 2007-July 2008. Multiparameter instruments were used to measure the turbidity, specific conductance, and temperature of surface water every 6 hours at gages W1, DD1, and W3 for part or all of the period between October 2007 and July 2008. Multiparameter instruments were serviced approximately every 2 months and recalibrated. Incorrect readings that resulted when the instruments were dry, frozen, or otherwise malfunctioning were removed according to procedures in Wagner and others (2000). The sensors on the instruments were deployed approximately at land surface to measure the quality of surface water rather than groundwater. 


\section{Vegetation Monitoring}

Vegetation was monitored within eight $10.76-\mathrm{ft}^{2}$ quadrats near each monitoring well (1-22) for species presence and abundance. Abundance was measured by a visual estimate of absolute percent cover of plants rooted within the quadrat. The abundance of two invasive species of particular interest, Typha spp. and Phragmites australis, were measured by counting the number of rooted individuals within each quadrat. Because hybridization between Typha angustifolia and T. latifolia has been observed (Smith, 1967), and because genetic studies indicate that morphological characteristics are not good indicators for identification of Typha spp. because of the variability found in hybrids (Marburger and others, 2005), all Typha species were lumped into Typha spp. for this investigation.

At each well, quadrats were positioned at 6.5 and $13 \mathrm{ft}$ from the well in each cardinal direction for a total of eight quadrats sampled near each well. The 6.5 -ft radius from the well avoided areas of disturbance adjacent to the well but kept quadrats close enough to the well to be representative. If there was a change in topography within $13 \mathrm{ft}$ of the well that resulted in a distinct change of community type, quadrats were repositioned in a different cardinal direction at 20 or $26 \mathrm{ft}$ from the well to prevent sampling in a community type that was not representative of the well vicinity. Wells 6-12 were sampled on August 28, 2007 (prior to the start of management to control Typha spp. in the surrounding area), and wells 1-5 and 12-22 were sampled on June 30 and July 1, 2008.

Data collected from the quadrats were entered into the Floristic Quality Assessment and Computer Applications program (Swink and Wilhelm, 1994; Wilhelm and Masters, 2006) and the Species Richness Indices Spreadsheet Program for Graminoid and Herbaceous Plant Communities (Bowles and Jones, 2007) to quantify species richness per quadrat, average wetness, mean coefficient of conservatism (all species and native only), species richness index (all species and native only), density of Typha spp. per quadrat, density of Phragmites australis per quadrat, and total species richness of all eight quadrats sampled per well. Classification of communities was based on the Chicago Wilderness Community Classification (Chicago Wilderness, 1999) and determined by floristic composition and average wetness.

To explore the relations between hydrological and biological conditions in a quantitative manner, a correlation matrix was constructed for selected parameters. Pearson correlation coefficients $\left(\mathrm{R}^{2}\right)$ were calculated for various data subsets; an $\mathrm{R}^{2}$ value exceeding 0.70 was considered to show a high degree of correlation. Biological data sets (Typha spp. relative importance, Phragmites australis relative importance, mean vegetative wetness, native species mean coefficient of conservatism, and native species richness index) were calculated from vegetation-monitoring data. For land-surface elevations, the 2007 survey data were used. The rest of the data (mean depth-to-water, growing season mean depth-to-water, days of inundation, and growing season days of inundation) were derived from manual and datalogger water-level measurements. For wells where continuous water-level measurements were available, total days of surface inundation were calculated. For wells without continuous data, total days of inundation were calculated by interpolating between manual waterlevel measurements. Data from nearby continuous recorders were used to constrain the timing of wetting and drying events in the interpolation. Plant growth and soil microbial activity (which creates the anaerobic conditions favoring plants adapted to wetter conditions) are both affected by soil temperatures (Mitsch and Gosselink, 2007). For this reason, mean depth-to-water and days of inundation were estimated for the growing-season period as well as for the entire monitoring period. The growing-season dates were based on climate data from the Kenosha, Wis., station (National Water and Climate Center, 2008).

\section{Surface-Water Hydrology}

The hydrology of the creeks and wetlands in the study area is affected by the timing and amount of precipitation, evapotranspiration, the amount of flow into and out of the study area, interaction between surface water and groundwater, stage of Lake Michigan, and a variety of other factors (Visocky, 1976; Kubillus, 1994).

\section{Water Levels Through Time}

Water levels collected at gages DD1 (fig. 8) and W1 (fig. 9) demonstrate that surface-water levels in and near the wetland complex vary in response to meteorologic events (primarily precipitation, snowmelt, and evapotranspiration). These phenomena can affect water levels over periods of hours to months.

Seasonal variations in meteorologic conditions (primarily variations in precipitation and temperature) had the greatest affect on surface-water levels during the investigation. Typically, precipitation in Illinois is highest in spring through summer, peaking in late spring to early summer. Evapotranspiration is highest in summer and greatly reduces overland runoff and infiltration to groundwater (Hensel, 1992). Therefore, water levels in streams and wetlands are typically highest during spring, decline during summer and fall, and begin rising in winter through spring. This is the pattern observed in the wetlands and streams in the study area (figs. 8 and 9), where water levels declined overall from the start of monitoring in May 2007 through early August 2007 in response to reduced runoff from precipitation and increased evapotranspiration. 


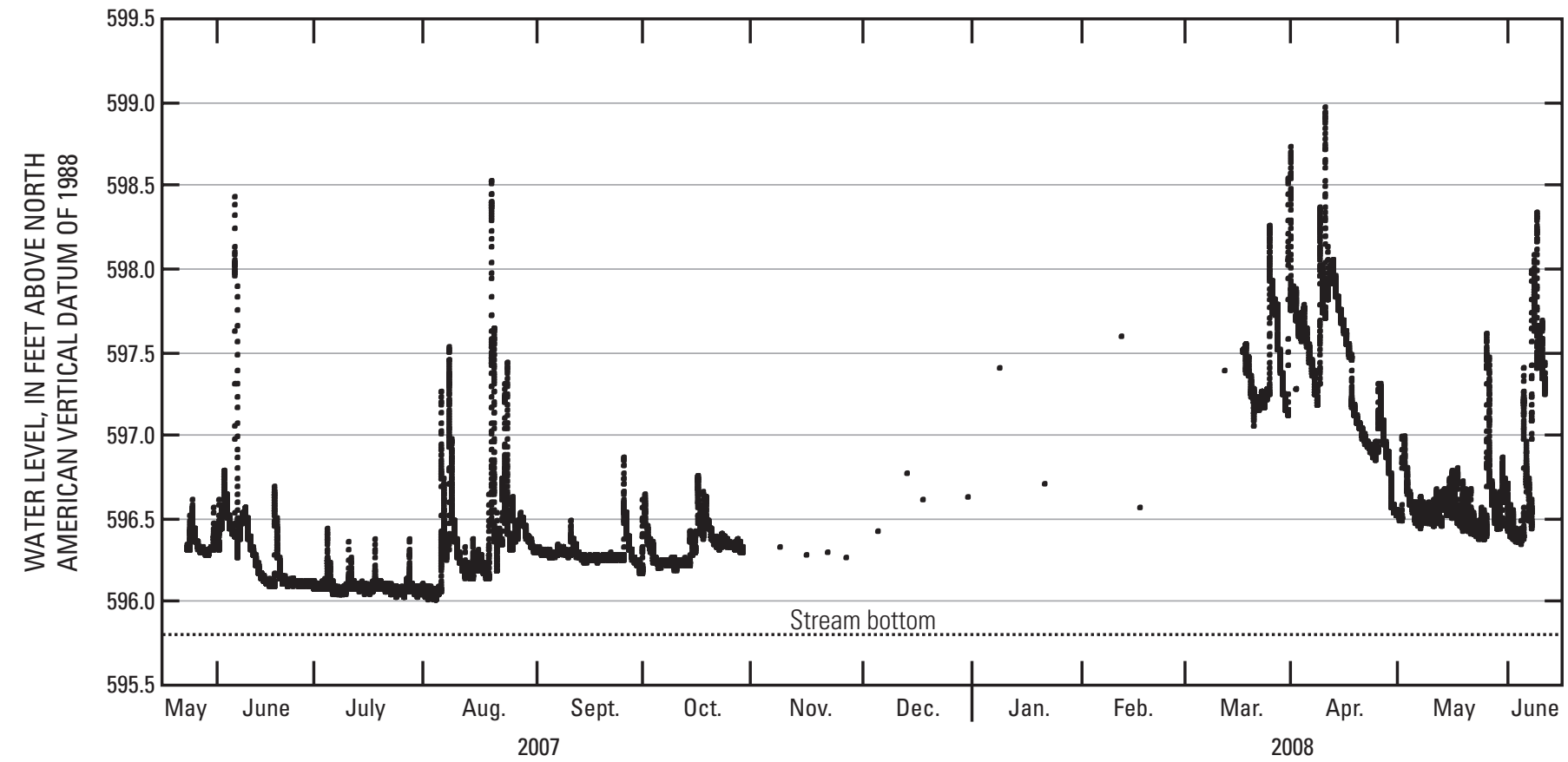

DATE

Figure 8. Water levels in Dead Dog Creek at gage DD1, May 25, 2007-June 11, 2008, in the vicinity of the Spring Bluff Nature Preserve, Winthrop Harbor, Illinois.

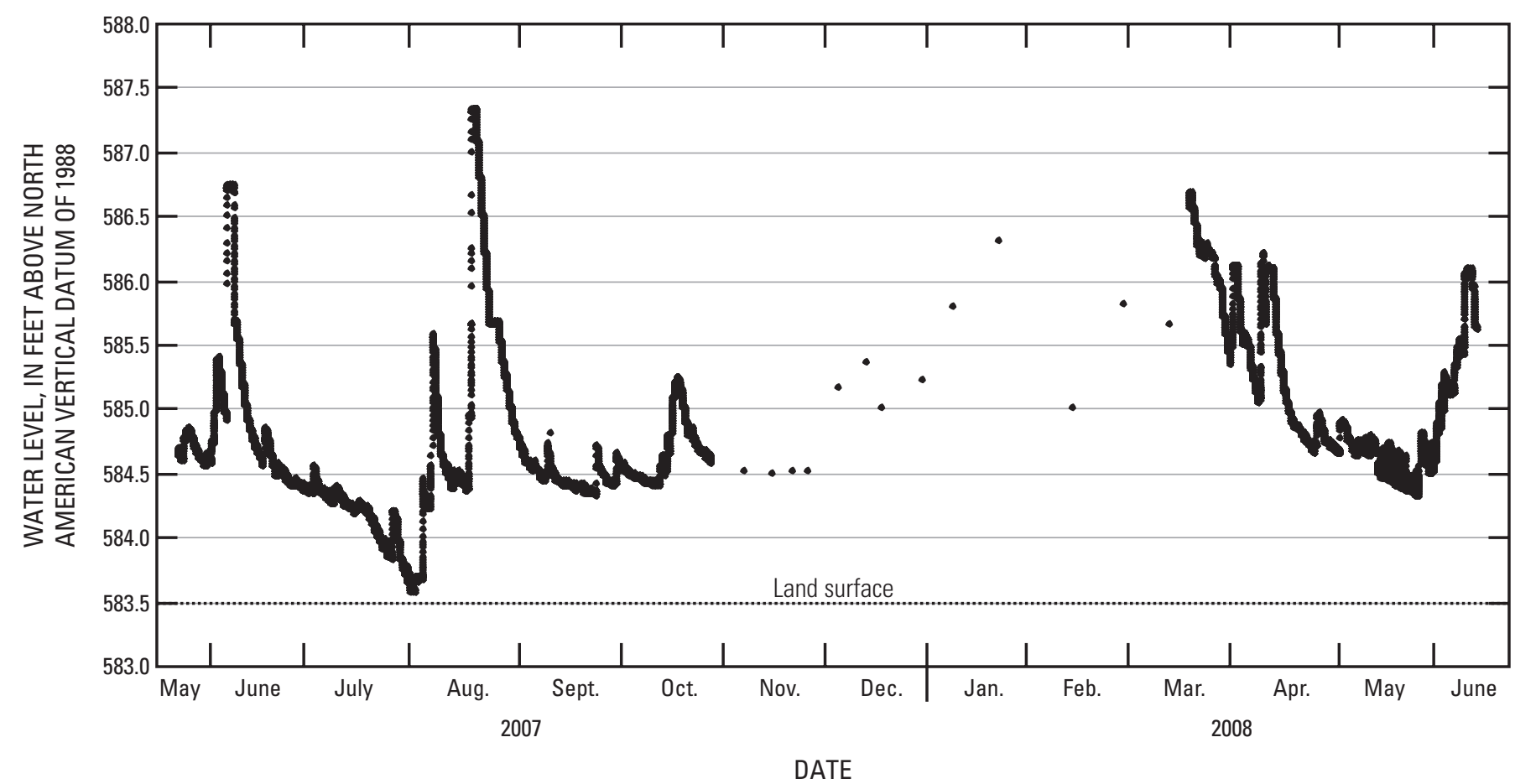

Figure 9. Water levels at gage W1, May 24, 2007-June 11, 2008, in the vicinity of the Spring Bluff Nature Preserve, Winthrop Harbor, Illinois. 
Water levels in the wetland complex were relatively high during most of August 2007 in response to a series of unusually large rainstorms (table 4; fig. 10) and were stable to slightly declining during September through mid-October 2007. Water levels began a general rise from mid-October 2007 through mid-April 2008 in response to decreased evapotranspiration and increased runoff from precipitation and snowmelt episodes. Water levels in the wetland complex then declined from mid-April 2008 through early June 2008 as, once again, runoff from precipitation decreased and evapotranspiration increased. Seasonal variations in meteorologic conditions tended to produce moderate to large changes in water levels $(0.5$ to about $2 \mathrm{ft}$ ) that lasted from a couple weeks to several months.

Superimposed on the seasonal trends in water levels are a number of shorter-term fluctuations in water levels associated with individual rain events during the spring, summer, and fall, as well as snowmelt events during the winter and spring. Examples of water-level responses to precipitation events at gages DD1 and W1 (figs. 8 and 9) can be seen on June 8, August 7, and August 19 and 20, 2007, and April 10 and June 8, 2008. The seasonal decline in water levels observed during June and July 2007 likely would have continued through October if not for the unusually large precipitation events in August, which resulted in a marked, prolonged increase in water levels in the study area. Water-level responses affected by precipitation and snowmelt events were present on January 9, and March 26, 2008. Precipitation events produced changes in water levels that tended to be proportionate to the amount of precipitation but could be as much as $3 \mathrm{ft}$ and could last for periods of a few days to a few weeks.

Finally, water levels at gage DD1 on Dead Dog Creek and some of the gages in the wetlands varied during the course of the day as the result of diurnal variations in evapotranspiration during the growing period. Evapotranspiration includes both direct evaporation from water surfaces and evaporation from leaves of transpiring plants. These processes are directly affected by temperature, wind, and solar radiation, which typically are higher during the day and lower at night (Mitsch and Gosselink, 2007). The effect of these processes on water levels tends to be cumulative over the course of the day. As a result, daily water levels varied by as much as $0.10 \mathrm{ft}$. Water levels typically were highest during the early morning hours before sunrise, decreased during the day, and reached minimum values near sundown, at which time water levels began to increase (fig. 11). Evapotranspiration effects were observed during about June 16-September 25, 2007. Evapotranspiration effects were not observed during 2008 prior to the termination of intensive water-level monitoring on June 11, 2008.

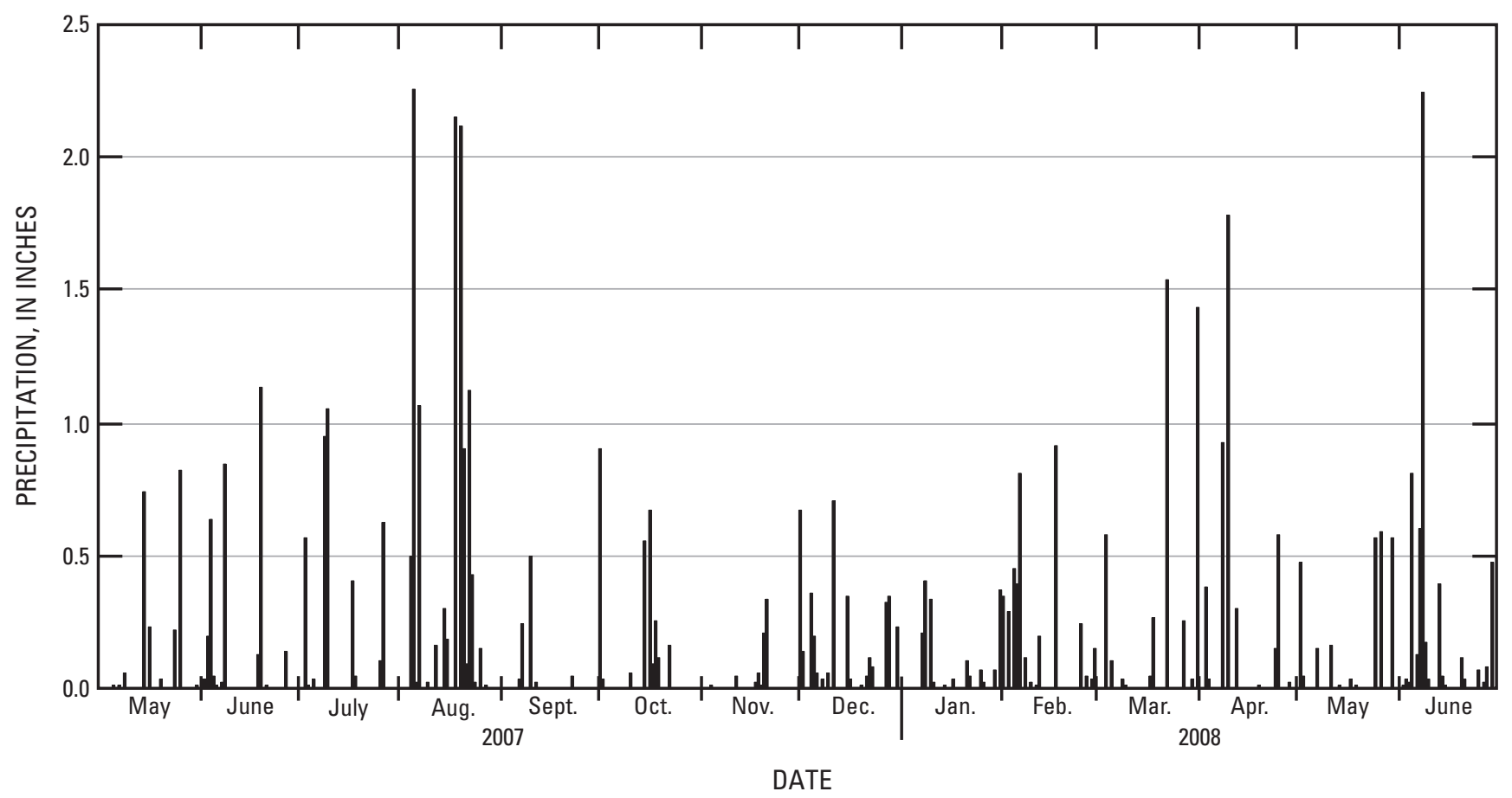

Figure 10. Precipitation measured at the National Oceanic and Atmospheric Administration Station, Kenosha, Wisconsin, May 1, 2007-June 30, 2008. 


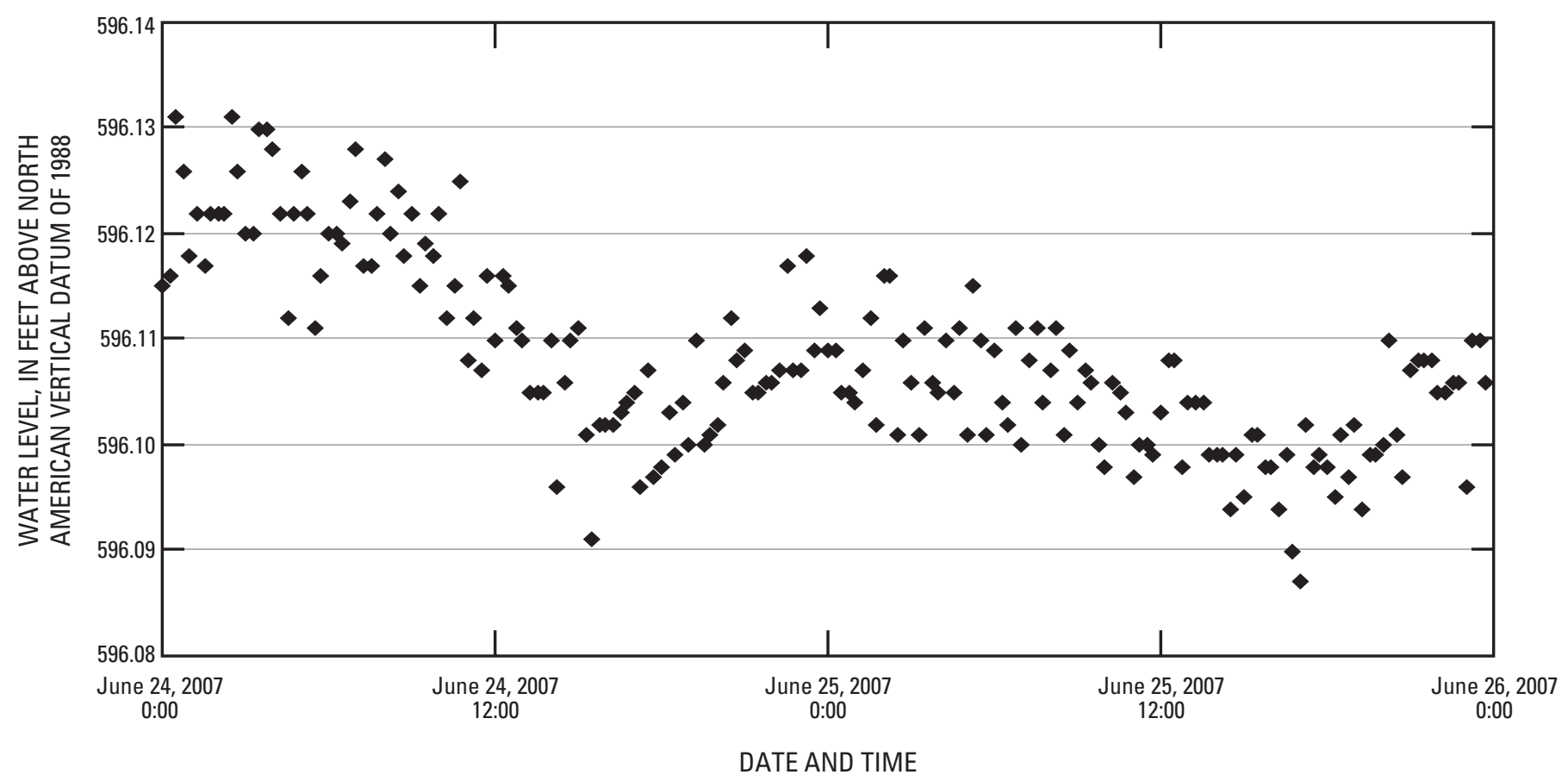

Figure 11. Water levels at gage DD1 in the vicinity of the Spring Bluff Nature Preserve, Winthrop Harbor, Illinois, June 24 and 25, 2007.

Evapotranspiration rates were estimated on June 24, July 12, July 27, September 5, and September 24, 2007, at gage DD1 on Dead Dog Creek and at wetland gages DD2, DR2, W1, W2, W3 and W4 by use of the water-level-fluctuation method (Mitsch and Gosselink, 2007; table 6). These dates were chosen because they cover the entire period when evapotranspiration effects were observed and correspond to dates when hydrologic conditions were stable and the effects of phenomena other than evapotranspiration on water levels were minimal or absent. This method relies on analysis of the change in water level during the nighttime hours and use of a specific yield value to determine the volume of water removed by evapotranspiration. Because these are surface-water bodies, the specific yield was assumed to be 1.0. Evapotranspiration effects were observed during at least four of the five dates for which estimates were made at gages DD1, W1, and W4. Evapotranspiration effects on water levels were not observed at gage DD2 during any of the dates for which estimates were made and were not observed at gages DR2, W2, and W3 during at least three of the dates. These gages all monitored areas of deep water. Evapotranspiration effects at these gages may have been absent because the volume of water evaporated and taken up by the plants was minimal compared to the large volume of water at these gages.
Evapotranspiration rates at gage DD1 ranged from 0.002 to $0.13 \mathrm{ft} / \mathrm{d}$ (table 6). Evapotranspiration rates at the gages in the wetlands (when and where present) ranged from 0.014 to $0.113 \mathrm{ft} / \mathrm{d}$. Evapotranspiration rates showed no clear variations with date or location.

In addition to evapotranspiration-induced effects and precipitation, water levels at gage DR3 also were affected by sandbars that frequently block the outlet of the Dead River (fig. 12) (Visocky, 1976). Sandbars are formed by the movement of sediment along the shore of Lake Michigan. When the force of the river flow is insufficient to erode more sediment than is being deposited by the longshore current, sediment builds up and a sandbar forms across the mouth of the river. The sandbar eventually dams the river, which increases the river stage. Eventually the river stage increases to a point where the sandbar is breached and the river discharges to Lake Michigan. This discharge erodes the sandbar, resulting in a decrease in river stage and discharge rate, which allows the sandbar to rebuild and the process to repeat. 
Table 6. Estimated evapotranspiration rates at selected gages in the vicinity of the Spring Bluff Nature Preserve, Chiwaukee Prairie State Natural Area, and Illinois Beach State Park, near Winthrop Harbor and Waukegan, Illinois. Locations of gages and wells are shown in figures $2-4$.

[np, not present]

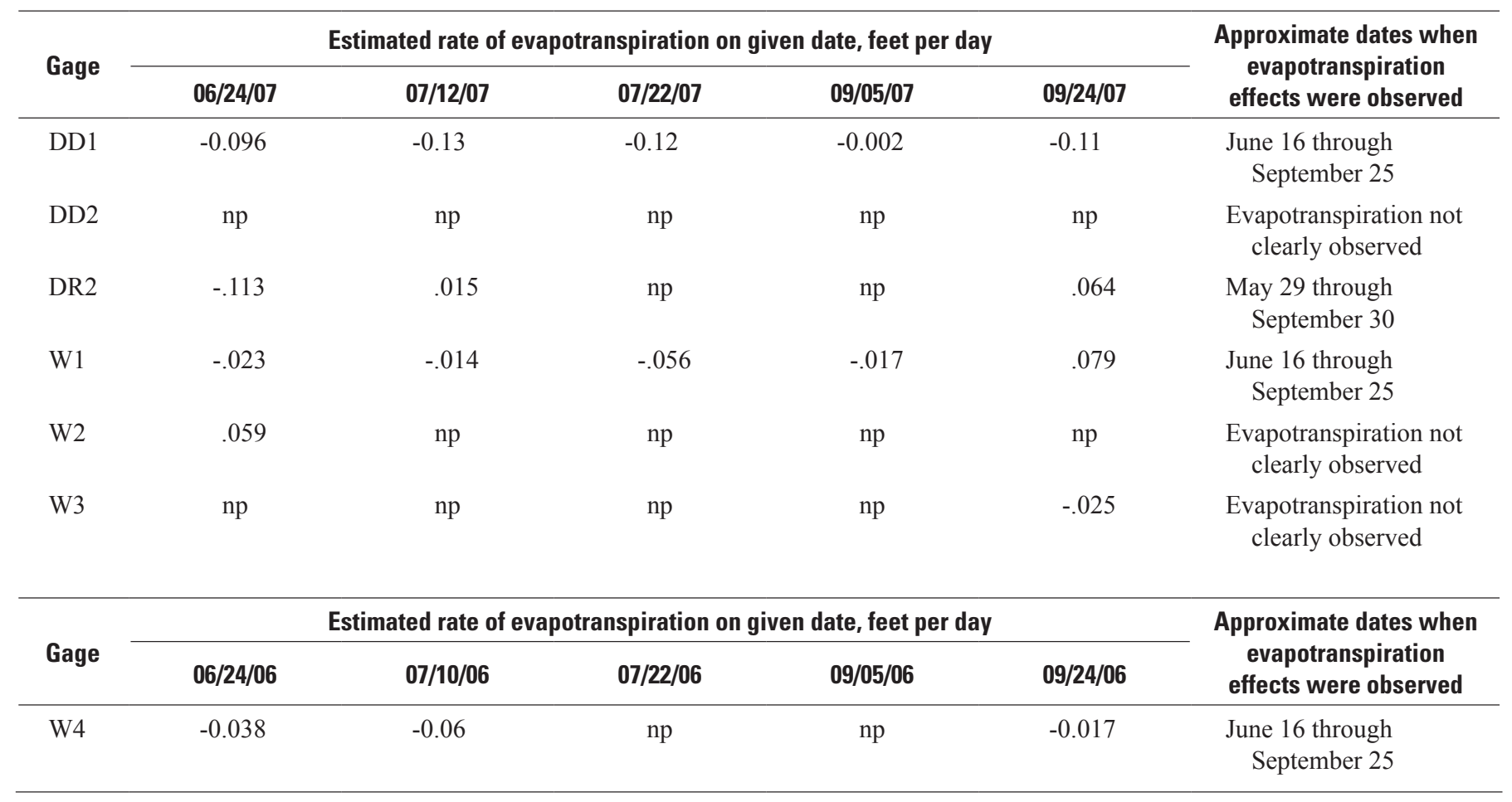

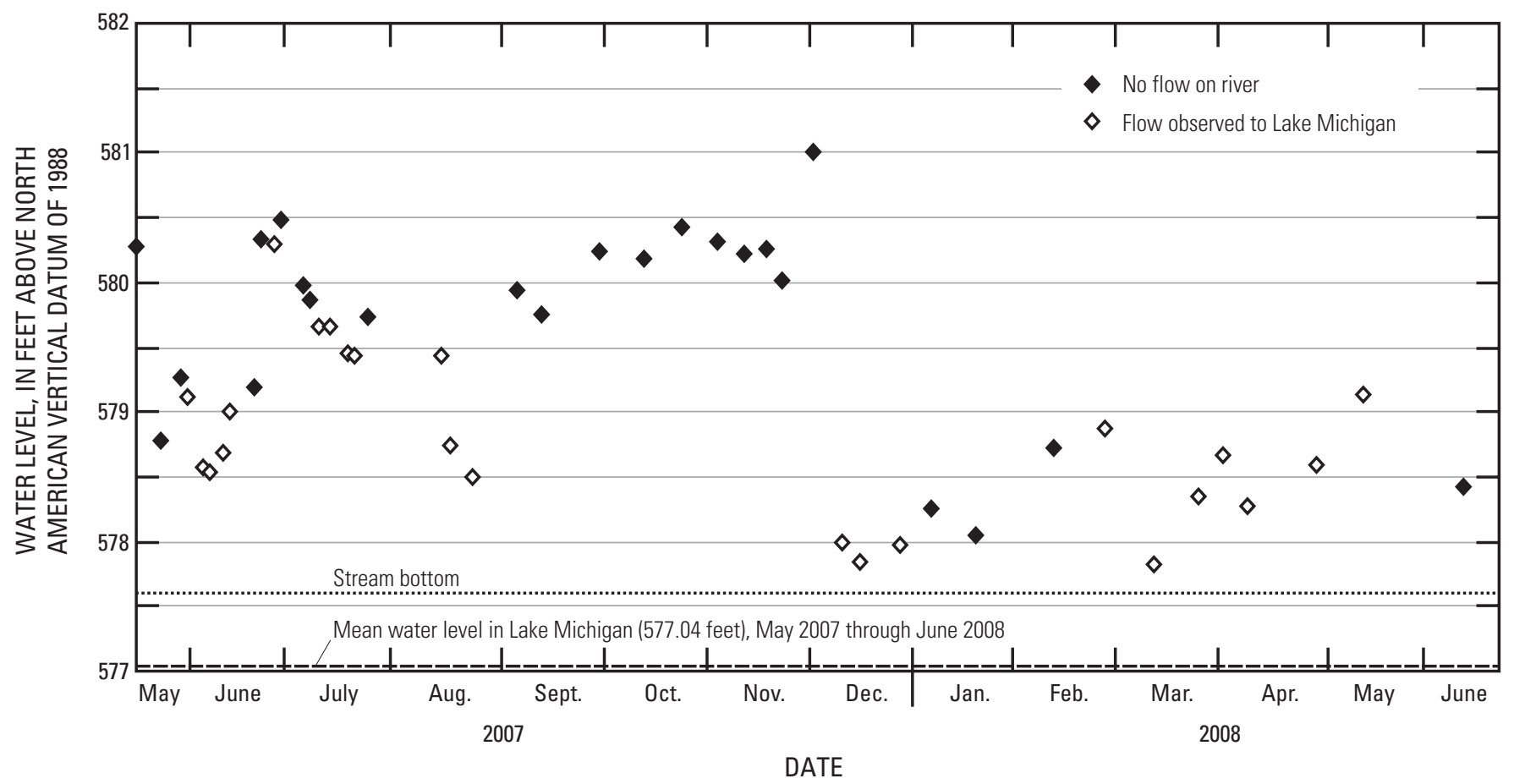

Figure 12. Water levels in the Dead River at gage DR3 in the Southern Unit of the Illinois Beach State Park near Waukegan, Illinois, May 24, 2007-June 11, 2008. 


\section{Direction and Timing of Surface-Water Flow}

Determination of surface-water flow directions within the various parts of the study area was based on water-level data from April 29, 2008, because there was water at all of the gages on this date. Use of this data set allowed the most comprehensive understanding of flow directions, including the assessment of the exchange of water between the creeks and the wetlands.

Surface-water flow into the SUIBSP in the southern part of the study area starts as channelized streamflow in Bull Creek (fig. 13). At the base of the bluff, water flows through culverts beneath the railroad tracks into the ponds and wetlands in the western part of the SUIBSP. Water then flows via the Dead River from the ponds through the rest of the SUIBSP past gage DR3 at the mouth of the river. Observations during water-level measurement events indicate that Bull Creek and the Dead River stayed within their banks for the majority of the investigation (table 7; appendix 1). However, water was observed flowing from the river channels and the ponds into the wetlands in the western part of the SUIBSP during periods of high water in spring 2007 and 2008.

Surface-water flow into the SBNP starts as channelized streamflow in Dead Dog Creek and smaller drainages coming off the bluff, including drainages in the southern part of the CPSNA (fig. 14). At the base of the bluff, surface topography flattens and water flows through culverts beneath the railroad tracks into the wetlands, swales, ditches, and channels east of the railroad tracks, such as those near gages W1, W3, and DD2.

Swales in the northwestern part of the SBNP and southwestern part of the CPSNA allow for the movement of surface water between the western parts of the SBNP and CPSNA. Topographic lows associated with swales and ditches also serve as conduits for flow from the central part of the SBNP north toward gage W1. This flow is indicated by the waterlevel elevations in the central part of the SBNP near gages W3 and DD2 that typically were about $2-5 \mathrm{ft}$ higher than the water-level elevation at gage $\mathrm{W} 1$ in the north-central part of the wetland (table 7; appendix 1). This northward flow is partly through a swale within the topographic high in the central part of the SBNP (fig. 6). Historical flow through an east-west-oriented ditch in the central part of the SBNP east of gage W3 (fig. 14) has been reduced by infilling. Limited flow from the central part of the SBNP to the south toward the NUIBSP also occurs. A berm associated with an access road near the state line north of gages W1 and W2 separates the wetlands along much of the central and eastern parts of the SBNP and CPSNA (figs. 3 and 6) except where a break in the berm allows for southward drainage from the CPSNA.
Surface-water flow south of the berm and east of gage W1 is through a series of man-made ditches and ponds into a channel that drains to Lake Michigan.

Water-level elevations in the north-central part of the SBNP at gage W1 typically were about $0.5-1.75 \mathrm{ft}$ lower than the water-level elevation at gage W2 in the northeastern part of the wetland (table 7; appendix 1). Because these water-level elevations indicate the potential for east-to-west flow in this area, which was not observed and which is counter to the prevailing flow direction, they indicate that surface water in the eastern part of the SBNP was at least partly isolated from surface water in the swales and ditches in the north-central parts of the SBNP by the topographically elevated features (ridge, access road, buildings) between gages W1 and W2 (compare figs. 3 and 6). The water-level elevation at gage $\mathrm{W} 1$ was higher than at gage W2 during a few measurements, primarily during periods of low water at gage W2 during November and December 2007.

Table 7. Summary of water levels at gages in the vicinity of the Spring Bluff Nature Preserve, Chiwaukee Prairie State Natural Area, and Illinois Beach State Park, near Winthrop Harbor and Waukegan, Illinois, May 24, 2007-June 11, 2008. Locations of gages are shown in figures 2-4.

[Bold denotes manual measurements only; NAVD 88, North American Vertical Datum of 1988; <, less than; >, greater than; *, partial period of record]

\begin{tabular}{lccc}
\hline Staff & $\begin{array}{c}\text { Minimum measured } \\
\text { water-level elevation } \\
\text { (feet above NAVD 88) }\end{array}$ & $\begin{array}{c}\text { Maximum measured } \\
\text { water-level elevation } \\
\text { (feet above NAVD 88) }\end{array}$ & $\begin{array}{c}\text { Range } \\
\text { (feet) }\end{array}$ \\
\hline DD1 & 596.00 & 598.96 & 2.96 \\
DD2 & 587.17 & 590.55 & 3.38 \\
DD3 & $<581.4$ & 582.94 & $>1.54$ \\
DD4 & 592.87 & 593.37 & .50 \\
SG1 & 586.29 & 588.52 & 2.23 \\
W1 & 583.57 & 587.33 & 3.76 \\
W2 $*$ & 583.51 & $>587.05$ & $>3.54$ \\
W3 & 586.90 & 589.62 & 2.72 \\
W4 & 584.64 & 586.88 & 2.24 \\
DR1 $*$ & 592.13 & 594.49 & 2.36 \\
DR2 & 584.30 & 585.38 & 1.08 \\
DR3 & 577.82 & 581.00 & 3.18 \\
\hline
\end{tabular}




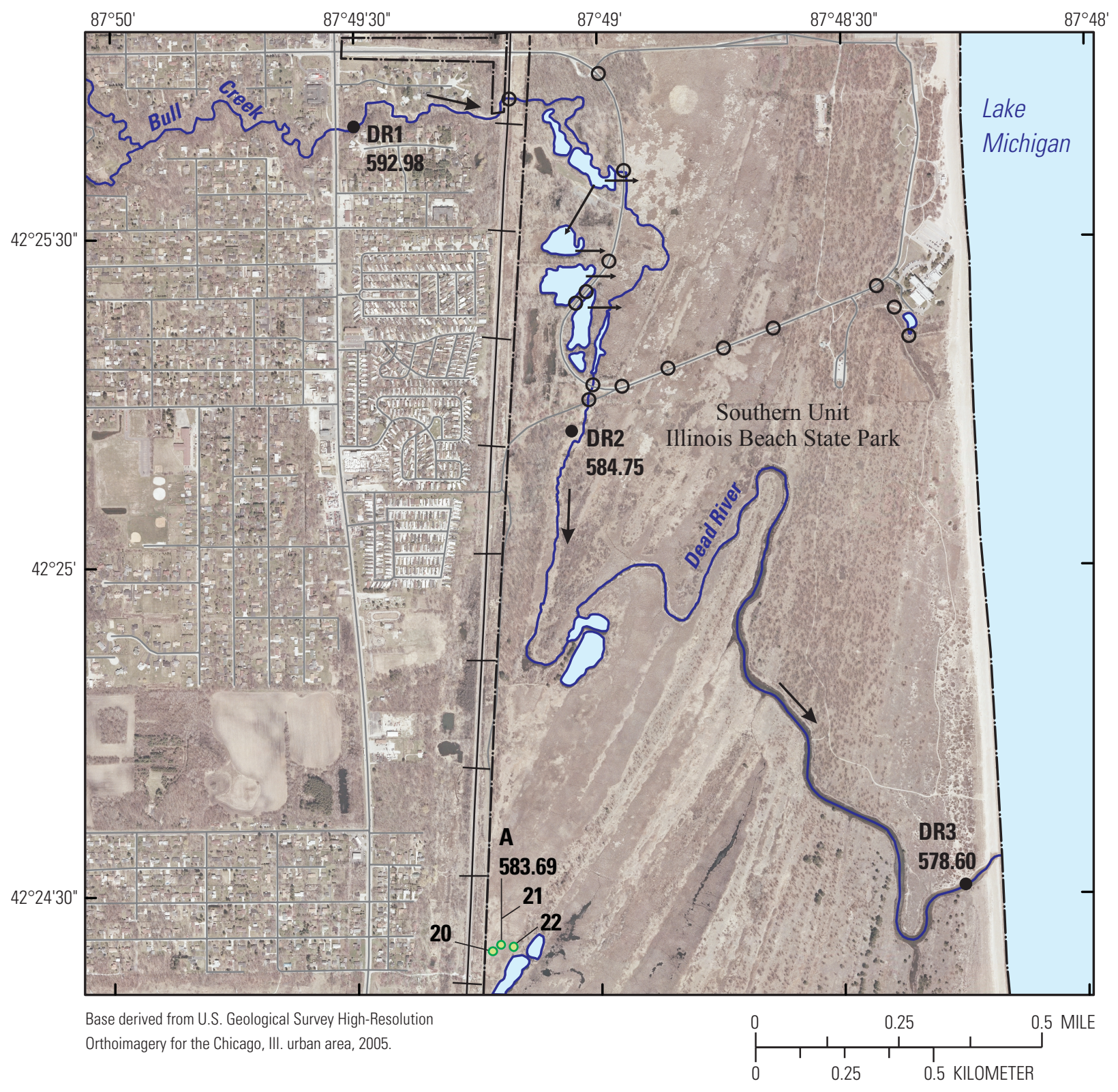

\section{EXPLANATION}

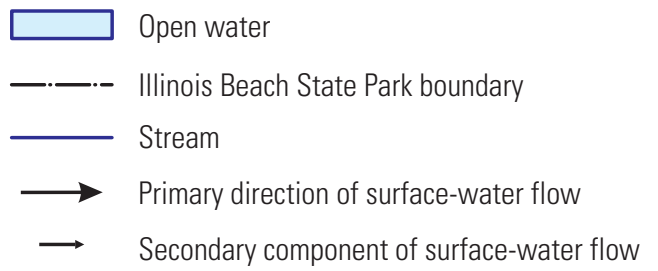

\begin{tabular}{|c|c|}
\hline $\begin{array}{l}\text { DR1 } \\
592.98\end{array}$ & $\begin{array}{l}\text { Surface-water measuring point, identifier, anc } \\
\text { water-level elevation, in feet above North } \\
\text { American Vertical Datum of } 1988 \text {. }\end{array}$ \\
\hline 20 & $\begin{array}{l}\text { Illinois State Geological Survey gage (A) and } \\
\text { well (20-22) }\end{array}$ \\
\hline 0 & Culvert \\
\hline
\end{tabular}

Figure 13. Surface-water levels and flow directions in the vicinity of the Southern Unit of the Illinois Beach State Park near Waukegan, Illinois, April 29, 2008. 


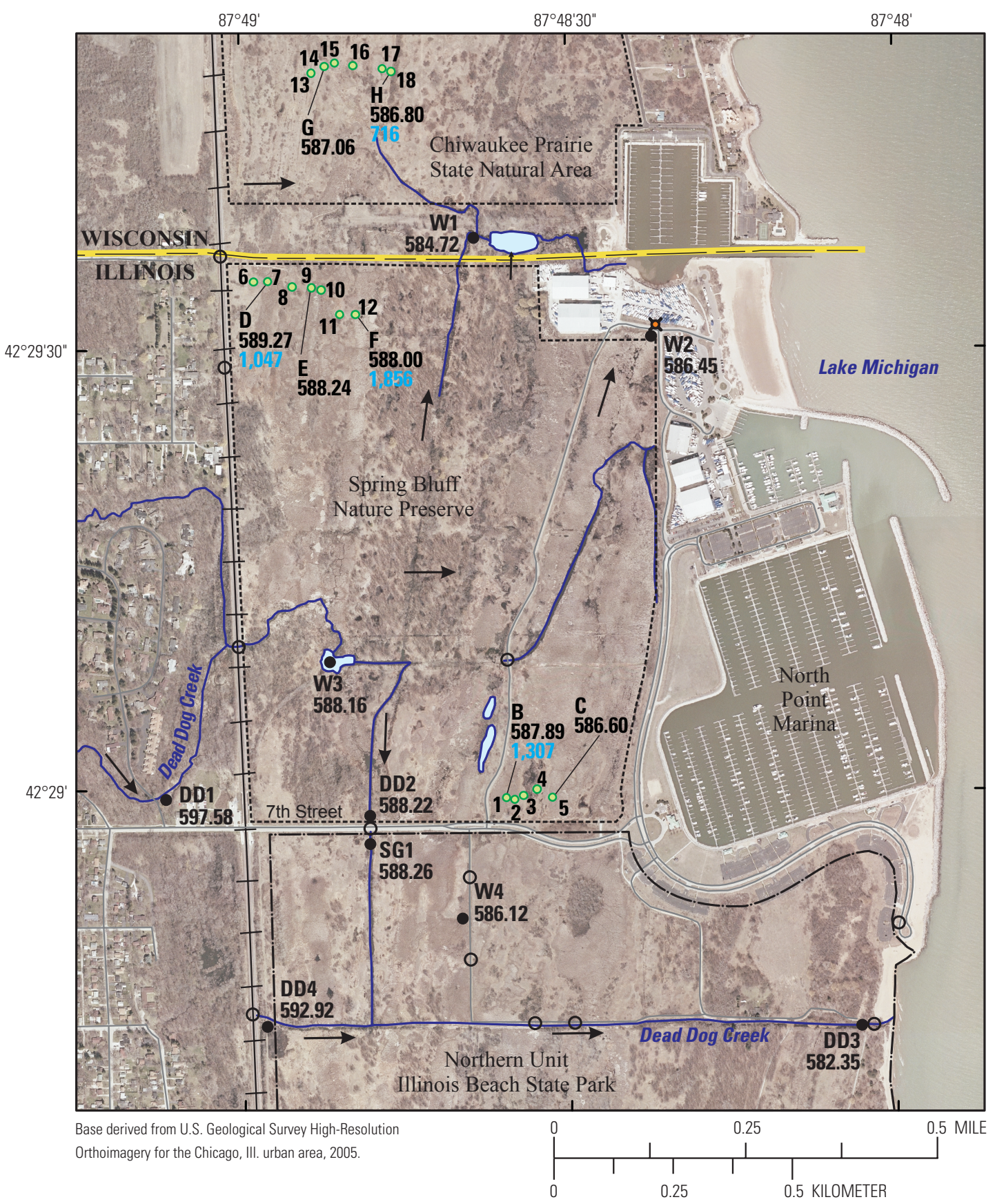

EXPLANATION

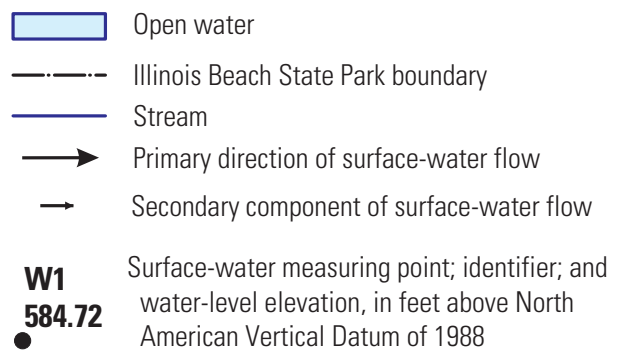 B well (1-18); identifier; water-level elevation, - 578.89 in feet above North American Vertical Datum 1,307 of 1988; and average specific conductance, in microsiemens per centimeter (in blue)
O Culvert
x Storm drain

Figure 14. Surface-water levels, specific conductance, and flow directions in the vicinity of the Spring Bluff Nature Preserve, Chiwaukee Prairie State Natural Area, and Northern Unit of the Illinois Beach State Park near Winthrop Harbor, Illinois, April 29, 2008. 
Water-level elevations in the central part of the SBNP near gages $\mathrm{W} 3$ and DD2 were 1-3 ft higher than the waterlevel elevation at gage $\mathrm{W} 2$ in the eastern part of the wetland (table 7; appendix 1), indicating that surface water had the potential to flow from the central to the eastern parts of the SBNP throughout the period of investigation. The access road near the central part of the SBNP is partly on a ridge that is somewhat topographically elevated relative to the surrounding wetlands. The ridge and road appear to restrict flow between the central and eastern parts of the SBNP. During periods of higher water levels, parts of the access road were flooded, and west-to-east flow likely was substantial. During periods of lower water levels, flow between the central and eastern parts of the SBNP is largely blocked by the ridge and access road, and flow between the central and eastern parts of the SBNP likely is small (fig. 14). The large difference in water-level elevations between gages DD2/W3 and W2 likely is partly owing to the flow restriction created by the road/ridge (and previously mentioned infilled ditch across these features), which results in the buildup of water in the central part of the SBNP during low-water periods.

The movement of water in the eastern part of the SBNP is partly controlled by the road on the eastern edge of the SBNP as well as the storm drain near gage W2 (fig. 14), which are alterations from the natural drainage. The elevation of the drain near gage W2 is about $586.1 \mathrm{ft}$. When water levels in the eastern part of the SBNP exceed this elevation (as happened during much of late May and early June 2007, much of August and early September 2007, and most of the period January-July 2008), water flows into the drain and out to Lake Michigan (table 7; appendix 1). When water levels are below this elevation (water depth at gage W2 less than about 2.8 $\mathrm{ft}$ ), surface water does not drain from the wetland but is lost to evapotranspiration and infiltration to groundwater. Water levels at gage W2 were less than $586.1 \mathrm{ft}$ during most or all of June, July, September, October, November, and December 2007.

Water-level elevations on the north side of the culvert beneath 7 th Street were at least $0.50 \mathrm{ft}$ higher at gage DD2 in the SBNP than on the south side at gage SG1 (fig. 14) in the NUIBSP for most of the investigation (table 7; appendix 1), indicating that this culvert, which partly was obstructed by sediment and debris, typically restricts surface-water flow from the SBNP to the NUIBSP. The exception to this period of restricted flow appears to have occurred during late April-June 2008, when water-level elevations at gages DD2 and SG1 differed by less than $0.10 \mathrm{ft}$ (appendix 1) and more substantial flow through the culvert was likely. Aside from the culvert, 7th Street itself eliminates the natural flow of surface water between the SBNP and the NUIBSP.

Surface-water flow into the western part of the NUIBSP south of 7th Street begins as overland runoff and storm drainage coming off the bluff west of the railroad tracks (fig. 14). Water then flows through culverts beneath the railroad tracks (such as the 4 -ft by 7 -ft culvert monitored by gage DD4) into the wetlands and stream channels of the NUIBSP east of the railroad tracks, where is meets southward drainage from the culvert beneath 7 th Street.

Water in the stream channels and wetlands in the western and central parts of the NUIBSP flows to the eastern part of the NUIBSP and out to Lake Michigan through a culvert (diameter about $2.5 \mathrm{ft}$ ) at gage DD3. The elevation of the base of the culvert at gage DD3 is about $581.4 \mathrm{ft}$. When water levels at the culvert exceeded this elevation (much of late May and early June 2007, much of August 2007, most of the period from late-December 2007 to the end of measurements in June 2008), water from the NUIBSP had the potential to flow through the culvert into Lake Michigan (appendix 1). When water-level elevations were below this elevation (most or all of June, July, September, October, November, and December 2007 and February 2008), water in the NUIBSP area did not drain from this part of the wetland but was lost to evapotranspiration or infiltration to groundwater.

Additional insight into the hydrology of the northern part of the study area was obtained by examining the timing of water-level changes in response to a precipitation event that occurred on June 8, 2007 (fig. 10). The storm was a short, isolated event (the nearest dates when more than trace amounts of precipitation was recorded were June 4 and 18) of moderate size (0.84 in.), and it produced a distinct rise in water levels at the gages in the SBNP and CPSNA.

On Dead Dog Creek west of the SBNP, the water-level elevation at gage DD1 peaked at about 0600 hours Central Daylight Time (CDT) on June 8 and returned to pre-precipitation event water levels - a change of about $1.6 \mathrm{ft}$ - several hours later (fig. 15). In the western and central parts of the SBNP the water-level rises at gages W3 and DD2 were nearly identical, indicating free flow of surface water within the central part of the SBNP. Water levels peaked on June 8 at about 1000 hours CDT and remained near this level for about 1 day before water levels slowly began to decline. By June 17, water levels in these gages were approximately $0.3 \mathrm{ft}$ above their pre-June 8 levels. The rise in water levels at gages W3 and DD2 was about $1.0 \mathrm{ft}$. Water levels near the northern part of the SBNP at gage W1 peaked on June 8 at about 1400 hours CDT and slowly decreased to pre-June 8 water levels (difference of about $2.0 \mathrm{ft}$ ) on June 15. The response at gage W4 (not shown in the figure) in the central part of the NUIBSP to the precipitation was similar to the response in the central part of the SBNP at gage DD2. The water level at gage W4 peaked on June 9 at about 0400 hours CDT and remained at that level for about 4 days, then slowly decreased to pre-June 8 water levels on June 15. The change in water levels at gage W4 was about $1.15 \mathrm{ft}$. Finally, water levels in the western part of the SBNP at gage W2 peaked on June 9 at about 1200 hours CDT and remained near that level for about 4 days before slowly declining. The water level in this gage was approximately $0.8 \mathrm{ft}$ above its pre-June 8 level on June 17. The water-level response at this gage was about $1.5 \mathrm{ft}$. 


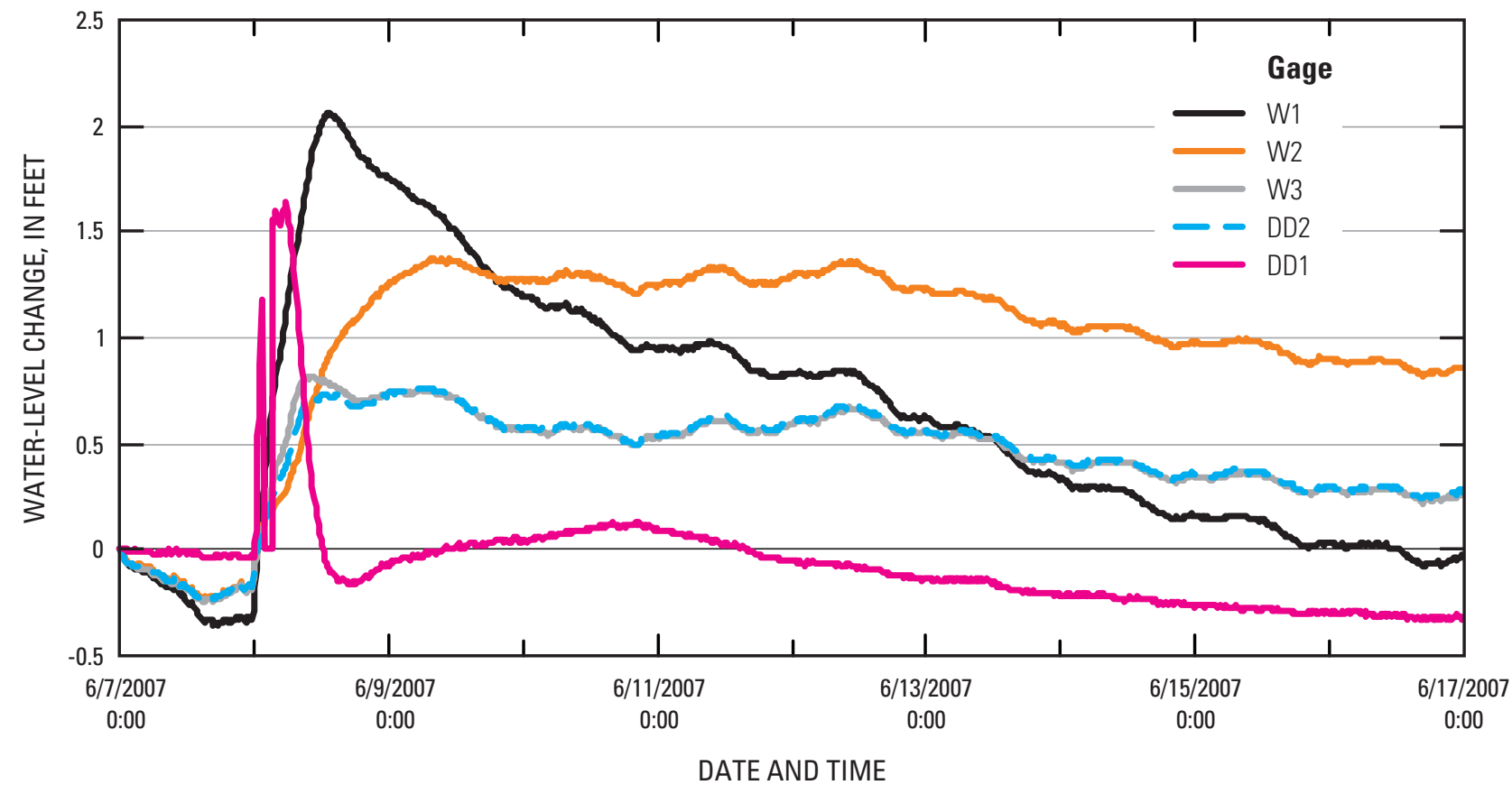

Figure 15. Hydrograph showing water-level responses to June 8, 2008, rainfall, Spring Bluff Nature Preserve, Winthrop Harbor, Illinois.

These data indicate that the water-level response to the June 8 rainfall was largest and quickest on the bluff at gage DD1 and in the swale at gage W1. These are the areas of the most channelized surface-water movement, with flow at gage DD1 draining into the wetlands in the center of the SBNP and flow in the swale at gage $\mathrm{W} 1$ draining to the ponds north of the SBNP and then into Lake Michigan. The water-level response (change in water level and duration of impact) to the June 8 precipitation was intermediate at gages $\mathrm{W} 3$ and DD2. These are relatively wide, flat areas with low to moderate water movement, where flow is to the north through the swale in the center of the SBNP and east toward gage W2 through the culvert beneath, and perhaps over, the access road in the east-central part of the SBNP. The water-level response to the June 8 precipitation at gage W2 was characterized by a large, somewhat delayed, rise in water level of relatively long duration as precipitation and surface-water inflow from the western part of the SBNP accumulated in the depressions in the eastern part of the SBNP. This area has the most restricted surface flow-bounded by the roads and dunes to the north, south, east, and west (fig. 6). Once collected in this area, water slowly drains to Lake Michigan via the storm drain in the northeastern corner of the SBNP (fig. 15) as well as evapotranspiration and discharge to groundwater.

\section{Hydroperiod}

Water-level measurements at gages W1, W2, W3, and DD2 (table 8) in the SBNP during May 24, 2007-May 24, 2008 , indicate that water depths were greatest for the longest periods of time at gage $\mathrm{W} 3$ (depth typically exceeded $2.5 \mathrm{ft}$ ), at gage DD2 (depth typically exceeded $1 \mathrm{ft}$ ), and in the wetlands near the storm drain control structure at gage W2 (depth typically exceeded $2 \mathrm{ft}$ ). These gages had standing water (or ice) for the entire period of investigation. Water depth and duration of inundation were lower at gage $\mathrm{W} 1$, where water depth typically exceeded $1 \mathrm{ft}$, but the gage was nearly dry for a 1 to 2 week period.

Gage W3 is in a man-made pond (fig. 14) where water levels are atypically deep for this area. The depth of water is greater and the period of inundation is longer at this gage relative to natural conditions because of the depth of the pond as well as the possible buildup of water in the western part of the SBNP owing to flow restrictions associated with 7th Street and the access road in the central part of SBNP.

Gage W1 is in a swale near relatively undisturbed parts of the wetland complex to the west. Ditches to the east of the gage likely would facilitate water drainage (fig. 14).

Gage DD2 is in a man-made drainage ditch near the upstream side of the partly obstructed culvert beneath 7th Street (fig. 14). The depth of water is greater and the period of inundation likely is longer at this gage relative to natural conditions because of the flow restriction created by 7th Street and the blocked culvert.

Gage W2 is in a part of the wetland complex that is somewhat isolated from the overall drainage by the surrounding roads (figs. 6 and 14), which create topographically elevated areas that restrict surface-water drainage. Gage W2 also is near a drainage control structure. 
Table 8. Hydroperiod, in days, at selected gages in the wetlands in the vicinity of the Spring Bluff Nature Preserve, Chiwaukee Prairie State Natural Area, and Illinois Beach State Park, near Winthrop Harbor and Waukegan, Illinois, May 24, 2007-May 24, 2008. Locations of staff gages are shown in figures $2-4$.

[NAVD 88, North American Vertical Datum of 1988; na, not applicable; *, less than 0.10 foot of water at gage during some periods]

\begin{tabular}{ccccccccc}
\hline $\begin{array}{c}\text { Elevation } \\
\text { (feet above } \\
\text { NAVD 88) }\end{array}$ & \multicolumn{7}{c}{ Number of days water level exceeded elevation (hydroperiod) at indicated gage } \\
\cline { 2 - 9 } & W1 & W2 & W3 & DD2 & SG1 & W4 & DD3 & DR2 \\
\hline 590.0 & 0 & 0 & 0 & 0 & 0 & 0 & 0 & 0 \\
589.5 & 0 & 0 & 0 & 2 & 0 & 0 & 0 & 0 \\
589.0 & 0 & 0 & 33 & 23 & 0 & 0 & 0 & 0 \\
588.5 & 0 & 0 & 145 & 172 & 4 & 0 & 0 & 0 \\
588.0 & 0 & 0 & 330 & 329 & 160 & 0 & 0 & 0 \\
587.5 & 0 & 0 & 341 & 343 & 249 & 0 & 0 & 0 \\
587.0 & 3 & 15 & 366 & 366 & 329 & 0 & 0 & 0 \\
586.5 & 15 & 47 & 366 & na & 340 & 73 & 0 & 0 \\
586.0 & 72 & 154 & 366 & na & 366 & 175 & 0 & 0 \\
585.5 & 111 & 214 & 366 & na & na & 327 & 0 & 0 \\
585.0 & 186 & 266 & na & na & na & 341 & 0 & 55 \\
584.5 & 276 & 303 & na & na & na & 366 & 0 & 325 \\
584.0 & 354 & 325 & na & na & na & na & 0 & 366 \\
583.5 & $* 366$ & 336 & na & na & na & na & 0 & 366 \\
583.0 & na & $* 366$ & na & na & na & na & 0 & na \\
582.5 & na & na & na & na & na & na & 54 & na \\
582.0 & na & na & na & na & na & na & 158 & na \\
581.5 & na & na & na & na & na & na & 166 & na
\end{tabular}

The combination of surrounding landscape and drainage control structures restricts the amount of surface drainage from the eastern part of the SBNP, as well as the stage at which drainage may occur. For these reasons, the depth of water is greater and the period of inundation likely is longer at gage W2 relative to natural conditions. Data indicate that surface water flowed from the wetlands to Lake Michigan for about 154 days at gage W2 during the period from May 24, 2007, to May 24, 2008, primarily during late May and early June 2007, much of August and early September 2007, and most of the period January-May 2008.

Hydroperiods at gages SG1, W4 and DD3 in the NUIBSP during May 24, 2007-May 24, 2008, show that water depths were greatest (depth typically exceeded $1.5 \mathrm{ft}$ ) and water was present for the longest period of time (the entire period of monitoring) at gage SG1, shortest at gage DD3 (area was dry for nearly half the data-collection period), and intermediate length at gage W4 (depth typically exceeded $1 \mathrm{ft}$, but area could be nearly dry for periods of weeks) (table 8).

Gage W4 is in a wetland swale next to an access road in a part of the wetland complex (the NUIBSP) that appears to be well drained by ditches (figs. 6 and 14) and that typically is isolated from substantial sources of inflowing surface water. The depth of water and period of inundation at this gage likely are lower than would be typical under natural conditions. Surface-water conditions in the swale appear to be typical of the wetlands in this part of the study area.

Gage DD3 is in a man-made drainage ditch at a culvert in the eastern part of the wetland complex near the point of discharge to Lake Michigan. The depth of water and period of inundation at this gage appear to be greater relative to natural conditions because of the effects of the ditch and the culvert, but they may be decreased somewhat by the overall lack of flow from the SBNP into the NUIBSP because of the flow obstruction at 7th Street and its culvert. Hydroperiod data indicate that the potential for surface-water discharge from these wetlands to Lake Michigan existed for about 166 days at gage DD3, for the period May 24, 2007-May 24, 2008. The channel from gage DD3 to the lake may have been blocked by the buildup of sand at the lakeshore during some of this time. This location is immediately south (downdrift) of a beachnourishment sand pile. 


\section{Surface-Water Discharge}

Discharge was measured (or visually estimated when flow was too low to be quantified or water levels were too low for a measurement) at gages DD1, DD2, DD3, DD4, SG1, W1, DR1, DR2, and DR3 during the periodic water-quality sampling events (table 9). As a consequence, these measurements were collected during random weather conditions and therefore are not representative of the total range of discharge (particularly the higher values) during the investigation.

Discharges typically were greatest at gages DD1 and DR1 because their position on the bluffs west of the coastal complex facilitates water movement, and they drain fairly large watersheds. Discharge in the bluff area at gage DD4 typically was absent or less than $0.01 \mathrm{ft}^{3} / \mathrm{s}$. Gage DD4 drains a small watershed that receives discharge primarily from stormwater. Discharge at gages DD1, DR1, and DD4 was greatest during April and May 2008, most likely because of the higher volume of runoff from precipitation events during this time, and least during July 2007 owing to seasonally low runoff (table 9). This pattern is typical of annual stream discharge cycles in northern Illinois (Hensel, 1992).

Discharge at the gages in the ditches and swales in the wetland areas (gages W1, DD2, DR2, SG1) typically was estimated to be at or near zero (table 9) because the topographic gradient in the wetland complex is low and the area for flow is large. Measurable discharge was present at gages $\mathrm{W} 1$ and DR2 during the spring months, when water levels and runoff were highest, but was not detected during most of the periods when water levels were lower. It is probable that measurable amounts of discharge passed gages W1 and DR2 after precipitation events, but these events were not monitored. Flow also was not observed through the culvert at 7 th Street at any time during the investigation, most likely because this culvert was partially blocked by sediment or debris. It is apparent that 7th Street restricts surface-water flow between SBNP and the NUIBSP and that these areas are partly isolated from each other (from a surface-water perspective) except during periods when water levels are above the restrictions in the culvert.

Discharge at gages DD3 and W2, located near the outlets to Lake Michigan, was affected by the water-level elevation in the wetlands. Discharge of surface water from the wetlands at the NUIBSP and eastern part of the SBNP into Lake Michigan occurred only during periods when water levels were above threshold altitudes at these gages, such as occurred after the precipitation events in August 2007, during the spring of 2007 , and the spring and early summer of 2008. Precipitation amounts were unusually high during parts of the summers of 2007 and 2008 (table 4). Surface-water discharge from these wetlands to Lake Michigan likely is minimal or absent during substantial parts of a typical year, including most of a typical summer.

The presence of discharge from the SUIBSP to Lake Michigan via the Dead River was affected by whether or not a sandbar was blocking the outlet to Lake Michigan (gage DR3, table 9). When a sandbar was present, there was no discharge at gage DR3. When the sandbar was eroded by waves or overtopped by high water levels in the Dead River, discharge could be substantial. The presence or absence of discharge at gage DR3 was sometimes noted during the water-level measurements (appendix 1). These observations, combined with the hydrograph for gage DR3 (fig. 12), indicate that discharge from the Dead River to Lake Michigan was sporadic but occurred during high-water periods at the end of May through much of June and mid-July 2007, probably occurred after the precipitation events during August 2007, and occurred during much of mid-December 2007 through May 2008. Discharge was not observed during the latter part of July 2007 and from October through mid-December 2007.

Table 9. Streamflow measurements at selected gages in the vicinity of the Spring Bluff Nature Preserve, Chiwaukee Prairie State Natural Area, and Illinois Beach State Park, near Winthrop Harbor and Waukegan, Illinois, May 24, 2007-May 13, 2008. Locations of gages are shown in figures $2-4$.

[--, measurement not made; <, less than; e, estimated, flow rate too low to be quantified; flow, flow observed but was not quantified]

\begin{tabular}{ccccccc}
\hline \multirow{2}{*}{ Staff gage } & \multicolumn{5}{c}{ Flow, in cubic feet per second } \\
\cline { 2 - 7 } & $\mathbf{0 5 / 2 4 / 0 7}$ & $\mathbf{0 5 / 2 5 / 0 7}$ & $\mathbf{0 6 / 2 7 / 0 7}$ & $\mathbf{0 7 / 3 0 / 0 7}$ & $\mathbf{0 4 / 0 2 / 0 8}$ & $\mathbf{0 5 / 1 3 / 0 8}$ \\
\hline DD1 & -- & 0.26 & 0.18 & 0.01 & 6.4 & 0.59 \\
DD2 & $<0.01 \mathrm{e}$ & -- & $<.01 \mathrm{e}$ & $<.01 \mathrm{e}$ & $<.01 \mathrm{e}$ & $<.01 \mathrm{e}$ \\
DD3 & $<.01 \mathrm{e}$ & -- & 0 e & dry & 2.89 & .003 \\
DD4 & $<.01 \mathrm{e}$ & -- & $<.01 \mathrm{e}$ & dry & .22 & $.1 \mathrm{e}$ \\
SG1 & $<.01 \mathrm{e}$ & -- & $<.01 \mathrm{e}$ & $<.01 \mathrm{e}$ & $<.01 \mathrm{e}$ & $<.01 \mathrm{e}$ \\
W1 & .19 & -- & 0 e & $0 \mathrm{e}$ & 4.62 & .17 \\
W2 & -- & -- & -- & -- & flow & flow \\
DR1 & -- & .71 & 1.08 & .05 & 14.7 & .94 \\
DR2 & -- & $0 \mathrm{e}$ & $0 \mathrm{e}$ & $0 \mathrm{e}$ & 10.8 & 0 e \\
DR3 & -- & .00 & 1.58 & $0 \mathrm{e}$ & 63.4 & 6.0 \\
\hline
\end{tabular}


Previous investigators have noted that sandbar formation occasionally prevented discharge to Lake Michigan via the ditch in the NUIBSP at gage DD3 (Visocky, 1976; Kubillus, 1994). However, discharge restriction owing to sandbars was not observed when measurements were made during the current investigation.

\section{Implications of Surface-Water Hydrology}

Characterization of presettlement surface-water hydrology is not possible given the lack of presettlement data in this area. However, agricultural and urban land use within a watershed typically increase overland runoff of precipitation in comparison to presettlement conditions (U.S. Department of Agriculture, 1996; Konrad, 2003; Konrad and Booth, 2005). It is probable, therefore, that the amount of surface-water inflow to the wetland complex has been greater in recent years than in the past and is likely contributing to the apparently higher water levels in parts of the wetland complex.

In the SUIBSP, the wetland complex receives surface water from direct precipitation and inflow from Bull Creek, a perennial stream draining a watershed of more than $5.5 \mathrm{mi}^{2}$. As a consequence, the SUIBSP receives a continuous input of surface water. The inflow is offset by evapotranspiration, discharge to groundwater, and intermittent outflow of the Dead River to Lake Michigan. The road through the SUIBSP likely reduces the exchange of water between Bull Creek and the Dead River with the surrounding wetlands, but the numerous open culverts in the area (fig. 4) partly counteract this restriction.

In the northern part of the study area, the SBNP and CPSNA receive surface water from direct precipitation and inflow from Dead Dog Creek, a perennial stream draining a watershed of about $1.5 \mathrm{mi}^{2}$. The SBNP and CPSNA also receive smaller amounts of water from smaller perennial and intermittent drainages north of Dead Dog Creek. As a consequence, this part of the wetland complex receives a continuous input of surface water. This inflow typically is offset by the removal of water via drainage to the surface-water outlet near the state line and to a lesser extent the culvert beneath 7th Street, flow into the storm drain near gage W2, discharge to groundwater, and evapotranspiration. The roads, obstructed culverts, berms, and ditches at the SBNP restrict the movement of water between the western, central, and eastern parts of the wetland complex in this area as well as between the SBNP and the NUIBSP (this restriction is minimized during periods of high water). This alteration of the presettlement flow conditions results in the accumulation of water in the SBNP, especially near the eastern part and points of inflow. Water collects in the eastern part of the SBNP because it is a topographically low area surrounded by topographically elevated areas associated with roadways and dunes, and it typically has only one small, intermittent outlet for surface-water discharge, which is at a higher elevation that the surrounding wetland bottom. These changes in the topography and hydrology likely have resulted in longer periods of higher water levels in the eastern part of the SBNP relative to presettlement conditions. The effect of these alterations on the hydroperiod in the central and western parts of the SBNP is less clear, but it appears that water levels may be elevated for an indeterminate-but longer - period of time, resulting from the higher amounts of inflow and disruptions to water movement caused by the roads and obstructed culverts in the central, northeastern, and southern parts of the SBNP.

In the northern part of the study area, the NUIBSP receives intermittent surface-water inflow from a small $\left(0.4 \mathrm{mi}^{2}\right)$ drainage during storms and snowmelt, intermittent inflow from the drainage ditch under the culvert at 7 th Street, and input directly from precipitation. As a consequence, this part of the wetland complex receives smaller amounts of surface water relative to the rest of the study area. Water is removed from this area via intermittent drainage to Lake Michigan near gage DD3, evapotranspiration, and discharge to groundwater. Roads, obstructed culverts, berms, and ditches at the NUIBSP appear to restrict surface-water flow into, and increase the drainage out of, the NUIBSP in comparison to presettlement conditions. As a result, water levels in the NUIBSP likely are lower, and are elevated for shorter periods of time, than would be typical of natural conditions.

\section{Groundwater Hydrology}

Previous investigators have determined that groundwater and the surface water in the creeks and wetlands of the study area interact in a spatially and temporally complex manner (Visocky, 1976; Kubillus, 1994). Detailed investigation of groundwater hydrology and surface-water groundwater interactions is beyond the scope of this investigation. However, water-level data from the wells in the study area were used to measure hydroperiods in various plant communities to help determine if hydraulic alterations could be related to changes in the plant communities. 


\section{Groundwater Levels Through Time}

Trends in groundwater levels are similar to those of surface water, indicating they were responding to the same hydraulic influences. Generally, groundwater levels were low in July 2007 as a result of decreased availability of infiltrating water and increased evapotranspiration in summer (Hensel, 1992), but levels increased greatly in August 2007 in response to record amounts of rainfall (fig. 16). Groundwater declined to more typical seasonal levels by October 2007 and continued to decline through late fall 2007. Water levels increased from late fall 2007 through late spring 2008 in response to recharge from rainfall, snowmelt, and surface water and decreased evapotranspiration. Water levels again declined in late spring 2008 through the end of summer, as evapotranspiration increased and the availability of surface water and precipitation for recharge decreased. Trends in groundwater levels showed similarities between wells in different types of plant communities even though ranges of levels relative to land surface differed considerably among the various communities, as discussed in the next section.

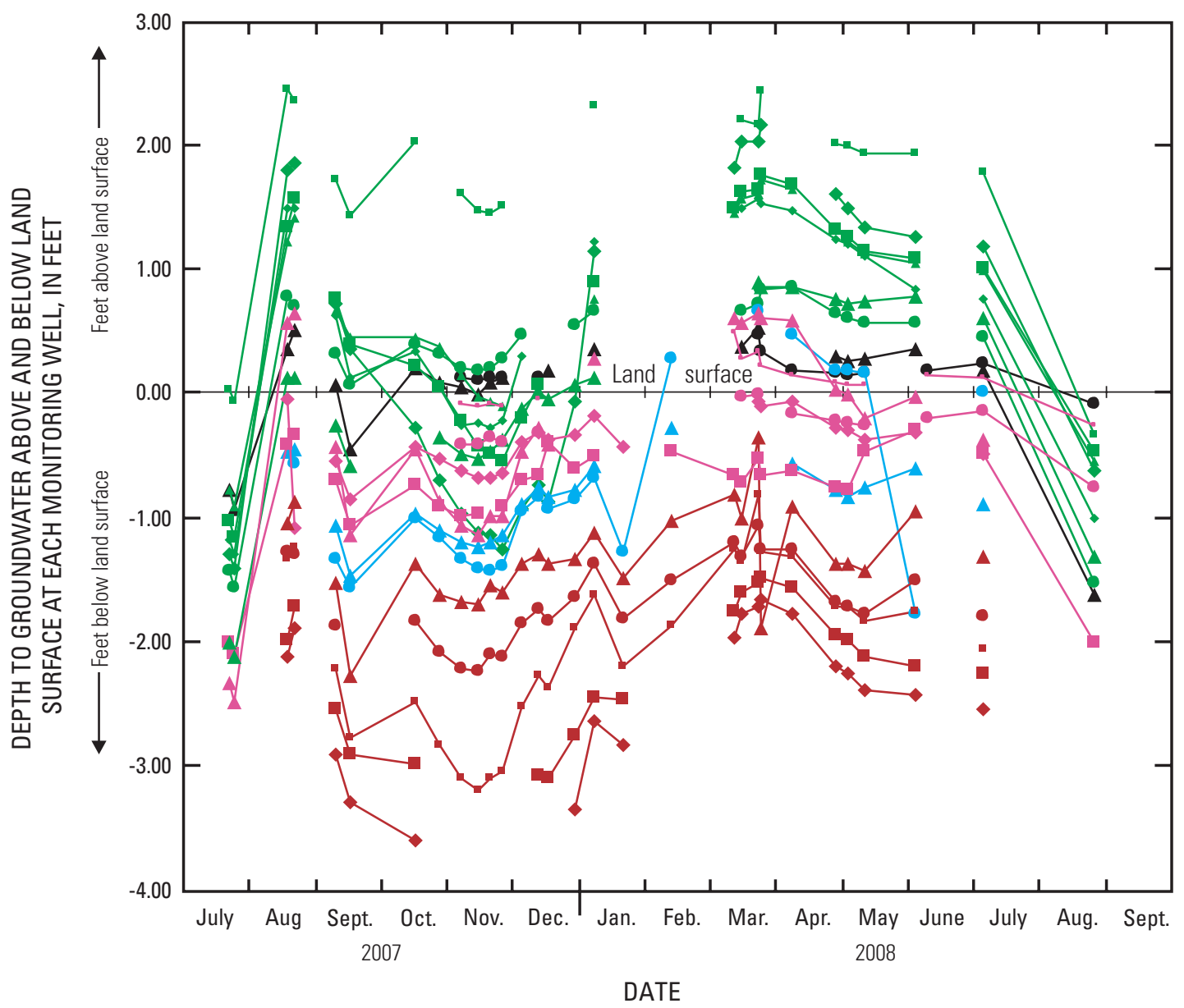

EXPLANATION

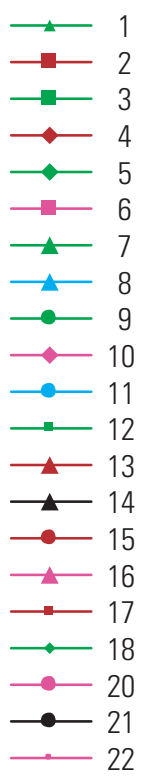

Green symbols are from emergent marshes, black symbols are from sedge meadows, pink symbols are from wet prairies, blue symbols are from wet-mesic prairie, and red symbols are from mesic prairies. Panne (19) is shown on figure 17.

Figure 16. Depth to groundwater in monitoring wells, Spring Bluff Nature Preserve, Chiwaukee Prairie State Natural Area, and Illinois Beach State Park, near Winthrop Harbor and Waukegan, Illinois, July 2007-August 2008. 


\section{Hydroperiods Associated With Different Plant Communities}

Monitoring wells were installed in each of the plant community types and water levels in each community type were grouped (fig. 16). Depth to groundwater during the period of investigation showed distinct differences between the wells located in the various plant communities. Depth to water in wells from each community type are similar and have relatively little overlap with water levels in wells in other plant community types.

Wells in emergent marsh wetlands, the wettest communities found in the study area, had water levels that generally remained near or above land surface for most or all of the year (positive values for depth to water in figure 16 indicate water levels above land surface). Water levels in the emergent marsh areas averaged about $0.5 \mathrm{ft}$ above land surface but were as much as about $2.5 \mathrm{ft}$ above land surface.

Water levels in sedge meadows were as much as $0.75 \mathrm{ft}$ above land surface for several months in late fall through early summer but were 0.5 to $2 \mathrm{ft}$ below land surface in late summer and early fall. This pattern is conducive to sedges, which need dry periods in summer for vegetative propagation.
Water levels in the driest wetland community investigated, wet prairie, averaged about $0.5 \mathrm{ft}$ below land surface. However, water levels in the wet prairie were near, or as much as $0.5 \mathrm{ft}$ above, land surface for several weeks in the late winter and early spring before decreasing to about 0.5 to $1.5 \mathrm{ft}$ below land surface during summer.

Water levels in the nonwetland wet-mesic and mesic prairie communities typically were below land surface during the spring and decreased to more than $2.5 \mathrm{ft}$ below land surface for much of the year. Average water levels in these communities were about $2 \mathrm{ft}$ below land surface. Water levels in the wet-mesic prairie near well 11 were above land surface during the winter and spring 2008, possibly because of wetter than normal weather conditions or the well's location adjacent to a swale that receives water from offsite. The presence of standing water in an area of wet-mesic prairie may indicate a change in the hydrology of this area from its natural conditions.

The water levels from all of the wells in each type of plant community during each measurement date were used to determine the average water level through time for each plant community type (fig. 17). As expected, the trends in the average depth to water for the various plant communities were similar those determined from the individual wells.

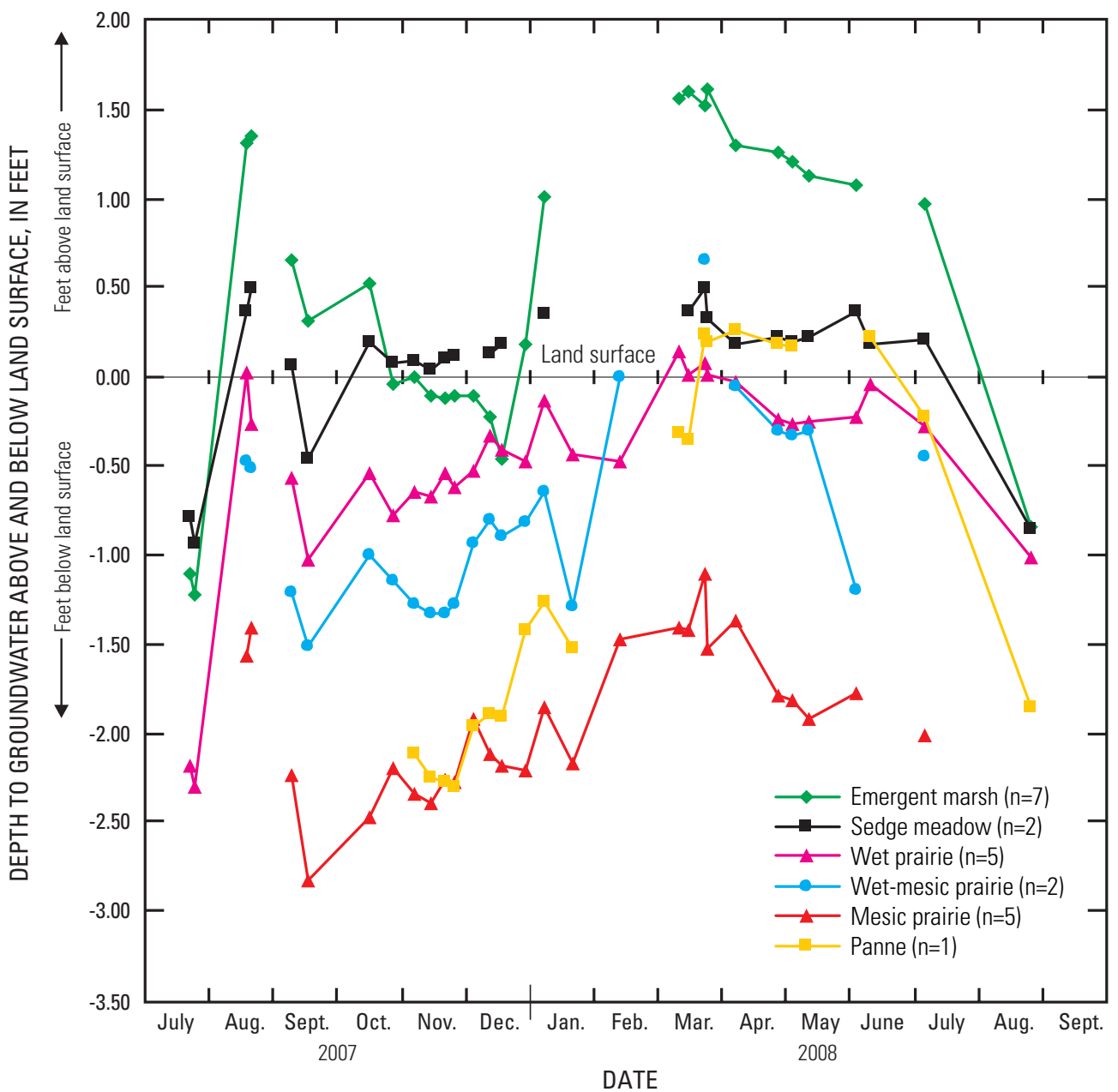

Figure 17. Average depth to groundwater in each type of wetland community, Spring Bluff Nature Preserve, Chiwaukee Prairie State Natural Area, and Illinois Beach State Park, near Winthrop Harbor and Waukegan, Illinois, July 2007August 2008. 
Average water levels in emergent marshes and sedge meadows were above land surface for substantial periods of time. Average water levels in mesic prairie were always below land surface. Average water levels in wet prairies and wet-mesic prairies were typically below land surface but were above land surface for short periods. The only well installed in a panne had standing water levels that were similar to those of a sedge meadow during the spring of 2008, but water levels were similar to those of mesic prairie during the rest of the period of measurement.

Given the unusually wet conditions in August 2007 (table 4), water levels in late summer and fall 2007 may have been atypically high for these communities. Water levels in August 2008 are likely to be more typical. Also, precipitation in much of 2008 was atypically high, likely increasing water levels in these communities and prolonging the inundated periods longer into summer than normal.

\section{Relation of Hydroperiod to Invasive Plant Species}

Analysis indicates that hydroperiods of wetland communities containing invasive plants (for example, Typha spp. and Phragmites australis) were different from those at wetland communities where invasive plants were absent or in low abundance (table 10). Phragmites australis had an importance value greater than 10 at 2 of the 7 sampling locations in the emergent marsh wetlands but were only present (importance value 4.4) at 1 of the 15 sampling locations associated with all other wetland types. Typha spp. were abundant in emergent marsh wetlands (average importance value 19.2) but were much less common or nonexistent in other wetland types. The only emergent wetland sampling location where Typha spp. were not present was well 18 in the CPSNA (fig. 3). The hydroperiod at this emergent wetland is not obviously different from that of other emergent marshes (compare in fig. 16). Given that Typha spp. are found in the same interdunal swale wetland only a few hundred feet away from well 18, it may be that this location will be colonized by Typha spp. at some point in the near future. The current absence of Typha spp. is more likely related to a lag time between hydrologic alteration and the colonization of all available habitat rather than an absence of alteration.

Table 10. Characteristics of vegetation, hydrology, and specific conductance sampled, including summaries by plant community, adjacent to wells 1-22 at the Spring Bluff Nature Preserve, Chiwaukee Prairie State Natural Area, and Illinois Beach State Park, near Winthrop Harbor and Waukegan, Illinois. Locations of wells are shown in figures 2-4.

[SQ, square; SBNP, Spring Bluff Nature Preserve; CPSNA, Chiwaukee Prairie State Natural Area; SUIBSP, Southern Unit Illinois Beach State Park]

\begin{tabular}{|c|c|c|c|c|c|c|c|}
\hline $\begin{array}{c}\text { Well } \\
\text { number }\end{array}$ & Location & $\begin{array}{l}\text { Mean } \\
\text { coefficient of } \\
\text { conserva- } \\
\text { tivism }\end{array}$ & $\begin{array}{c}\text { Native mean } \\
\text { coefficient of } \\
\text { conserva- } \\
\text { tivism }\end{array}$ & $\begin{array}{l}\text { Species } \\
\text { richness } \\
\text { index } \\
\text { (S0 root) }\end{array}$ & $\begin{array}{l}\text { Native } \\
\text { species } \\
\text { richness } \\
\text { index } \\
\text { (SQ root) }\end{array}$ & $\begin{array}{c}\text { Mean } \\
\text { vegetation } \\
\text { wetness }\end{array}$ & $\begin{array}{c}\text { Average } \\
\text { richness } \\
\text { per } 10.75 \\
\text { square feet }\end{array}$ \\
\hline 1 & SBNP & 4.0 & 5.5 & 2.2 & 0.4 & -5.0 & 1.2 \\
\hline 2 & SBNP & 3.7 & 4.4 & 82.7 & 63.0 & .4 & 14.6 \\
\hline 5 & SBNP & 1.0 & 0 & 1.0 & .0 & -5.0 & 1 \\
\hline 6 & SBNP & 5.5 & 5.7 & 79.4 & 77.4 & -2.8 & 14.5 \\
\hline 7 & SBNP & 3.3 & 3.9 & 15.0 & 8.5 & -4.2 & 4.8 \\
\hline 8 & SBNP & 4.7 & 5.3 & 83.9 & 73.9 & -1.0 & 14.4 \\
\hline 9 & SBNP & 2.8 & 5 & 7.4 & 2.2 & -4.0 & 3 \\
\hline 13 & CPSNA & 5.2 & 5.8 & 69.7 & 62.9 & -.4 & 11.6 \\
\hline 14 & CPSNA & 4.9 & 5.2 & 27.6 & 26.3 & -3.8 & 6.5 \\
\hline 15 & CPSNA & 4.4 & 5 & 80.9 & 70.7 & .1 & 13.1 \\
\hline 16 & CPSNA & 6.0 & 6.4 & 32.7 & 35.2 & -3.6 & 8 \\
\hline 17 & CPSNA & 4.5 & 5.6 & 59.4 & 40.8 & .9 & 10.5 \\
\hline 18 & CPSNA & 5.0 & 5 & 9.6 & 9.6 & -5.0 & 3.6 \\
\hline 19 & NUIBSP & 5.6 & 6 & 22.7 & 21.5 & -3.4 & 5.5 \\
\hline 20 & SUIBSP & 6.1 & 6.5 & 82.1 & 78.2 & -3.5 & 13.9 \\
\hline 21 & SUIBSP & 6.8 & 8.1 & 20.4 & 13.9 & -5.0 & 5.9 \\
\hline 22 & SUIBSP & 6.2 & 6.8 & 62.7 & 52.9 & -3.7 & 10.8 \\
\hline
\end{tabular}


Table 10. Characteristics of vegetation, hydrology, and specific conductance sampled, including summaries by plant community, adjacent to wells 1-22 at the Spring Bluff Nature Preserve, Chiwaukee Prairie State Natural Area, and Illinois Beach State Park, near Winthrop Harbor and Waukegan, Illinois. Locations of wells are shown in figures 2-4. - Continued

[SQ, square; SBNP, Spring Bluff Nature Preserve; CPSNA, Chiwaukee Prairie State Natural Area; SUIBSP, Southern Unit Illinois Beach State Park]

\begin{tabular}{|c|c|c|c|c|c|c|}
\hline $\begin{array}{c}\text { Well } \\
\text { number }\end{array}$ & $\begin{array}{l}\text { Species } \\
\text { richness } \\
\text { per well }\end{array}$ & $\begin{array}{l}\text { Native } \\
\text { species } \\
\text { richness } \\
\text { per well }\end{array}$ & $\begin{array}{c}\text { Relative } \\
\text { importance } \\
\text { value } \\
\text { Typha spp. } \\
\text { per well }\end{array}$ & $\begin{array}{c}\text { Relative } \\
\text { importance } \\
\text { value } \\
\text { Phragmites } \\
\text { australis } \\
\text { per well }\end{array}$ & $\begin{array}{l}\text { Average } \\
\text { density of } \\
\text { Typha spp. } \\
\text { per } 10.75 \\
\text { square feet }\end{array}$ & $\begin{array}{c}\text { Average } \\
\text { density of } \\
\text { Phragmites } \\
\text { australis } \\
\text { per } 10.75 \\
\text { square feet }\end{array}$ \\
\hline 1 & 3 & 2 & 35.6 & 0.0 & 10 & 0 \\
\hline 4 & 33 & 27 & .0 & .0 & 0 & 0 \\
\hline 5 & 1 & 0 & 34.2 & .0 & 8 & 0 \\
\hline 6 & 30 & 29 & .0 & .0 & 0 & 0 \\
\hline 7 & 10 & 8 & 16.6 & 12.1 & 4 & 4 \\
\hline 8 & 34 & 30 & .0 & .0 & 0 & 0 \\
\hline 13 & 36 & 32 & .0 & .0 & 0 & 0 \\
\hline 14 & 18 & 17 & .0 & .0 & 0 & 0 \\
\hline 15 & 38 & 34 & .0 & .0 & 0 & 0 \\
\hline 16 & 21 & 20 & .0 & .0 & 0 & 0 \\
\hline 17 & 32 & 26 & .0 & .0 & 0 & 0 \\
\hline 18 & 7 & 7 & .0 & .0 & 0 & 0 \\
\hline 19 & 17 & 16 & .0 & .0 & 0 & 0 \\
\hline 20 & 35 & 33 & .0 & .0 & 0 & 0 \\
\hline 21 & 12 & 10 & 8.8 & .0 & 3 & 0 \\
\hline 22 & 34 & 31 & 6.1 & .0 & 5 & 0 \\
\hline 1 & $\begin{array}{c}\text { Emergent } \\
\text { Marsh }\end{array}$ & 335 & 219 & -0.204 & 1,307 & \\
\hline 2 & Mesic Prairie & 0 & 0 & 6.80 & & \\
\hline 3 & $\begin{array}{c}\text { Emergent } \\
\text { marsh }\end{array}$ & 293 & 214 & -.172 & & \\
\hline 4 & Mesic Prairie & 0 & 0 & .736 & & \\
\hline 5 & $\begin{array}{c}\text { Emergent } \\
\text { Marsh }\end{array}$ & 232 & 172 & -.105 & & \\
\hline 6 & Wet Prairie & 0 & 0 & .246 & & \\
\hline 7 & $\begin{array}{c}\text { Emergent } \\
\text { Marsh }\end{array}$ & 207 & 122 & .025 & 1,047 & \\
\hline 8 & $\begin{array}{c}\text { Mesic Wet } \\
\text { Prairie }\end{array}$ & 0 & 0 & .263 & & \\
\hline 9 & $\begin{array}{c}\text { Emergent } \\
\text { Marsh }\end{array}$ & 329 & 195 & -.078 & & \\
\hline
\end{tabular}


Table 10. Characteristics of vegetation, hydrology, and specific conductance sampled, including summaries by plant community, adjacent to wells 1-22 at the Spring Bluff Nature Preserve, Chiwaukee Prairie State Natural Area, and Illinois Beach State Park, near Winthrop Harbor and Waukegan, Illinois. Locations of wells are shown in figures 2-4. -Continued

[SQ, square; SBNP, Spring Bluff Nature Preserve; CPSNA, Chiwaukee Prairie State Natural Area; SUIBSP, Southern Unit Illinois Beach State Park]

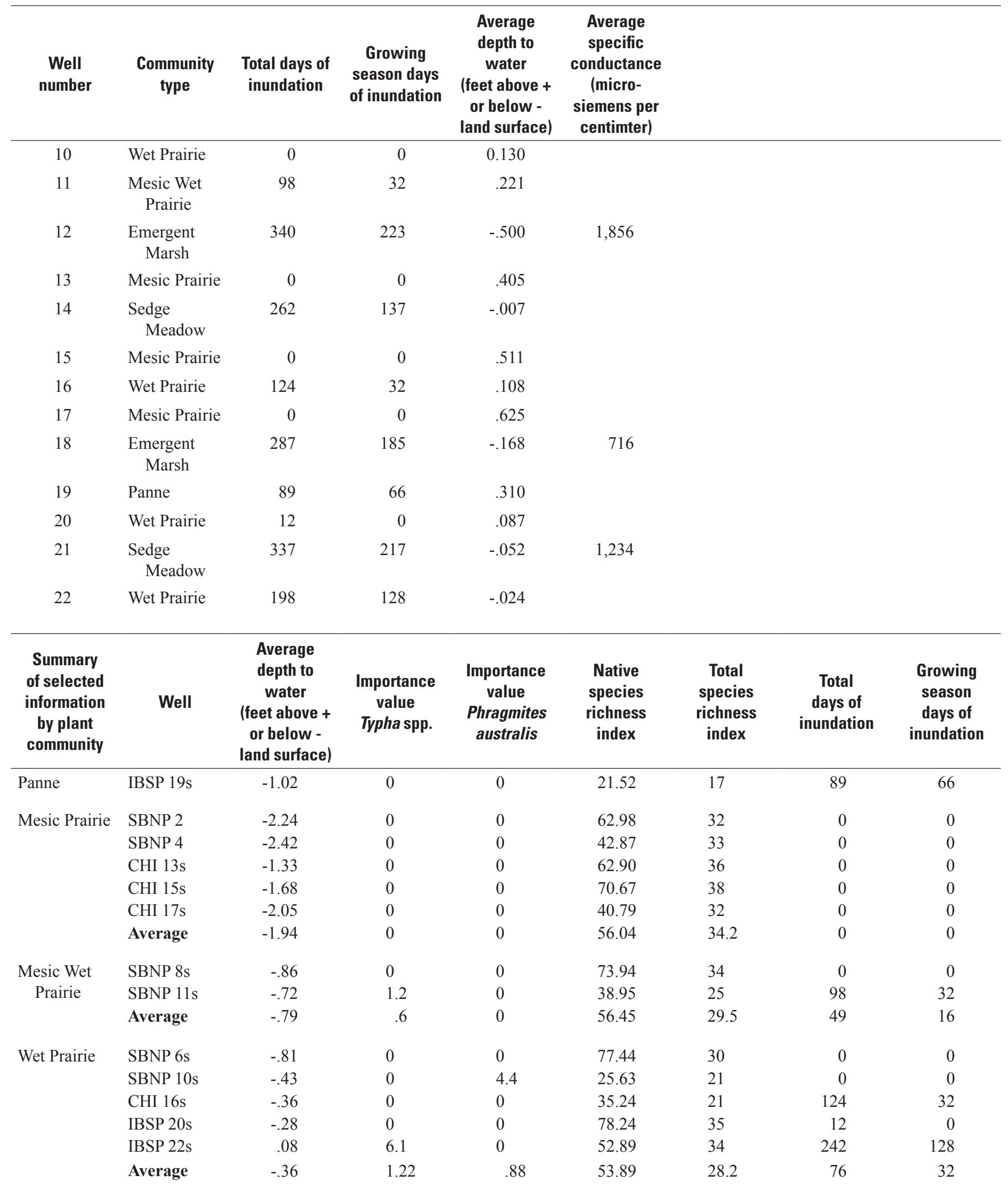


Table 10. Characteristics of vegetation, hydrology, and specific conductance sampled, including summaries by plant community, adjacent to wells 1-22 at the Spring Bluff Nature Preserve, Chiwaukee Prairie State Natural Area, and Illinois Beach State Park, near Winthrop Harbor and Waukegan, Illinois. Locations of wells are shown in figures 2-4. - Continued

[SQ, square; SBNP, Spring Bluff Nature Preserve; CPSNA, Chiwaukee Prairie State Natural Area; SUIBSP, Southern Unit Illinois Beach State Park]

\begin{tabular}{clccccccc}
\hline $\begin{array}{c}\text { Summary } \\
\text { of selected } \\
\text { information } \\
\text { by plant } \\
\text { community }\end{array}$ & Well & $\begin{array}{c}\text { Average } \\
\text { depth to } \\
\text { water } \\
\text { (feet above + } \\
\text { or below - } \\
\text { land surface) }\end{array}$ & $\begin{array}{c}\text { Importance } \\
\text { value } \\
\text { Typha spp. }\end{array}$ & $\begin{array}{c}\text { Importance } \\
\text { value } \\
\text { Phragmites } \\
\text { australis }\end{array}$ & $\begin{array}{c}\text { Native } \\
\text { species } \\
\text { richness } \\
\text { index }\end{array}$ & $\begin{array}{c}\text { Total } \\
\text { species } \\
\text { richness } \\
\text { index }\end{array}$ & $\begin{array}{c}\text { Total } \\
\text { days of } \\
\text { inundation }\end{array}$ & $\begin{array}{c}\text { Growing } \\
\text { season } \\
\text { days of } \\
\text { inundation }\end{array}$ \\
\hline $\begin{array}{c}\text { Sedge } \\
\text { Meadow }\end{array}$ & CHI 14s & 0.02 & 0 & 0 & 26.31 & 18 & 282 & 137 \\
& IBSP 21s & .17 & 8.8 & 0 & 13.85 & 12 & 381 & 217 \\
& Average & .10 & 4.4 & 0 & 20.08 & 15 & 332 & 177 \\
Emergent & SBNP 1s & .67 & 35.6 & 0 & .35 & 3 & 382 & 219 \\
Marsh & SBNP 3s & .57 & 3.6 & 0 & 16.19 & 12 & 338 & 214 \\
& SBNP 5s & .35 & 34.2 & 0 & .00 & 10 & 276 & 172 \\
& SBNP 7s & -.08 & 16.6 & 12.1 & 8.49 & 10 & 237 & 122 \\
& SBNP 9s & .26 & 23.5 & 10.9 & 2.17 & 6 & 359 & 195 \\
& SBNP 12s & 1.64 & 20.9 & 0 & .85 & 3 & 387 & 223 \\
& CHI 18s & .55 & 0 & 0 & 9.58 & 7 & 319 & 185 \\
\hline
\end{tabular}

\section{Surface-Water Quality}

Surface-water quality data consist of discrete measurements of field parameters, nutrients, chloride, and sediment collected during the periodic sampling events; continuous measurements of field parameters at selected locations; and intensive sediment sampling during storm events.

\section{Field Parameters}

Discrete measurements of temperature, dissolved oxygen, $\mathrm{pH}$, and specific conductance were made in the field during each of the periodic water sampling events because these parameters are somewhat unstable and may change during transport of bottled samples to the laboratory. Analysis and interpretation of field parameters collected during the periodic sampling events is limited by the lack of data from all possible sites, owing to battery problems with the multiparameter instrument. However, patterns in values of many of the field parameters (not only discrete measurements collected during the periodic sampling events but also the continuous measurements collected from the dataloggers) provided insight into the chemistry of the study area.

\section{Temperature}

Water temperature is an important variable affecting many stream and wetland processes, such as the decomposition of organic matter (Webster and others, 1995) and the development of aquatic organisms (Sweeney, 1984;
Allan, 1995). Water temperature affects the type of habitat and the organisms that can survive within the ecosystem.

As expected, water temperatures measured during periodic sampling varied with atmospheric temperature. Measured temperatures were highest during the summer months (about $20-24^{\circ} \mathrm{C}$ during June and August 2007) and lowest during the late fall (about $1-4^{\circ} \mathrm{C}$ in November 2007) (table 11). The intermittent presence of ice at all of the measurement stations during winter, when discrete temperature measurements were not made, indicates surface-water temperatures were near $0^{\circ} \mathrm{C}$ during much of the winter.

Water temperatures in the study area varied by as much as $8.5^{\circ} \mathrm{C}$ between measurement locations during any individual periodic sampling event. Spatial differences in temperature during individual sampling events are primarily owing to variations in air temperature and the intensity of solar radiation at the time and place of the measurements and perhaps variations in the depth of water and amount of groundwater discharge.

Continuous temperature measurements showed the expected cooling during winter and warming during summer (fig. 18). However, the water in the wetlands at gages W3 and 12 did not freeze, probably because of the amount of standing surface water or the presence of relatively warm groundwater discharge. The data also show substantial warming events during early to mid-January, when runoff and snowmelt may have occurred. The large magnitude of the change in surface-water temperature at gages 7 and 18 relative to other sites is related to the smaller amount of standing water at these gages being more affected by the diurnal changes in temperature, which heated and cooled the surface water at the gages. 
Table 11. Field-parameter measurements in surface water at gages in the vicinity of the Spring Bluff Nature Preserve, Chiwaukee Prairie State Natural Area, and Illinois Beach State Park, near Winthrop Harbor and Waukegan, Illinois, May 31, 2007May 13,2008 . Locations of gages are shown in figures $2-4$.

[--, measurement not made]

\begin{tabular}{|c|c|c|c|c|c|c|c|c|}
\hline \multirow[b]{2}{*}{$\begin{array}{l}\text { Staff } \\
\text { gage }\end{array}$} & \multicolumn{4}{|c|}{ 05/31/2007 } & \multicolumn{4}{|c|}{ 06/27/2007 } \\
\hline & $\begin{array}{c}\text { Temperature } \\
\text { (degrees } \\
\text { Celsius) }\end{array}$ & $\begin{array}{l}\text { Dissolved } \\
\text { oxygen } \\
\text { (percent } \\
\text { saturation) }\end{array}$ & $\begin{array}{c}\text { pH } \\
\text { (standard } \\
\text { units) }\end{array}$ & $\begin{array}{c}\text { Specific } \\
\text { conductance } \\
\text { (microsie- } \\
\text { mens per } \\
\text { centimeter) }\end{array}$ & $\begin{array}{c}\text { Temperature } \\
\text { (degrees } \\
\text { Celsius) }\end{array}$ & $\begin{array}{l}\text { Dissolved } \\
\text { oxygen } \\
\text { (percent } \\
\text { saturation) }\end{array}$ & $\begin{array}{c}\text { pH } \\
\text { (standard } \\
\text { units) }\end{array}$ & $\begin{array}{c}\text { Specific } \\
\text { conductance } \\
\text { (microsie- } \\
\text { mens per } \\
\text { centimeter) }\end{array}$ \\
\hline DD1 & 17.7 & 89.05 & 7.67 & 1,165 & 20.2 & 78.69 & 8.09 & 1,155 \\
\hline DD3 & -- & -- & -- & -- & -- & -- & -- & -- \\
\hline DD4 & -- & -- & -- & -- & 20.1 & 53.9 & 7.54 & 1,611 \\
\hline W1 & -- & -- & -- & -- & -- & -- & -- & -- \\
\hline W3 & 20.7 & 27.2 & 7.22 & 1,098 & 24.4 & 33.77 & 7.35 & 1,070 \\
\hline W4 & -- & -- & -- & -- & 18.2 & 42 & 6.89 & 1,248 \\
\hline DR1 & -- & -- & -- & -- & -- & -- & -- & -- \\
\hline DR2 & -- & -- & -- & -- & -- & -- & -- & -- \\
\hline \multirow[t]{2}{*}{ DR3 } & -- & -- & -- & -- & -- & -- & -- & -- \\
\hline & \multicolumn{4}{|c|}{ 08/29/2007 } & \multicolumn{4}{|c|}{ 09/18/2007 } \\
\hline $\begin{array}{l}\text { Staff } \\
\text { gage }\end{array}$ & $\begin{array}{c}\text { Temperature } \\
\text { (degrees } \\
\text { Celsius) }\end{array}$ & $\begin{array}{l}\text { Dissolved } \\
\text { oxygen } \\
\text { (percent } \\
\text { saturation) }\end{array}$ & $\begin{array}{c}\text { pH } \\
\text { (standard } \\
\text { units) }\end{array}$ & $\begin{array}{c}\text { Specific } \\
\text { conductance } \\
\text { (microsie- } \\
\text { mens per } \\
\text { centimeter) }\end{array}$ & $\begin{array}{c}\text { Temperature } \\
\text { (degrees } \\
\text { Celsius) }\end{array}$ & $\begin{array}{c}\text { Dissolved } \\
\text { oxygen } \\
\text { (percent } \\
\text { saturation) }\end{array}$ & $\begin{array}{c}\text { pH } \\
\text { (standard } \\
\text { units) }\end{array}$ & $\begin{array}{c}\text { Specific } \\
\text { conductance } \\
\text { (microsie- } \\
\text { mens per } \\
\text { centimeter) }\end{array}$ \\
\hline DD1 & 20.7 & 91 & 7.37 & 1,310 & 15.9 & 92.9 & 8.04 & 1,179 \\
\hline DD2 & -- & -- & -- & -- & 15.9 & 41.15 & 7.58 & 1,002 \\
\hline DD3 & 20.0 & 52.8 & 7.18 & 1,253 & -- & -- & -- & -- \\
\hline DD4 & -- & -- & -- & -- & 15.9 & 25.42 & 7.73 & 1,369 \\
\hline SG1 & -- & -- & -- & -- & 18.2 & 23.89 & 7.41 & 957 \\
\hline W1 & 21.2 & 38.23 & 7.46 & 1,079 & 14.8 & 23.43 & 7.32 & 1,080 \\
\hline W2 & -- & -- & -- & -- & 14.1 & 48.71 & 7.47 & 664 \\
\hline W3 & 24.5 & 72.34 & 7.51 & 1,265 & 16.2 & 64.49 & 7.65 & 1,122 \\
\hline W4 & 18.1 & 19.52 & 7.06 & 1,720 & 13.9 & 21.82 & 7.21 & 1,125 \\
\hline DR1 & 21.5 & 93.68 & 7.97 & 1,762 & 15.8 & 90.37 & 7.73 & 1,531 \\
\hline DR2 & 22.2 & 28.09 & 7.84 & 1,428 & 14.5 & 29.06 & 6.54 & 1,139 \\
\hline \multirow[t]{2}{*}{ DR3 } & 25.2 & 143.7 & 8.2 & 1,178 & 17.6 & 101.31 & 7.14 & 833 \\
\hline & \multicolumn{4}{|c|}{$11 / 27 / 2007$} & \multicolumn{4}{|c|}{$04 / 02 / 2008$} \\
\hline $\begin{array}{l}\text { Staff } \\
\text { gage }\end{array}$ & $\begin{array}{c}\text { Temperature } \\
\text { (degrees } \\
\text { Celsius) }\end{array}$ & $\begin{array}{l}\text { Dissolved } \\
\text { oxygen } \\
\text { (percent } \\
\text { saturation) }\end{array}$ & $\begin{array}{c}\text { pH } \\
\text { (standard } \\
\text { units) }\end{array}$ & $\begin{array}{c}\text { Specific } \\
\text { conductance } \\
\text { (microsie- } \\
\text { mens per } \\
\text { centimeter) }\end{array}$ & $\begin{array}{c}\text { Temperature } \\
\text { (degrees } \\
\text { Celsius) }\end{array}$ & $\begin{array}{l}\text { Dissolved } \\
\text { oxygen } \\
\text { (percent } \\
\text { saturation) }\end{array}$ & $\begin{array}{c}\text { pH } \\
\text { (standard } \\
\text { units) }\end{array}$ & $\begin{array}{c}\text { Specific } \\
\text { conductance } \\
\text { (microsie- } \\
\text { mens per } \\
\text { centimeter) }\end{array}$ \\
\hline DD1 & 1.9 & 85.6 & 7.63 & 1,178 & 4.2 & 97.2 & 7.81 & 1,089 \\
\hline DD2 & 1.1 & 33.2 & 6.76 & 955 & -- & -- & -- & -- \\
\hline DD3 & -- & -- & -- & -- & 4.7 & 85.6 & 7.82 & 974 \\
\hline DD4 & 3.9 & 111.4 & 7.66 & 1,404 & 8.6 & 96.1 & 7.97 & 2,406 \\
\hline
\end{tabular}


Table 11. Field-parameter measurements in surface water at gages in the vicinity of the Spring Bluff Nature Preserve, Chiwaukee Prairie State Natural Area, and Illinois Beach State Park, near Winthrop Harbor and Waukegan, Illinois, May 31, 2007May 13, 2008. Locations of gages are shown in figures 2-4. - Continued

$[--$, measurement not made $]$

\begin{tabular}{|c|c|c|c|c|c|c|c|c|}
\hline \multirow[b]{2}{*}{$\begin{array}{l}\text { Staff } \\
\text { gage }\end{array}$} & \multicolumn{4}{|c|}{$11 / 27 / 2007$} & \multicolumn{4}{|c|}{$04 / 02 / 2008$} \\
\hline & $\begin{array}{c}\text { Temperature } \\
\text { (degrees } \\
\text { Celsius) }\end{array}$ & $\begin{array}{l}\text { Dissolved } \\
\text { oxygen } \\
\text { (percent } \\
\text { saturation) }\end{array}$ & $\begin{array}{c}\text { pH } \\
\text { (standard } \\
\text { units) }\end{array}$ & $\begin{array}{c}\text { Specific } \\
\text { conductance } \\
\text { (microsie- } \\
\text { mens per } \\
\text { centimeter) }\end{array}$ & $\begin{array}{c}\text { Temperature } \\
\text { (degrees } \\
\text { Celsius) }\end{array}$ & $\begin{array}{l}\text { Dissolved } \\
\text { oxygen } \\
\text { (percent } \\
\text { saturation) }\end{array}$ & $\begin{array}{c}\text { pH } \\
\text { (standard } \\
\text { units) }\end{array}$ & $\begin{array}{c}\text { Specific } \\
\text { conductance } \\
\text { (microsie- } \\
\text { mens per } \\
\text { centimeter) }\end{array}$ \\
\hline W1 & 4.2 & 50.6 & 7.05 & 933 & 10.3 & 94.2 & 7.96 & 863 \\
\hline W3 & 3.8 & 79.2 & 6.51 & 1,144 & 9.2 & 84.5 & 7.18 & 1,157 \\
\hline W4 & 3.0 & 40.2 & 6.76 & 955 & 3.8 & 64.0 & 7.79 & 980 \\
\hline DR1 & 2.4 & 84.3 & 7.89 & 1,257 & 8.0 & 96.1 & 8.21 & 1,419 \\
\hline DR2 & 3.5 & 31.5 & 7.77 & 1,072 & 5.9 & 88.5 & 7.91 & 1,216 \\
\hline DR3 & 2.1 & 101.8 & 8.36 & 860 & 7.4 & 95.3 & 7.35 & 978 \\
\hline $\begin{array}{l}\text { Staff } \\
\text { gage }\end{array}$ & $\begin{array}{c}\text { Temperature } \\
\text { (degrees } \\
\text { Celsius) }\end{array}$ & $\begin{array}{l}\text { Dissolved } \\
\text { oxygen } \\
\text { (percent } \\
\text { saturation) }\end{array}$ & $\begin{array}{c}\text { pH } \\
\text { (standard } \\
\text { units) }\end{array}$ & $\begin{array}{c}\text { Specific } \\
\text { conductance } \\
\text { (microsie- } \\
\text { mens per } \\
\text { centimeter) }\end{array}$ & & & & \\
\hline DD1 & 10.6 & 99.4 & 6.97 & 1,021 & & & & \\
\hline DD2 & 14.5 & 95.4 & 8.05 & 960 & & & & \\
\hline DD3 & 12.3 & 62.5 & 7.59 & 882 & & & & \\
\hline DD4 & 11.9 & 78.5 & 7.47 & 1,819 & & & & \\
\hline SG1 & 15.8 & 96.1 & 8.07 & 1,438 & & & & \\
\hline DR3 & 17.5 & -- & -- & -- & & & & \\
\hline
\end{tabular}




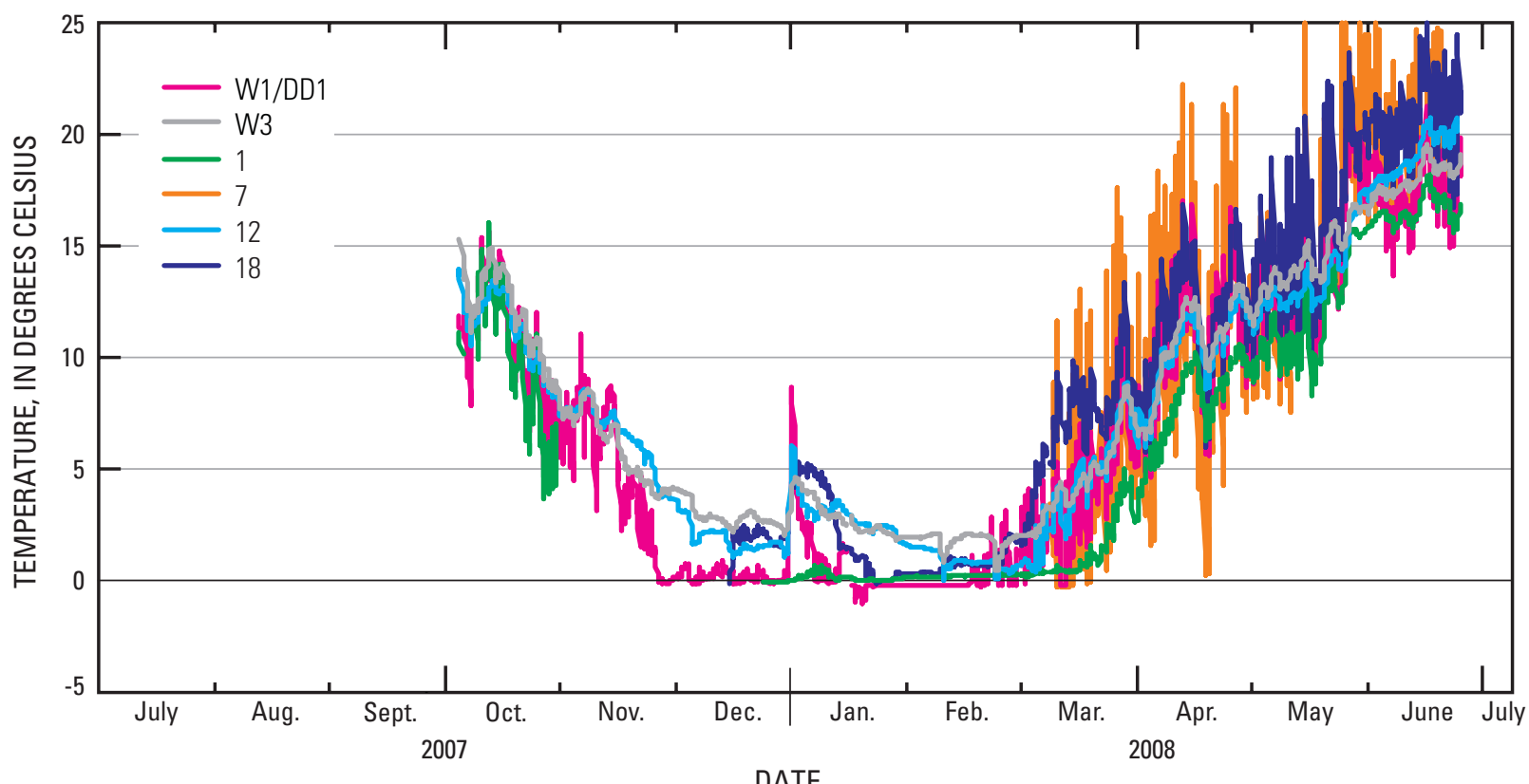

Figure 18. Surface-water temperatures recorded at well locations in the vicinity of the Spring Bluff Nature Preserve, Winthrop Harbor, Illinois, September 2007-June 2008.

\section{Dissolved Oxygen}

Dissolved oxygen is essential to aerobic respiration, and many chemical and biological reactions depend on the presence of oxygen in water. The main factors affecting the concentration of dissolved oxygen in aquatic ecosystems are the exchange of dissolved oxygen between the water body and the atmosphere, photosynthetic production of oxygen by green aquatic plants, and consumption of oxygen by bacteria and other aquatic organisms during the breakdown of organic matter (Radtke and others, 1998; Boyd, 2000).

Saturation levels of dissolved oxygen ranged from more than 100 percent of saturation at gage DR3 during several periodic sampling events to less than 25 percent of saturation at gages SG1 and W4 during August and September 2007 (table 11). Saturation with respect to dissolved oxygen was highest where there was active water movement, such as in the upland areas (DD1, DD4, DR1) during times of high flow (April and May 2008), because water movement enhances the exchange of oxygen between water and the atmosphere. Saturation levels of dissolved oxygen were lowest where there was little or no water movement, higher temperatures, and substantial decay of organic matter. These processes predominate in the wetland areas (W4, DR2, W2) and stagnant ditches (SG1), because decomposition of organic matter consumes dissolved oxygen, the lack of water movement restricts the exchange of oxygen with the atmosphere, and higher water temperatures reduce the solubility of oxygen in water (Stumm and Morgan, 1981).
$\mathrm{pH}$

Many reactions that affect water quality are $\mathrm{pH}$-dependent. The $\mathrm{pH}$ of water is a measure of the effective hydrogenion concentration: $\mathrm{pH}$ standard unit values are the negative base-10 logarithm of hydrogen-ion activity, in moles per liter (Radtke and others, 1998). The $\mathrm{pH}$ is affected by interrelated chemical reactions that either produce or consume hydrogen ions (Hem, 1992). The $\mathrm{pH}$ of natural water is an indicator of the status of these chemical reactions. The $\mathrm{pH}$ of pure water at $25^{\circ} \mathrm{C}$ is 7.00 . The $\mathrm{pH}$ can be affected by the presence of dissolved gases - particularly carbon dioxide, which can reduce $\mathrm{pH}$ by creating carbonic acid.

The discrete $\mathrm{pH}$ values measured during periodic sampling range from 6.51 to 8.41 standard units (table 11). These values are within the Illinois Pollution Control Board (IPCB) criteria for the range of values within the Lake Michigan Basin of 6.5-9.0 standard units (Illinois Pollution Control Board, 1978). $\mathrm{pH}$ values show no consistent trends through time or with location.

\section{Specific Conductance}

Specific conductance is a measure of the electrical conductance of a unit volume of water at $25^{\circ} \mathrm{C}$ and is a function of the combined concentrations of dissolved ions in the water. As a consequence, specific conductance is generally a good indicator of the overall dissolved solids within the area of 
investigation. Discrete specific-conductance values measured during the periodic sampling ranged from 664 to $2,406 \mu \mathrm{S} / \mathrm{cm}$ during the investigation (table 11), with consistently higher values measured on August 29, 2007. The higher specific conductance during August may reflect the addition of dissolved solids to, or the remobilization of dissolved solids within, the wetlands during the large precipitation events that occurred in the days and weeks before this sampling event.

Specific conductance was highest at the upland gages (DR1, DD1, DD4) and tended to decrease toward Lake Michigan, indicating that dissolved solids concentration tends to be highest as it enters the study area (especially at DD4) and declines with increasing distance through the wetland complex. This pattern is most apparent along the Dead River, where specific conductance showed a consistent decrease for gages DR1-DR3. In the NUIBSP, specific conductance showed a consistent decrease from gage DD4 to gages SG1 and W4, and from gages SG1 and W4 to gage DD3. In the SBNP, specific conductance consistently decreased from gage $\mathrm{DD} 1$ to gages DD2 and $\mathrm{W} 3$, and from gages DD2 and $\mathrm{W} 3$ to gage W2. These patterns indicate that physical and chemical processes occurring in the wetland complex are improving overall water quality before it enters Lake Michigan.

Specific conductance obtained from the continuous measurements collected by using the multiparameter dataloggers demonstrates several trends (fig. 19). These patterns are summarized below.

First, several stations had seasonal trends whereby specific conductance is higher in winter months than spring or fall, and they additionally had obvious short-term fluctuations - on the order of hours to days. These trends likely are owing to the presence of road salt in urban runoff during the winter months, which can cause sharp increases in specific conductance during at least some snowmelt events, as well as smaller increases during winter that can last on the order of weeks to months. Stations showing both long-term and short-term increases in winter include well 1 and gage W1. These stations are near roadways or along major drainageways that may carry urban-runoff-impacted surface water into and through the wetland complex.

Second, there are long-term differences among stations. Stations 12 and W3 had specific conductances that are much higher than those at other continuously monitored stations, averaging more than $1,500 \mu \mathrm{S} / \mathrm{cm}$ for the majority of the year, and they remained high except for short-term (hours to days) declines that are likely the result of precipitation diluting the dissolved solids in the surface water. The cause of the high specific conductance at these gages is not known with certainty.

Third, the lowest recorded values for specific conductance were in the CPSNA, at the stations most distant from surface inflows. This pattern indicates that runoff may be the source of higher specific conductance in the coastal wetland complex.
Fourth, intermittent downward spikes in specific conductance were recorded for all stations. These downward spikes lasted hours to several days and likely were caused by dilution resulting from precipitation or snowmelt occurring near the gage that was not impacted by road salt from urban runoff.

Invalid data resulting from identified problems such as dry or frozen instruments, inaccurate calibrations that were identified during post deployment calibration checks, and similar quality-control issues were removed. However, some apparent data inconsistencies were not resolved during quality-control checks of the data because a cause could not be identified. These inconsistencies include repetitive decreases noted after servicing of instruments (see March and May 2008 at loggers W3 and H12) and rapid increases or decreases in value for the duration of a deployment between calibrations (for instance, H1 in March 2008). Trends and conclusions cannot be identified from these data, and, although not excluded from the graphs, will not be considered further.

\section{Turbidity}

Turbidity was continuously recorded at gages W1, W3, and DD1. Turbidity is a measure of the amount light dispersion by particles suspended in water. Turbidity is proportional to suspended particulate content (Lewis, 1996), although specific correlations cannot be made without calibration. Suspended sediment in surface water may restrict sunlight penetration or negatively affect vegetation in other ways, including smothering native vegetation when it settles or increasing the load of nutrients and contaminants that are associated with sediment. The suspended-sediment content in surface runoff may be elevated in areas with substantial agricultural or urban land use relative to natural land use because of increased erosion owing to reductions in the amount of vegetation land cover, more voluminous runoff, and more rapid streamflows.

Continuous recording water-quality instruments were installed to identify trends in turbidity and, by inference, suspended-sediment concentration in the vicinity of the SBNP (fig. 20). Surface water flows from Dead Dog Creek at gage DD1 at the western edge of the coastal complex eastward toward W3, in an emergent marsh just in the west-central part of the SBNP, then in part northward towards W1. No substantial increases in turbidity were observed at gage W1 during October 2007-January 2008, indicating that influent sediment plumes may be highly attenuated at this point in the flow pathway. For this reason, the instrument at gage W1 was moved to gage DD1 in January 2008 for the purpose of documenting turbidity at the entrance to the preserve. Several spikes in turbidity lasting several hours to days were periodically observed at gage DD1 in conjunction with precipitation events. Turbidity spikes at gage W3 typically were small and showed moderate correlation with precipitation events. Spikes in turbidity not associated with precipitation or snowmelt events are assumed to be the result of sediment disturbance by visitors or animals. 


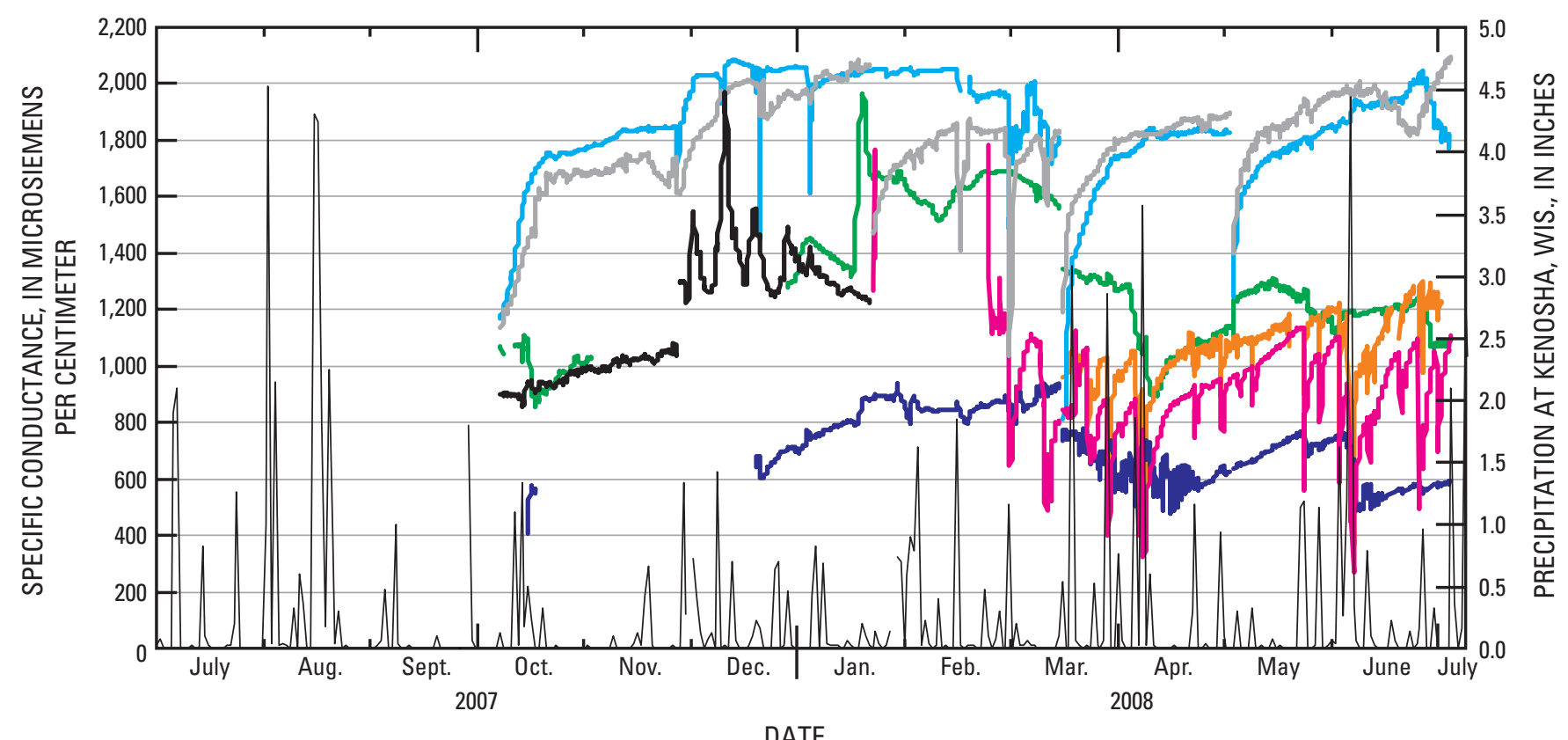

EXPLANATION

Specific conductance

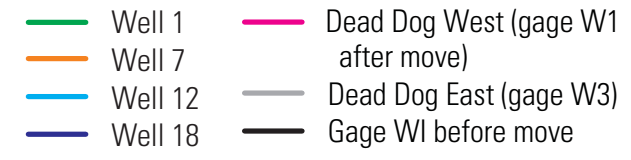

— Precipitation

Figure 19. Specific conductance of surface water and amount of precipitation at selected gages and well locations in the vicinity of the Spring Bluff Nature Preserve, Winthrop Harbor, Illinois, July 2007-July 2008.

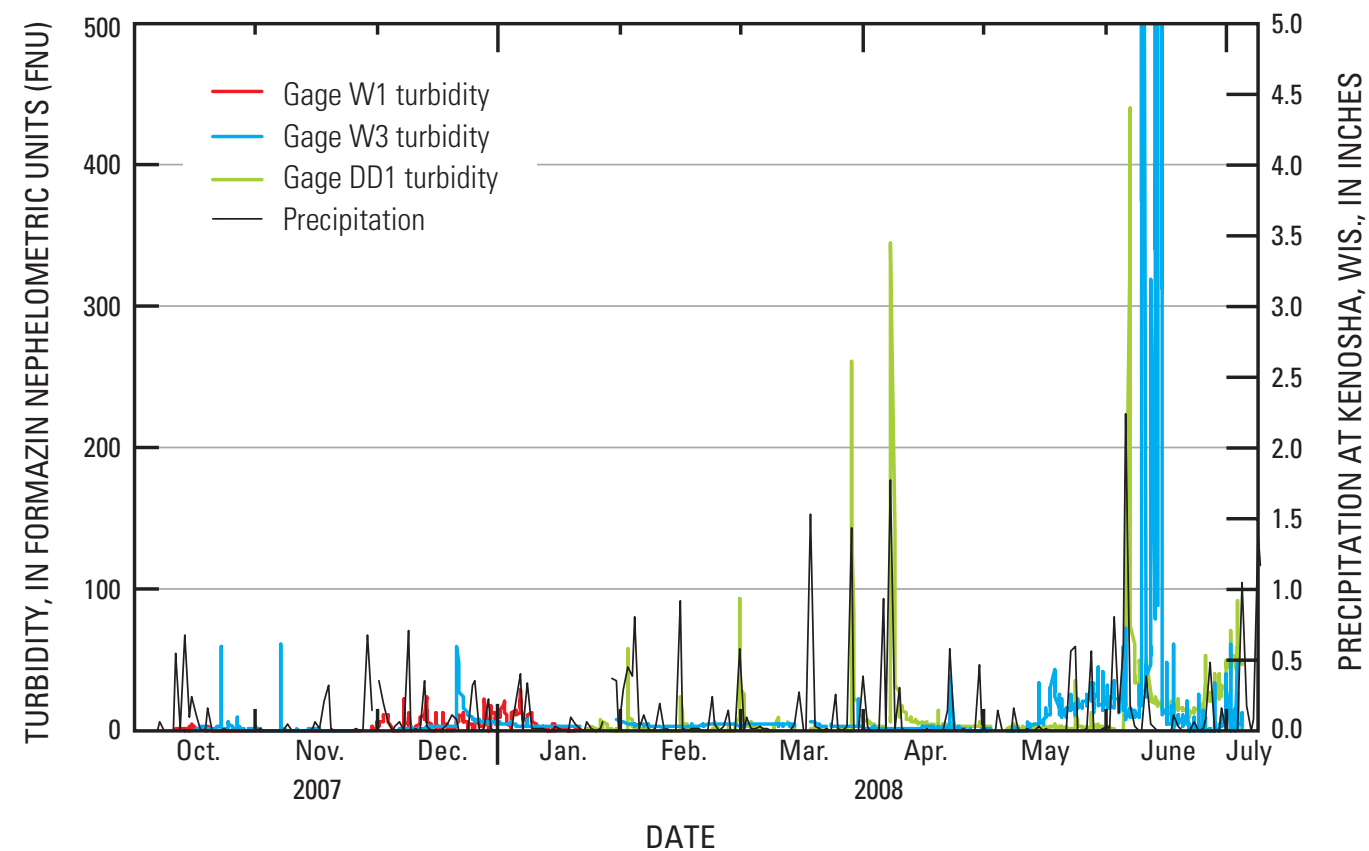

Figure 20. Turbidity and precipitation in Dead Dog Creek and wetlands in the vicinity of the Spring Bluff Nature Preserve, Winthrop Harbor, Illinois, October 2007-July 2008. 


\section{Chloride}

In this region, naturally occurring concentrations of chloride in precipitation, surface water, and shallow groundwater are low. Chloride is a component of road salt that is applied to roads in the area for deicing. It also is present at elevated concentrations in wastewater, including septic discharge, although most of the residences in the watersheds draining the coastal complex are not on septic systems. Chloride is a soluble element, and its relative concentration can often be used to infer the presence and extent of urban runoff (Feth, 1981). Plants have varying levels of tolerance to chloride, and excessive concentrations of chloride can limit growth of some plants, especially native freshwater species that are not adapted to higher chloride levels. High chloride levels are associated with reductions in plant diversity in wetlands and facilitate the dominance of a few tolerant species (Panno and others, 1999).

Concentrations of chloride in samples of surface water ranged from 45 to $400 \mathrm{mg} / \mathrm{L}$ during the investigation (table 12). These concentrations were below the IPCB Water Quality Criterion for the Lake Michigan Basin of $500 \mathrm{mg} / \mathrm{L}$. Samples collected at the points of outflow to the lake did, however, exceed the IPCB standard for chloride concentration in the open water of Lake Michigan of $12 \mathrm{mg} / \mathrm{L}$.

Table 12. Concentrations of laboratory-determined constituents in surface water at gages in the vicinity of the Spring Bluff Nature Preserve, Chiwaukee Prairie State Natural Area, and Illinois Beach State Park, near Winthrop Harbor and Waukegan, Illinois, May 31, 2007-May 13, 2008. Locations of gages are shown in figures 2-4.

[mg/L, milligrams per liter; <, less than reporting level; e, estimated concentration; --, sample not collected; bold denotes sample/duplicate]

\begin{tabular}{|c|c|c|c|c|c|c|c|c|}
\hline Gage & \multicolumn{4}{|c|}{ 05/31/2007 } & \multicolumn{4}{|c|}{ 06/27/2007 } \\
\hline DD1 & 0.31 & 0.036 & 140 & 40 & 0.34 & 0.037 & 140 & 150 \\
\hline DD3 & $<.06$ & .015 & 120 & 54 & $<.06$ & .016 & 82 & 240 \\
\hline W1 & $.03 \mathrm{e}$ & .015 & 100 & -- & $.032 \mathrm{e}$ & .015 & 97 & -- \\
\hline W3 & $<.06$ & .053 & 130 & -- & $<.06$ & .025 & 120 & -- \\
\hline W4 & $<.06$ & .027 & 120 & -- & $<.06$ & .119 & 110 & -- \\
\hline DR1 & .7 & .042 & 140 & 54 & .3 & .045 & 83 & 25 \\
\hline
\end{tabular}

\begin{tabular}{|c|c|c|c|c|c|c|c|c|}
\hline \multirow[b]{2}{*}{ Gage } & \multicolumn{4}{|c|}{ 07/30/2007 } & \multicolumn{4}{|c|}{ 08/29/2007 } \\
\hline & $\begin{array}{l}\text { Nitrate plus } \\
\text { nitrite as } \\
\text { nitrogen, } \\
\text { mg/L }\end{array}$ & $\begin{array}{c}\text { Phosphorus, } \\
\text { mg/L }\end{array}$ & $\begin{array}{c}\text { Chloride, } \\
\text { mg/L }\end{array}$ & $\begin{array}{c}\text { Suspended } \\
\text { sediment, } \\
\text { mg/L }\end{array}$ & $\begin{array}{l}\text { Nitrate plus } \\
\text { nitrite as } \\
\text { nitrogen, } \\
\text { mg/L }\end{array}$ & $\begin{array}{c}\text { Phosphorus, } \\
\mathrm{mg} / \mathrm{L}\end{array}$ & $\begin{array}{c}\text { Chloride, } \\
\text { mg/L }\end{array}$ & $\begin{array}{c}\text { Suspended } \\
\text { sediment, } \\
\text { mg/L }\end{array}$ \\
\hline DD1 & $0.31 / 0.31$ & $0.042 / 0.042$ & $140 / 140$ & 166 & 0.318 & 0.029 & 100 & 40 \\
\hline DD3 & -- & -- & -- & -- & .06 & .018 & 99 & 51 \\
\hline DD4 & -- & -- & -- & -- & $<.06$ & .018 & 160 & 34 \\
\hline W1 & -- & -- & -- & -- & $.041 \mathrm{e}$ & .032 & 63 & -- \\
\hline W3 & $<.06$ & .029 & 160 & -- & $<.06$ & .025 & 92 & -- \\
\hline W4 & $<.06$ & .054 & 130 & -- & $<.06$ & .12 & 120 & -- \\
\hline DR1 & .437 & .040 & 190 & 45 & .543 & .041 & 170 & 100 \\
\hline DR2 & $<.06$ & .027 & 110 & 22 & $<.06$ & .039 & 125 & 64 \\
\hline DR3 & $<.06$ & .009 & 60 & 6 & $<.06$ & .008 & 93 & 60 \\
\hline
\end{tabular}


Table 12. Concentrations of laboratory-determined constituents in surface water at gages in the vicinity of the Spring Bluff Nature Preserve, Chiwaukee Prairie State Natural Area, and Illinois Beach State Park, near Winthrop Harbor and Waukegan, Illinois, May 31, 2007-May 13, 2008. Locations of gages are shown in figures 2-4. - Continued

$[\mathrm{mg} / \mathrm{L}$, milligrams per liter; $<$, less than reporting level; e, estimated concentration; --, sample not collected; bold denotes sample/duplicate]

\begin{tabular}{|c|c|c|c|c|c|c|c|c|}
\hline Gage & \multicolumn{4}{|c|}{ 09/18/2007 } & \multicolumn{4}{|c|}{$11 / 27 / 2007$} \\
\hline DD1 & 0.202 & 0.021 & 130 & 55 & $<0.04$ & 0.012 & 140 & 140 \\
\hline DD3 & -- & -- & -- & -- & -- & -- & -- & -- \\
\hline W1 & $<.06$ & .01 & 94 & -- & $.023 \mathrm{e}$ & .01 & 92 & -- \\
\hline W2 & -- & -- & -- & -- & -- & -- & -- & -- \\
\hline W3 & $<.06$ & .013 & 130 & -- & $<.04$ & .008 & 140 & -- \\
\hline W4 & $<.06$ & .204 & 120 & -- & $<.04$ & .23 & 95 & 9 \\
\hline DR3 & \multicolumn{4}{|c|}{ 04/02/2008 } & \multicolumn{4}{|c|}{ 05/13/2008 } \\
\hline Gage & $\begin{array}{l}\text { Nitrate plus } \\
\text { nitrite as } \\
\text { nitrogen, } \\
\text { mg/L }\end{array}$ & $\begin{array}{c}\text { Phosphorus, } \\
\text { mg/L }\end{array}$ & $\begin{array}{c}\text { Chloride, } \\
\text { mg/L }\end{array}$ & $\begin{array}{l}\text { Suspended } \\
\text { sediment, } \\
\text { mg/L }\end{array}$ & $\begin{array}{c}\text { Nitrate plus } \\
\text { nitrite as } \\
\text { nitrogen, } \\
\text { mg/L }\end{array}$ & $\begin{array}{c}\text { Phosphorus, } \\
\mathrm{mg} / \mathrm{L}\end{array}$ & $\begin{array}{c}\text { Chloride, } \\
\text { mg/L }\end{array}$ & $\begin{array}{c}\text { Suspended } \\
\text { sediment, } \\
\text { mg/L }\end{array}$ \\
\hline DD1 & 1.37 & 0.023 & 100 & 24 & $0.105 / 0.101$ & 0.011/0.009 & $130 / 130$ & 60 \\
\hline DD3 & .268 & .013 & 91 & 3 & $<.04$ & .011 & 94.5 & 6 \\
\hline DD4 & 1.71 & .013 & 350 & 46 & .096 & .012 & 380 & 26 \\
\hline W1 & $.037 \mathrm{e}$ & .016 & 45 & 12 & $<.04$ & .010 & 91 & 48 \\
\hline DR3 & .454 & .008 & 110 & 22 & $<.04$ & .007 & 170 & 30 \\
\hline
\end{tabular}

Chloride concentrations in surface water were highest at the sampling locations along the bluffs entering the wetland complex and generally declined toward Lake Michigan (fig. 21; table 12), a pattern that is consistent with the trends in specific conductance. Higher chloride concentrations in the samples near the bluff indicate that this water is affected by urban runoff in the watershed, including road salt. The lower chloride concentrations in the eastern part of the wetland complex indicate that the urban runoff has been attenuated, most likely by dilution from precipitation and groundwater discharge to surface water within the wetlands. Chloride concentrations in samples collected on May 13, 2008, are representative of the typical spatial patterns in chloride concentrations during the investigation and are discussed because they constitute the largest synoptic data set (fig. 21).

The concentration of chloride entering the SBNP in Dead Dog Creek at gage DD1 during May 13, 2008, was $130 \mathrm{mg} / \mathrm{L}$ (fig. 21). The chloride concentration in the western part of the SBNP at the next downstream gage (W3) was similar to the average concentrations for the gage during the investigation $(121 \mathrm{mg} / \mathrm{L})$. The chloride concentration in the eastern part of the SBNP at the point where it drains to Lake Michigan (gage W2) was $110 \mathrm{mg} / \mathrm{L}$. Chloride concentrations decreased by 19 percent from gage DD1 to gage W2 on this date. 


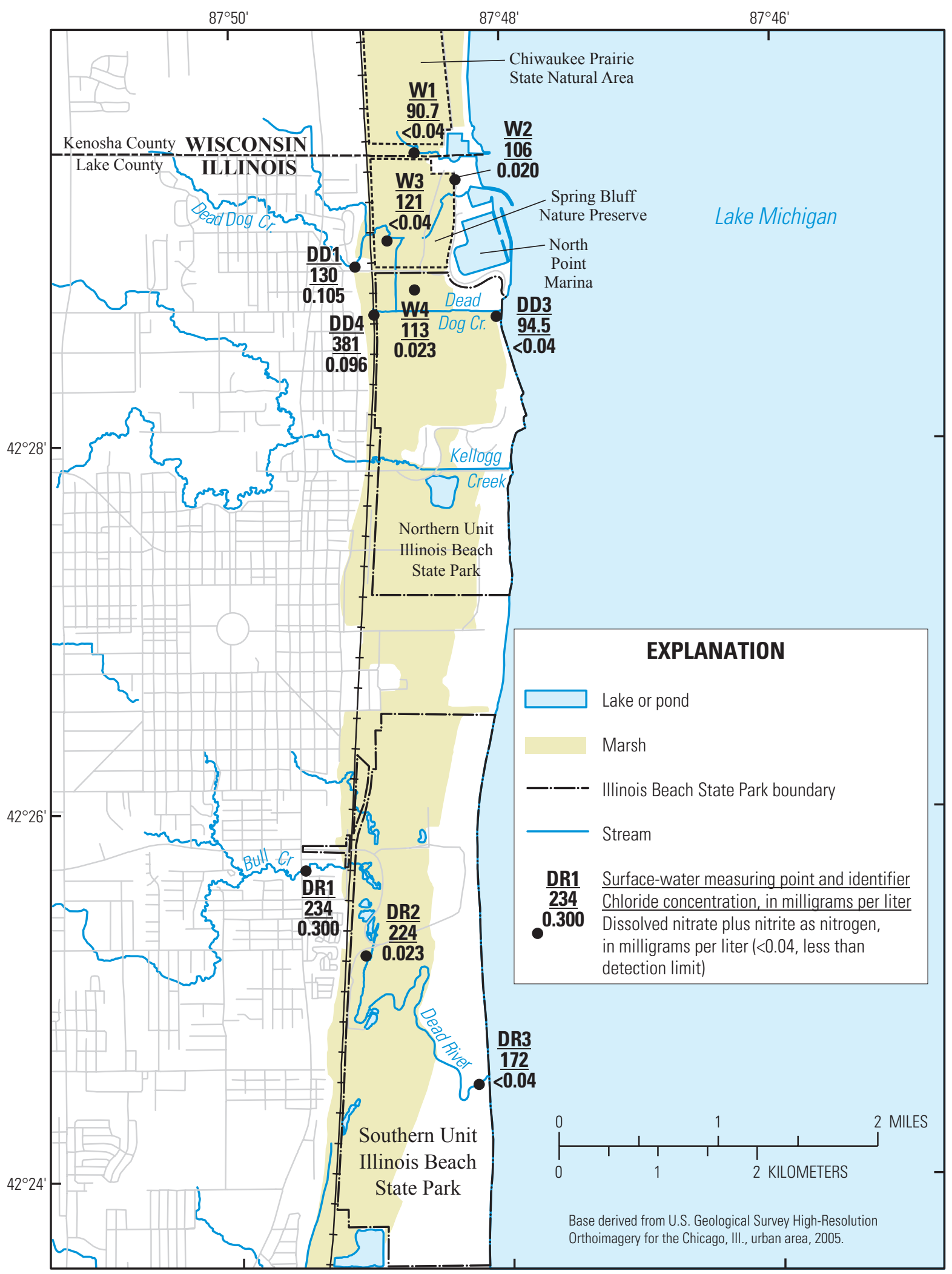

Figure 21. Concentrations of chloride and dissolved nitrate plus nitrite as nitrogen in surface water in the vicinity of the Spring Bluff Nature Preserve, Chiwaukee Prairie State Natural Area, and Northern and Southern Units of the Illinois Beach State Park near Winthrop Harbor and Waukegan, Illinois, May 13, 2008. 
The concentration of chloride in surface water entering the NUIBSP from the drainage at gage DD4 during May 13, 2008, was about $380 \mathrm{mg} / \mathrm{L}$ (fig. 21). The chloride concentration in the central part of the NUIBSP at the next downstream gage (W4) was substantially lower (about $110 \mathrm{mg} / \mathrm{L}$ ). The chloride concentration in the eastern part of the NUIBSP at the discharge point to Lake Michigan (gage DD3) was $95 \mathrm{mg} / \mathrm{L}$. Chloride concentrations decreased by about 75 percent from gage DD4 to gage DD3 on this date.

The concentration of chloride entering the SUIBSP in Bull Creek at gage DR1 during May 13, 2008, was 320 mg/L (fig. 21). The chloride concentration in the western part of the SUIBSP at the next downstream gage (DR2) was $220 \mathrm{mg} / \mathrm{L}$. The chloride concentration in the eastern part of the SUIBSP at the point where the Dead River drains to Lake Michigan (gage DR3) was $170 \mathrm{mg} / \mathrm{L}$. Chloride concentrations decreased by almost 50 percent from gage DR1 to gage DR3 on this date.

Chloride concentrations in surface water at the SBNP gages were similar through time during most of the investigation but were somewhat lower during the August 29, 2007, and April 2, 2008, sampling events (table 12). The low chloride concentrations measured on these dates likely was the result of dilution by recent rainfall (August) or rainfall and snowmelt (April).

Chloride concentrations in surface water at the NUIBSP gages were similar through time at gages DD3 and W4 during most of the investigation but showed a small overall decrease at gage W4 during the investigation (table 12). Chloride concentrations at gage DD4 were usually the highest measured in the study area but were substantially lower during the JuneNovember 2007 sampling events than during the spring 2007 and 2008 sampling events. The high chloride concentrations at gage DD4 during the spring months likely reflect the relatively large contribution of urban runoff in this small, highly urbanized, watershed. In particular, the transport of wintertimeapplied road salt by the spring rains apparently added to the chloride concentrations at this time. The comparatively low chloride concentrations detected during the summer and fall of 2007 also may have been owing to a relatively higher contribution from groundwater inflow to the stream. Groundwater likely has lower concentrations of chloride in comparison to stormwater runoff at gage DD4.

Chloride concentrations in Bull Creek and the Dead River at the SUIBSP gages were variable during most of the investigation but were highest or above average at all of the gages during the May 15, 2008, sampling event (table 12). The high chloride concentrations in the water during this sampling event may reflect the high percentage of water in this large, moderately urbanized watershed that received springtime runoff of previously applied road salt and other urban effects as discussed above.

\section{Nitrogen and Phosphorous}

Nitrogen and phosphorous are essential nutrients for plant growth. They are components of fertilizers that can be leached into agricultural or urban runoff. Plants take up these nutrients from soil and water during the growing season and release them when the plants die and decay. Relatively large concentrations of nutrients associated with anthropogenically affected runoff can result in increased growth of algae and plant species that are adapted to store additional nutrients in the form of carbohydrates, resulting in increased plant vigor and spread at the expense of less competitive plant species that are adapted to nutrient-limited or nutrient-poor conditions (Woo and Zedler, 2002; Kercher and Zedler, 2004b).

Concentrations of nitrate plus nitrite as nitrogen (hereafter referred to as "nitrate") in surface water in the study area varied from below the reporting level of 0.04 to $1.7 \mathrm{mg} / \mathrm{L}$ during the investigation (table 12). Nitrate concentrations did not exceed State of Illinois criterion for Finished Water, nor did they exceed State criterion for concentrations in the open water of Lake Michigan, both of which are $10 \mathrm{mg} / \mathrm{L}$ (Illinois Pollution Control Board, 1978).

Nitrate concentrations in surface water typically were highest along the bluffs entering the wetland complex at gages DD1, DD4, and DR1 and generally decreased toward Lake Michigan (fig. 21). The higher nitrate concentrations in the western part of the wetland complex likely result from agricultural and urban runoff affected by fertilizers and animal and septic waste. The lower nitrate concentrations in the eastern part of the wetland complex likely reflect the combined effects of dilution, uptake of nitrogen by plants and microbiota, and the biologic transformation of nitrogen compounds (denitrification) within the wetlands. Nitrate concentrations in samples collected on May 13, 2008, indicate a typical pattern in nitrate concentrations during the investigation and are discussed below because they represent the largest synoptic nitrate data set.

The concentration of nitrate in Dead Dog Creek entering the SBNP at gage DD1 during May 13, 2008, was $0.105 \mathrm{mg} / \mathrm{L}$ (fig. 21; table 12). Nitrate was not detected in the central part of the SBNP at gages W3 and W1 at a reporting level of $0.04 \mathrm{mg} / \mathrm{L}$. Nitrate was detected at an estimated concentration of $0.02 \mathrm{mg} / \mathrm{L}$ (concentrations below the reporting level are estimated) in the northeastern part of the SBNP where it drains to Lake Michigan (gage W2). Nitrate concentrations decreased by about 80 percent from gage DD1 to gage W2 on this date. 
The concentration of nitrate in surface water entering the NUIBSP from the culvert monitored by gage DD4 during May 13, 2008, was $0.096 \mathrm{mg} / \mathrm{L}$ (fig. 21; table 12). The nitrate concentration in the central part of the NUIBSP at the next downstream gage (W4) was estimated to be $0.023 \mathrm{mg} / \mathrm{L}$. The nitrate concentration in the eastern part of the NUIBSP at the outflow to Lake Michigan (gage DD3) was below the reporting level of $0.04 \mathrm{mg} / \mathrm{L}$. Nitrate concentrations decreased by at least 60 percent from gage DD4 to gage DD3 on this date.

The concentration of nitrate entering the SUIBSP in Bull Creek at gage DR1 during May 13, 2008, was $0.30 \mathrm{mg} / \mathrm{L}$

(fig. 21; table 12). The nitrate concentration in the western part of the SUIBSP at the next downstream gage (DR2) was estimated at $0.023 \mathrm{mg} / \mathrm{L}$. The nitrate concentration in the eastern part of the SUIBSP at the point where the Dead River drains to Lake Michigan (gage DR3) was below the reporting level of $0.04 \mathrm{mg} / \mathrm{L}$. Nitrate concentrations decreased by at least 85 percent from gage DR1 to gage DR3 on this date.

Nitrate concentrations at the gages were similar through time during most of the investigation but were substantially higher during the April 2, 2008, sampling than during the other sampling events at every sampling point (table 12). The high nitrate concentrations in samples collected on this date likely were the result of nitrate released from fall fertilizer applications and the decay of organic matter within the watershed (including within the wetlands) during the winter months, which was transported to the coastal complex in stormwater and snowmelt.

Concentrations of dissolved phosphorous in surface water ranged from an estimated concentration of $0.005 \mathrm{mg} / \mathrm{L}$ to $0.23 \mathrm{mg} / \mathrm{L}$ during the investigation (table 12). Several samples collected at the points of outflow to Lake Michigan exceeded IPCB standards for total phosphorus concentration in the open waters of Lake Michigan of $0.007 \mathrm{mg} / \mathrm{L}$. Phosphorus, unlike most forms of nitrogen, is strongly sorbed to sediment particles and, therefore, phosphorous concentrations often are positively correlated with suspended-sediment concentrations (Hem, 1992). As a consequence, dissolved phosphorous concentrations from filtered samples (such as were collected for this investigation) typically are lower than total phosphorous concentrations that would be present in unfiltered samples. Therefore, the dissolved phosphorous data indicate that total phosphorous concentrations in surface-water discharging from the wetland complex may pose a risk to Lake Michigan.
Dissolved phosphorous concentrations in samples collected on April 2, 2008, are typical of the patterns in the study area during the investigation. These data are discussed because they are the largest representative data set (table 12). May 13, 2008, data are not discussed because dissolved phosphorus concentrations on that date tended to be atypically low at gages DD1, DR1, and DR2, which resulted in somewhat atypical patterns in dissolved phosphorous concentrations in the SBNP and SUIBSP. The fact that dissolved phosphorous concentrations were low on May 13, 2008, whereas dissolved nitrate concentrations were high, indicates either that the nutrients are derived in part from different sources or that the proportions of total and dissolved phosphorous differed on May 13 from those during other sampling events.

The concentration of dissolved phosphorous in Dead Dog Creek entering the SBNP at gage DD1 during April 2, 2008, was $0.023 \mathrm{mg} / \mathrm{L}$ (fig. 22). The dissolved phosphorous concentrations in the central part of the SBNP at gages W3 and W1 were 0.015 and $0.016 \mathrm{mg} / \mathrm{L}$, respectively. No phosphorous data are available for this date at gage W2. Dissolved phosphorous concentrations were about 35 percent lower between gages DD1 and W3 on this date. Patterns in dissolved phosphorous concentrations were variable in the SBNP. On most of the sampling dates, a pattern of decreasing concentrations between gages DD1 and W1 and W3 was observed, indicating that the SBNP typically is a sink for dissolved phosphorous (table 12). However, on some sampling dates, concentrations were similar throughout the area or higher at gage $\mathrm{W} 1$ or W3, indicating that processes in the SBNP could release dissolved phosphorous to the water column on occasion.

The concentration of dissolved phosphorous entering the NUIBSP at gage DD4 on April 2, 2008, was $0.013 \mathrm{mg} / \mathrm{L}$ (fig. 22). The dissolved phosphorous concentration in the central part of the NUIBSP at gage (W4), which is not part of the ditch system connecting DD4 and DD3, was substantially higher $(0.039 \mathrm{mg} / \mathrm{L})$. The phosphorous concentration in the eastern part of the NUIBSP at the outflow to Lake Michigan (gage DD3) was identical to that at gage DD4. These patterns in phosphorous concentrations were consistent with the patterns in the NUIBSP during the other sampling events.

The concentration of dissolved phosphorous entering the SUIBSP in Bull Creek at gage DR1 on April 2, 2008, was $0.022 \mathrm{mg} / \mathrm{L}$ (fig. 22). The dissolved phosphorous concentration in the western part of the SUIBSP at the next downstream gage (DR2) was $0.018 \mathrm{mg} / \mathrm{L}$. The dissolved phosphorous concentration in the eastern part of the SUIBSP at the outflow of Dead River to Lake Michigan (gage DR3) was $0.008 \mathrm{mg} / \mathrm{L}$. Dissolved phosphorous concentrations decreased by about 66 percent from gage DR1 to gage DR3 on this date, which is consistent with the results of the other sampling events in the SUIBSP. 


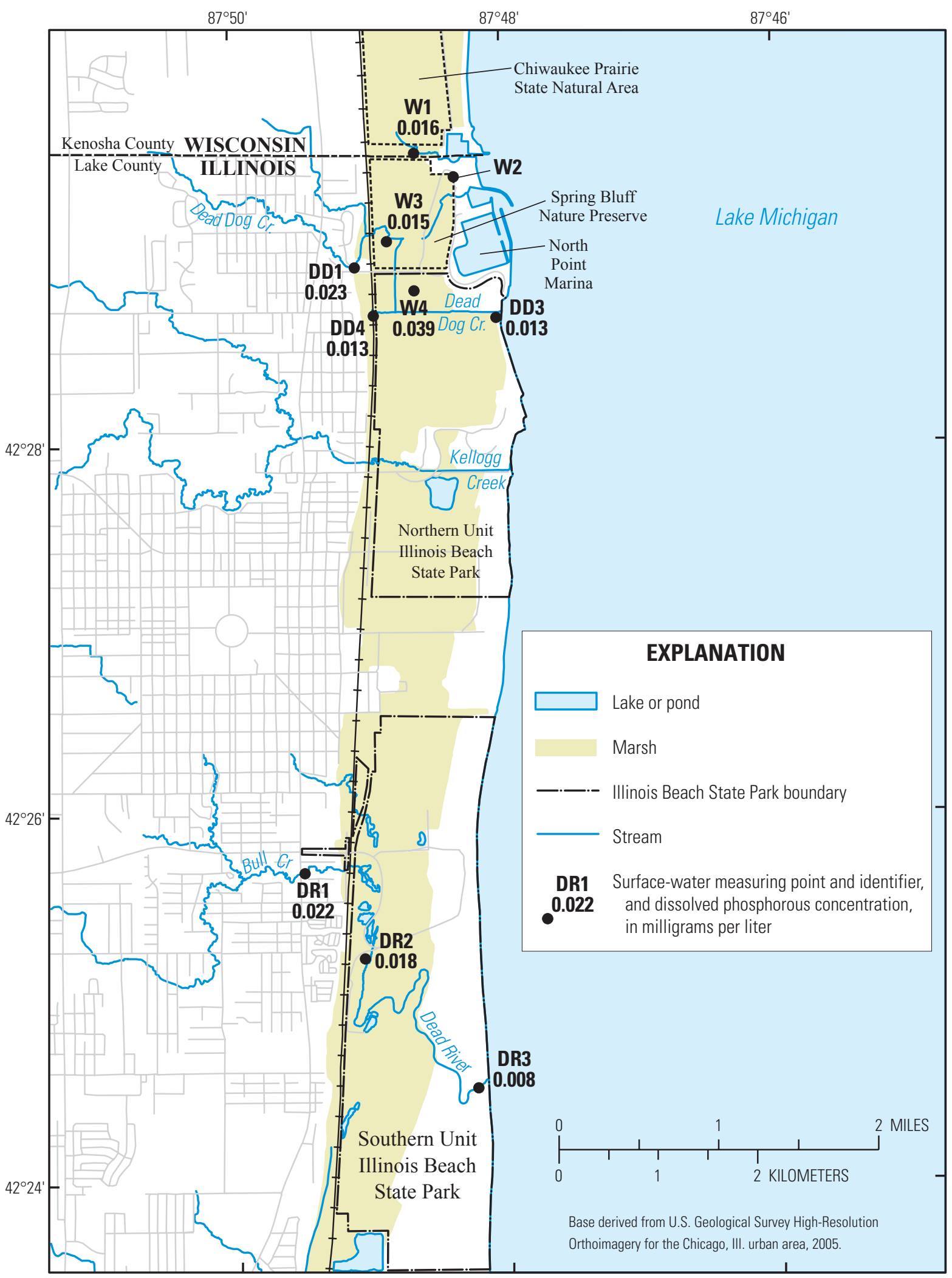

Figure 22. Concentrations of dissolved phosphorous in surface water in the vicinity of the Spring Bluff Nature Preserve, Chiwaukee Prairie State Natural Area, and Northern and Southern Units of the Illinois Beach State Park near Winthrop Harbor and Waukegan, Illinois, April 2, 2008. 
Dissolved phosphorous concentrations in the SBNP showed an overall decrease through time during May 31, 2007-November 27, 2007, at gages DD1 and W3 and were similar to fall 2007 concentrations for the subsequent sampling events (table 12). Except for a high value during the August 29, 2007, sampling event, dissolved phosphorous concentrations at gage $\mathrm{W} 1$ showed little variation. The trends in dissolved phosphorous concentrations at gages DD1 and W3 may be the result of increased phosphorous uptake by plants in the watershed during the 2007 growing season, likely after fertilizer application in residential areas during the spring, and dilution by precipitation during the spring 2008 sampling events. Uptake of phosphorous within the wetland complex during the growing season by plants and microbiota, as well as mineral precipitation and sorption onto sediments, also may have played a role. The relatively high dissolved phosphorous concentration in the sample collected at gage $\mathrm{W} 1$ during the August 29, 2007, sampling event may reflect the release of dissolved phosphorous from organic matter and pore water in sediments within parts of the wetland, perhaps exacerbated by mechanical disturbance to the plants and sediments in this area from flow owing to the record precipitation in the days and weeks preceding the sampling. Dissolved phosphorous concentrations in the NUIBSP were relatively stable through time at gages DD3 and DD4 (table 12). Concentrations at gage W4 increased overall from 0.027 to $0.23 \mathrm{mg} / \mathrm{L}$ during the 2007 sampling events, then were less than $0.05 \mathrm{mg} / \mathrm{L}$ during the 2008 sampling events. The increasing dissolved phosphorous concentrations in the samples from gage W4 during the spring and summer months may reflect the release of phosphorous from sediments and decaying plants, perhaps in combination with a lack of dilution from incoming surface flow to this part of the wetland complex. The comparatively low dissolved phosphorous concentrations in the spring 2007 and 2008 samples may reflect dilution by spring runoff and precipitation.

Dissolved phosphorous concentrations at the SUIBSP gages showed an overall decrease through time during the investigation (table 12). Decreases were greatest at upstream gage DR1, moderate at gage DR2, and smallest at downstream gage DR3. These trends may be related to increasing uptake of phosphorous by plants in the watershed and the coastal complex during the 2007 growing season, likely after fertilizer application in the spring, and dilution by precipitation during the spring 2008 sampling events. Dissolved phosphorous concentrations in the samples from gages DD1 and DR1 are highly correlated $\left(\mathrm{R}^{2}=0.83\right)$, indicating that the timing and processes affecting phosphorous inputs to the Bull Creek Watershed (presumably fertilizer application and uptake by plants) are similar to those affecting inputs to the Dead Dog Creek Watershed.

\section{Suspended Sediment}

Insufficient data were collected to create a sediment budget for the wetland complex, and the data are inadequate to evaluate whether or not this area is a net source or trap for sediment under routine conditions. However, samples collected in the northern part of the study area at the SBNP and the NUIBSP during the routine periodic sampling indicate that suspended-sediment concentrations in the creeks entering the wetlands at gages DD1 and DD4 typically were less than the concentrations exiting the wetland complex at gages DD3 and W2 (table 12). Samples collected at the SUIBSP during the periodic sampling events indicate that suspended-sediment concentrations in Bull Creek at gage DR1, before it enters the wetland complex, typically were greater than the concentrations within the wetlands at gage DR2 by about a factor of 2 . Sediment concentrations at gage DR2 typically were similar to those exiting the Dead River into Lake Michigan at gage DR3.

Suspended-sediment concentrations showed no relation to stream discharge (Pearson product moment correlation coefficient of 0.01) during the periodic sampling events. However, sediment concentrations were higher in the creeks and ditches where flow was active than in the parts of the wetland complex where there was minimal flow.

Suspended-sediment concentrations from intensive sampling on Dead Dog Creek at gage DD1 during and after precipitation events on August 23, September 25, October 14, 2007, March 26-April 2, 2008, and April 11, 2008 , indicate that large changes in sediment concentrations occurred over a period of hours during and after these events (fig. 23). Although not necessarily highly correlated over the entire event $\left(\mathrm{R}^{2}=0.58\right)$, large increases in suspendedsediment concentration at gage DD1 were associated with large increases in water level (and therefore discharge) at the stream. Large decreases in suspended-sediment concentration were associated with the large decreases in water level (and discharge) after the water level peaked. 


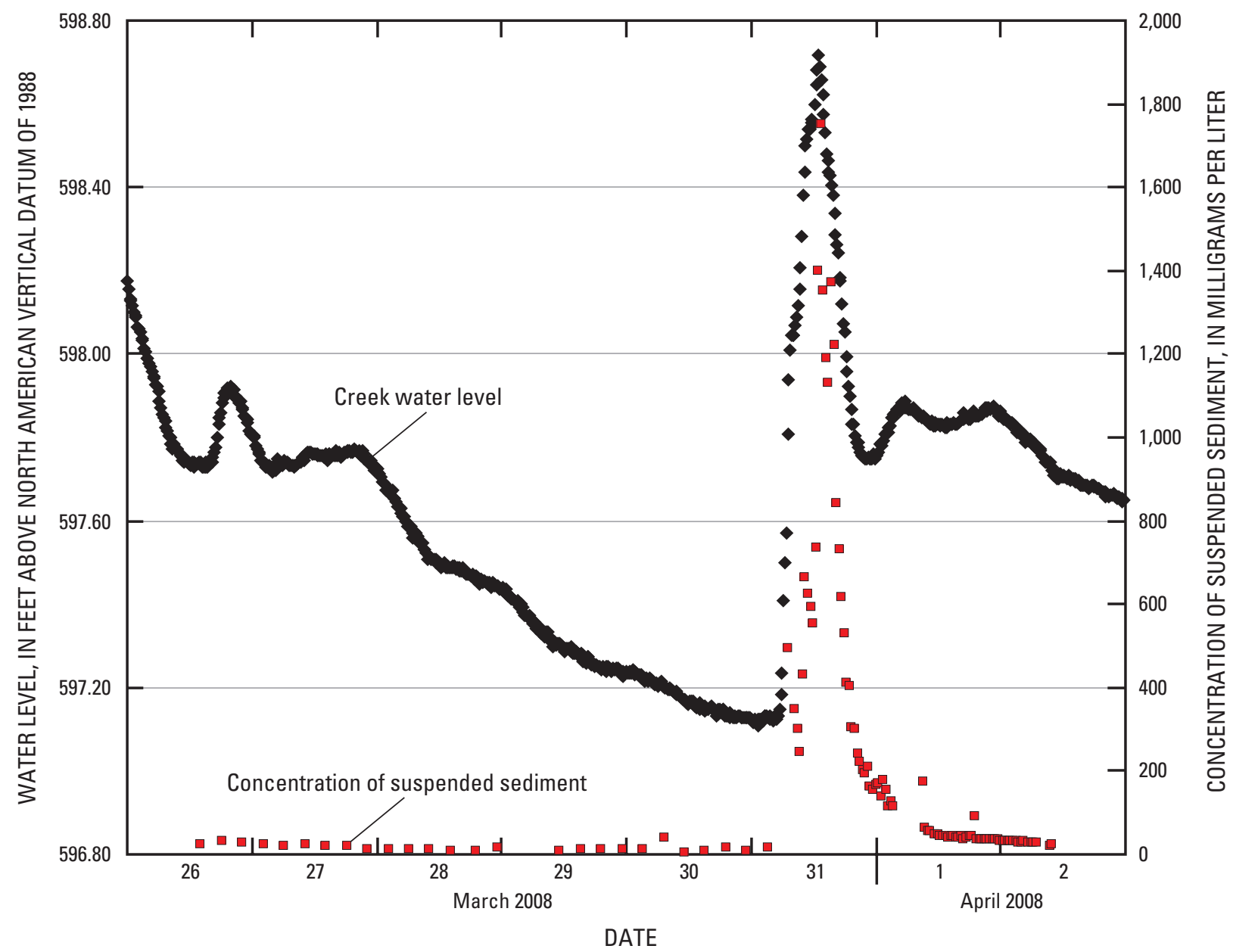

Figure 23. Water-level elevation and concentration of suspended sediment in Dead Dog Creek at gage DD1, Spring Bluff Nature Preserve, Winthrop Harbor, Illinois, March 26-April 2, 2008.

Suspended-sediment concentrations in samples collected at gages $\mathrm{W} 1, \mathrm{~W} 2, \mathrm{~W} 3$, and DD2 at the SBNP during March 31-April 2, 2008, indicate that sediment concentrations in the ditches and wetlands can be more than two orders of magnitude less than the highest concentrations entering the SBNP at gage DD1 (fig. 24). Although interpretation is limited by a lack of intensive sampling at several gages, the peak of the sediment pulse appears to move from gage DD1 (peak about 1330 hours on March 31) to W3 (about 1530 hours on March 31), then to gages W1 and DD2 (about 0930 hours on April 1) and W2 (peak at end of sampling at 1115 hours on April 2). Suspended sediment concentrations showed no clear increase at gage DD3, located near the outlet to Lake Michigan at the NUIBSP (fig. 24). Patterns and timing of the peaks in the trends in sediment concentrations were consistent with the patterns and timing of the water-level response to the June 8 rain event (fig. 15). Maximum suspended-sediment concentrations detected at the points of discharge to Lake
Michigan (gages W2 and DD3) were more than an order of magnitude lower than that at gage DD1, indicating that during storm events the ditches and wetlands function as sediment traps, removing much of the sediment from the water before it discharges to Lake Michigan.

Similarly, intensive sample collection on Bull Creek at gage DR1 during and after precipitation on August 23 and October 15-16, 2007, and April 10-13, 2008, also indicates that large changes in suspended-sediment concentrations occurred over a period of hours during and after the storms. Because water-level data were not continuously measured at gage DR1, changes in suspended-sediment concentration at gage DR1 cannot be related to gage height. However, if it is assumed that water levels at gages DD1 and DR1 follow similar trends, changes in suspended-sediment concentration at Bull Creek also are directly related to the change in stream elevation (and discharge) (fig. 25). 

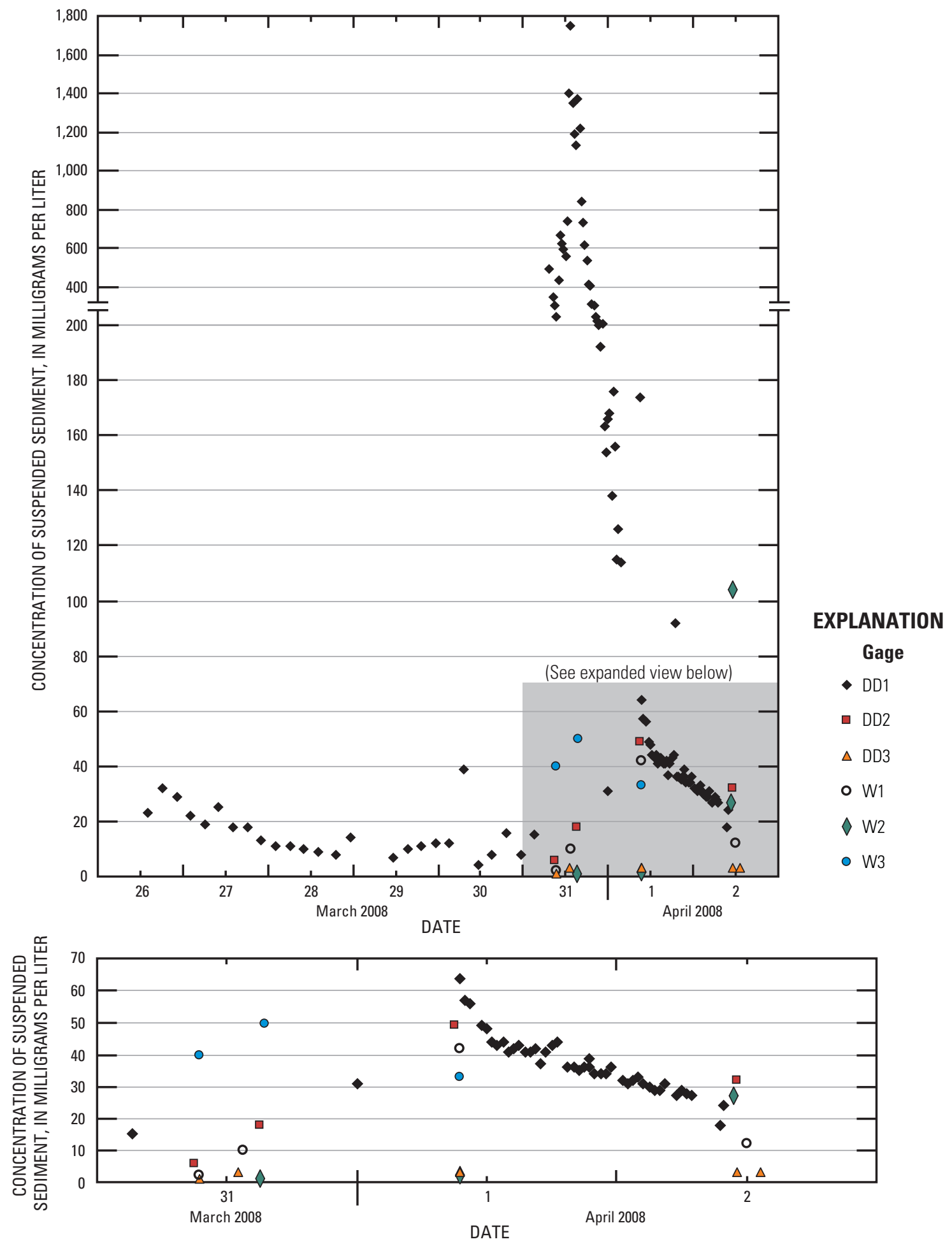

Figure 24. Concentration of suspended sediment in the Spring Bluff Nature Preserve, Northern Unit Illinois Beach State Park, and Chiwaukee Prairie State Natural Area, near Winthrop Harbor and Waukegan, Illinois, March 26-April 2, 2008. (Note variable scale in top graph.) 


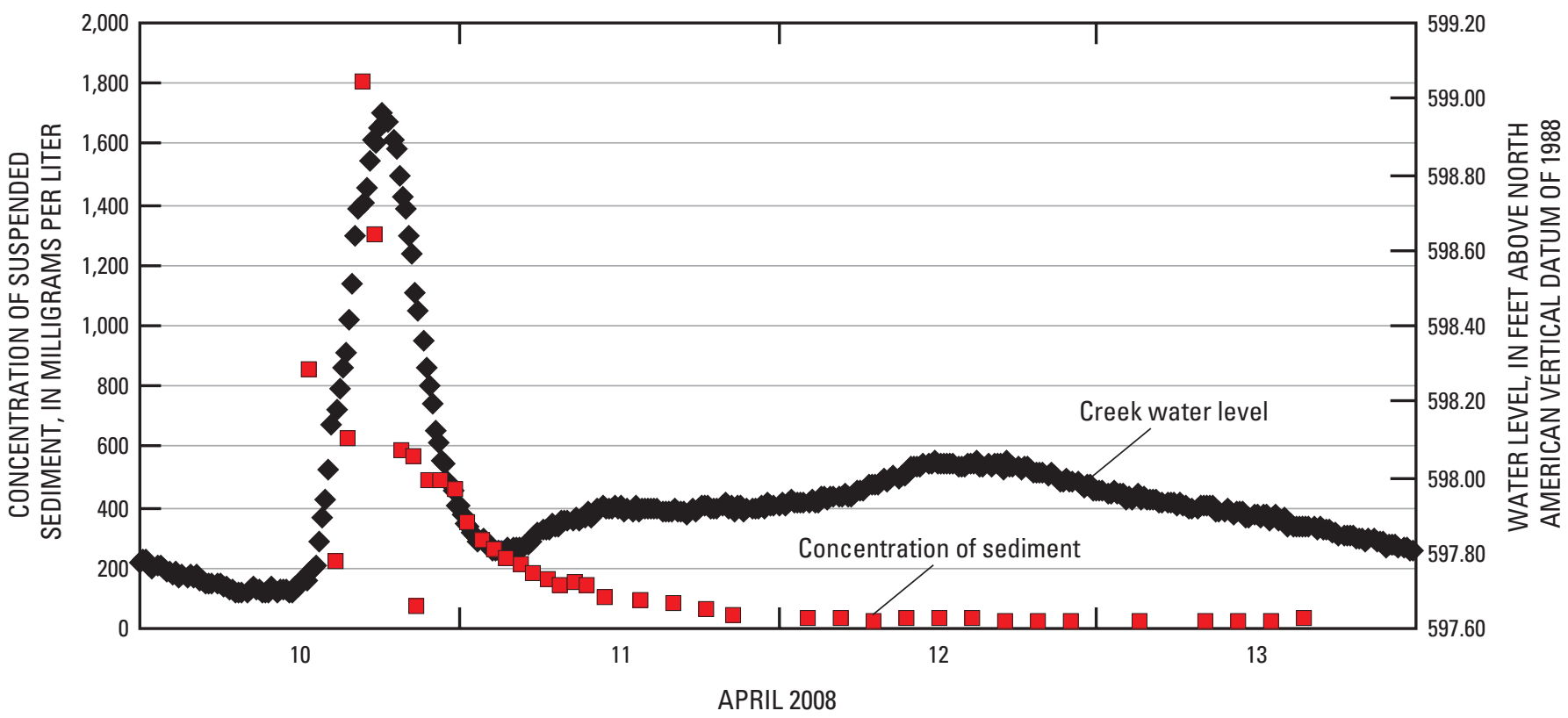

Figure 25. Concentration of suspended sediment in Bull Creek at gage DR1 and water level of Dead Dog Creek at gage DD1, near Winthrop Harbor and Waukegan, Illinois, April 10-13, 2008.

Suspended-sediment concentrations in samples from the wetland areas at the SUIBSP at gages DR2 and DR3 during the precipitation event of April 10-13, 2008, indicate that sediment concentrations in the wetlands were substantially less $(5$ to $54 \mathrm{mg} / \mathrm{L})$ than those in samples collected from the stream entering the wetlands at gage DR1 (maximum concentration $1,800 \mathrm{mg} / \mathrm{L}$ ). Concentrations at gage DR2 and DR3 are similar. These patterns are consistent with patterns in sediment concentration collected at the periodic sampling events. These patterns indicate that the wetlands, and especially the manmade ponds upstream from gage DR2, trap sediment entering the SUIBSP.

\section{Apparent Attenuation of Suspended Sediment, Chloride, Dissolved Phosphorous, and Nitrate Within the Wetland Complex}

Surface-water-quality data obtained during the period of sample collection indicate that urban and agricultural runoff affects water quality entering the wetland complex. It is probable, therefore, that the surface water entering, and within, the wetland complex has higher concentrations of numerous chemical constitutes, including chloride, nitrate, and possibly phosphorous and suspended sediment, than were present during presettlement conditions.

The concentration of constituents entering the wetland complex appear to be affected by the area and density of urban and agricultural land use within the watershed. The unnamed stream monitored at gage DD4 drains a small watershed with about 72 percent urban land use. This watershed has high concentrations of chloride (relative to gages DD1 and DR1) but has low concentrations of dissolved nitrate, dissolved phosphorous, and suspended sediment. Bull Creek and Dead Dog Creek drain larger watersheds with low to moderate percentages of agricultural land use ( 8 and 43 percent, respectively) and urban land use (50 and 26 percent, respectively). These watersheds have high (and often similar) concentrations of nitrate, dissolved phosphorous, and suspended sediment (during flood events), as well as moderate concentrations of chloride.

Within the various subunits of the wetland complex, specific conductance values and concentrations of chloride, nitrate, and suspended sediment — and dissolved phosphorous in some areas - decreased by a combination of chemical, biologic, and hydraulic processes occurring in the wetland complex. As a consequence, the concentrations of these constituents in water exiting the wetland complex and entering Lake Michigan, with the exception of suspended sediment and phosphorous in the northern part of the study area during some of the period of investigation, were lower than the respective concentrations entering the wetland complex. The degree of attenuation within the various subunits was consistently highest in the SUIBSP, the largest of the wetlands with potentially the longest residence time for water. The degree of attenuation is smallest in the NUIBSP, the driest part of the study area, where the degree of hydrologic alteration to the wetland appears to be moderate to large owing to the effects of the roads, ditches, and culverts in this area. Because the ditches facilitate the movement of water from the NUIBSP to the lake, water entering the NUIBSP has relatively little hydrologic interaction with the wetlands. When water can flow through 
the culvert at gage DD3, it is likely that the residence time of water in the NUIBSP is shorter than in the other parts of the study area. Moderate chemical attenuation occurred in the SBNP and CPSNA (relative to the NUIBSP and SUIBSP). The SBNP part of the wetland complex also has experienced substantial hydrologic alteration, partly because of these alterations water entering the SBNP and CPSNA has substantial residence time and hydrologic interaction with the wetlands before exiting to Lake Michigan. All preserves except the NUIBSP have substantial areas of standing water through which water entering the coastal complex must flow before discharging to Lake Michigan. These wet areas likely account for the larger improvements in water quality because they are the locations where many of the processes that improve water quality occur, such as sediment deposition, dilution, biological and chemical uptake, and precipitation onto organic matter.

\section{Relation of Hydrology and Water Quality to Invasive Species}

The vegetation changes observed within the wetland complex probably have multiple causes. The most apparent causes are hydrologic, but chemical effects also are evident. Statistical analyses indicate a strong positive correlation between Typha spp. importance (which is correlated with its abundance) and all indicators of wetness: mean depth to water $\left(R^{2}=-0.68\right)$, growing season mean depth to water $\left(R^{2}=-0.68\right)$, inundation duration $\left(\mathrm{R}^{2}=0.67\right)$, and growing season inundation duration $\left(\mathrm{R}^{2}=0.71\right)$ (table 13). These results indicate that Typha spp., the dominant herbaceous invasive species in many of the wetlands in the SBNP, is primarily impacting the wettest areas and that any anthropogenically induced increase in the hydroperiod in parts of the wetlands would increase the expansion of invasive species. Additionally, these statistical analyses show a strong relation between observed vegetative wetness and all measures of hydrology, presenting consistent characteristics for monitored sites. Analyses also show that Typha spp. abundances are not correlated with land-surface elevations $\left(R^{2}=-0.30\right)$, indicating the invasive impacts are not elevation controlled. The mean coefficient of conservatism did not correlate significantly with hydrologic wetness indicators (for example, $\mathrm{R}^{2}=0.14$ with mean depth to water). This result likely reflects the consistently high quality of vegetation in the preserves, with even impacted areas still having enough native species to retain high mean values for the coefficient of conservatism. Native species richness indices were significantly correlated with decreased wetness (for example, $\mathrm{R}^{2}=0.71$ with mean depth to water), but this finding could result from the fact that even pristine wet communities usually have less diverse plant assemblages than their drier counterparts. No significant correlations were observed with Phragmites australis (absolute value of all $\mathrm{R}^{2}$ values were less than 0.40 ), perhaps because of the small number of samples that contained the species.
These analyses are consistent with the data collected at the quadrats near the monitoring wells (table 10), which show Typha spp. in substantial amounts only in emergent marsh communities, where there is long-term standing water and average water levels that are near or above land surface. Typha spp. importance values appear to be less than 2 until the total days of inundation approach 200 (table 10; fig. 26), indicating that long-term inundation is required for Typha spp. dominance of the ecological community. Typha spp. importance values also are less than 2 until the average water level at a given location is at or above land surface (table 10; fig. 27), which also indicates that long-term inundation is required for Typha spp. dominance. Finally, data from the quadrats indicate that the species richness index increases as the depth to water increases and that emergent marshes are far less diverse than other wetland types (table 10; fig. 28) although, as noted earlier, some reduction in richness is expected even in pristine wet communities as compared to their drier counterparts.

Given that Typha spp. have not invaded all emergent marshes at the study area and that no significant differences in hydroperiod were found between emergent marshes measured in this study that contain Typha spp. and those that do not, other factors may be important to the spread of Typha spp., such as the total concentration of dissolved constituents in the water (indicated by values of specific conductance) and the concentration of nutrients. The only instrumented emergent marsh area not invaded by Typha spp. had a low specific conductance value in surface water (fig. 29) and was distant from surface-water inputs, possibly indicating a smaller effect from agricultural and urban runoff.

Specific conductance was highly correlated to the relative importance of Typha spp. $\left(\mathrm{R}^{2}=0.98\right)$ at the four locations where specific conductance was continuously monitored in emergent marshes in SBNP (fig. 14; table 13), indicating that there is an association between those areas affected by highconductivity runoff and the abundance of Typha spp. No correlations were evident for Phragmites australis, perhaps owing to the small number of individuals in the samples. The effects of other potential factors, such as nitrate concentrations, could not be determined because they were not measured in many of the wetland areas where vegetation parameters were measured.

Given that both water depth and specific conductance were highly correlated with the occurrence of Typha spp., it may not be possible to separate the effects of each. These factors co-vary because altered stream inputs produce more water of higher conductivity in the wetlands. Streams draining agricultural and urban areas generally have greater streamflow than in the presettlement condition (Booth and Jackson, 1997; Konrad and others, 2005; Konrad and Booth, 2005). They also generally have higher loads of chloride, nitrate, dissolved and suspended solids, and other constituents (Hamilton and others, 2001). Given the observations and data showing sedimentladen runoff water that enters and flows deeply into the preserves (for example, at W1 and W2 at SBNP), sediment-laden runoff could contribute to deleterious effects. 
Table 13. Pearson correlations and two-tailed p-values for selected parameters in the vicinity of the Spring Bluff Nature Preserve, Winthrop Harbor, Illinois, July 24, 2007July 7, 2008.

[DTW, depth to water; Sig., significance; corr., correlation; To normalize the data and obtain homogenous variances, all data sets were log-transformed before statistical analyses were performed. To avoid the creation of missing data values during transformations, data sets were uniformly adjusted so that all data had values of one or greater. Correlations were calculated from data at 22 locations, except for specific conductance, which was calculated based on data at 4 locations with water-quality dataloggers (wells 1, 7, 12, and 18)]

\begin{tabular}{|c|c|c|c|c|c|c|c|c|c|c|c|}
\hline & & $\begin{array}{c}\text { Growing- } \\
\text { season } \\
\text { mean } \\
\text { DTW }\end{array}$ & $\begin{array}{l}\text { Inundation } \\
\text { duration }\end{array}$ & $\begin{array}{l}\text { Growing- } \\
\text { season } \\
\text { inundation } \\
\text { duration }\end{array}$ & $\begin{array}{l}\text { Land- } \\
\text { surface } \\
\text { elevation }\end{array}$ & $\begin{array}{c}\text { Mean } \\
\text { specific } \\
\text { conductance }\end{array}$ & $\begin{array}{c}\text { Typha } \\
\text { relative } \\
\text { importance } \\
\text { value }\end{array}$ & $\begin{array}{l}\text { Phragmites } \\
\text { relative } \\
\text { importance } \\
\text { value }\end{array}$ & $\begin{array}{c}\text { Mean } \\
\text { vegetative } \\
\text { wetness }\end{array}$ & $\begin{array}{c}\text { Native } \\
\text { mean } \\
\text { coefficient } \\
\text { of } \\
\text { conservatism }\end{array}$ & $\begin{array}{c}\text { Native } \\
\text { species } \\
\text { richness } \\
\text { index }^{\mathrm{c}}\end{array}$ \\
\hline \multirow[t]{2}{*}{ Mean DTW } & Pearson corr. & ${ }^{\mathrm{b}} 0.98$ & $\mathrm{~b}^{\mathrm{b}}-0.80$ & ${ }^{\mathrm{b}}-0.79$ & ${ }^{\mathrm{a}} 0.45$ & -0.33 & ${ }^{b}-0.68$ & -0.13 & ${ }^{\mathrm{b}} 0.85$ & 0.14 & ${ }^{\mathrm{b}} 0.71$ \\
\hline & Sig. (two-tailed) & 0 & 0 & 0 & .04 & .67 & 0 & .57 & 0 & .53 & 0 \\
\hline \multirow{2}{*}{$\begin{array}{l}\text { Growing-season } \\
\text { mean DTW }\end{array}$} & Pearson corr. & & $\mathrm{b}_{-} .82$ & $\mathrm{~b}_{-} .81$ & ${ }^{\mathrm{b}} .55$ & -.31 & $b_{-} .68$ & -.09 & ${ }^{\mathrm{b}} .88$ & .20 & b.73 \\
\hline & Sig. (two-tailed) & & 0 & 0 & .01 & .69 & 0 & .68 & 0 & .37 & 0 \\
\hline \multirow[t]{2}{*}{ Inundation duration } & Pearson corr. & & & b. .97 & $b_{-} .60$ & .13 & ${ }^{\mathrm{b}} .67$ & .13 & $\mathrm{~b}_{-} .85$ & -.12 & $b_{-} .65$ \\
\hline & Sig. (two-tailed) & & & 0 & 0 & .87 & 0 & .56 & 0 & .60 & 0 \\
\hline \multirow{2}{*}{$\begin{array}{l}\text { Growing-season } \\
\text { inundation duration }\end{array}$} & Pearson corr. & & & & $\mathrm{b}_{-} .55$ & .10 & b. 71 & .15 & $\mathrm{~b}_{-} .84$ & -.16 & $\mathrm{~b}_{-} .70$ \\
\hline & Sig. (two-tailed) & & & & .01 & .90 & 0 & .51 & 0 & .47 & 0 \\
\hline \multirow[t]{2}{*}{ Land-surface elevation } & Pearson corr. & & & & & .26 & -.30 & .28 & ${ }^{\mathrm{b}} .62$ & -.04 & .28 \\
\hline & Sig. (two-tailed) & & & & & .74 & .17 & .21 & 0 & .85 & .21 \\
\hline \multirow{2}{*}{$\begin{array}{l}\text { Mean specific } \\
\text { conductance }\end{array}$} & Pearson corr. & & & & & & a .98 & .20 & .56 & -.23 & -.62 \\
\hline & Sig. (two-tailed) & & & & & & .02 & .80 & .44 & .77 & .38 \\
\hline \multirow{2}{*}{$\begin{array}{l}\text { Typha relative } \\
\text { importance value }\end{array}$} & Pearson corr. & & & & & & & .35 & $b_{-} .66$ & -.39 & $\mathrm{~b}_{-} .83$ \\
\hline & Sig. (two-tailed) & & & & & & & .11 & 0 & .07 & 0 \\
\hline \multirow{2}{*}{$\begin{array}{l}\text { Phragmites relative } \\
\text { importance value }\end{array}$} & Pearson corr. & & & & & & & & -.10 & -.07 & -.23 \\
\hline & Sig. (two-tailed) & & & & & & & & .65 & .76 & .31 \\
\hline \multirow{2}{*}{$\begin{array}{l}\text { Mean vegetative } \\
\text { wetness }\end{array}$} & Pearson corr. & & & & & & & & & .22 & b. .73 \\
\hline & Sig. (two-tailed) & & & & & & & & & .32 & 0 \\
\hline \multirow{2}{*}{$\begin{array}{l}\text { Native mean } \\
\text { coefficient of } \\
\text { conservatism }\end{array}$} & Pearson corr. & & & & & & & & & & ${ }^{\mathrm{b}} .63$ \\
\hline & Sig. (two-tailed) & & & & & & & & & & 0 \\
\hline
\end{tabular}

${ }^{a}$ Correlation is significant at the 0.05 level (two-tailed). Although this is a strong correlation, it is less significant than some other correlations because specific conductance data were collected at only four wells.

${ }^{\mathrm{b}}$ Correlations significant at the 0.01 level (two-tailed)

${ }^{\mathrm{c}}$ Native species richness index values will be naturally lower in wet environments, so correlations partly reflect this natural trend and are likely not as significant as indicated. 


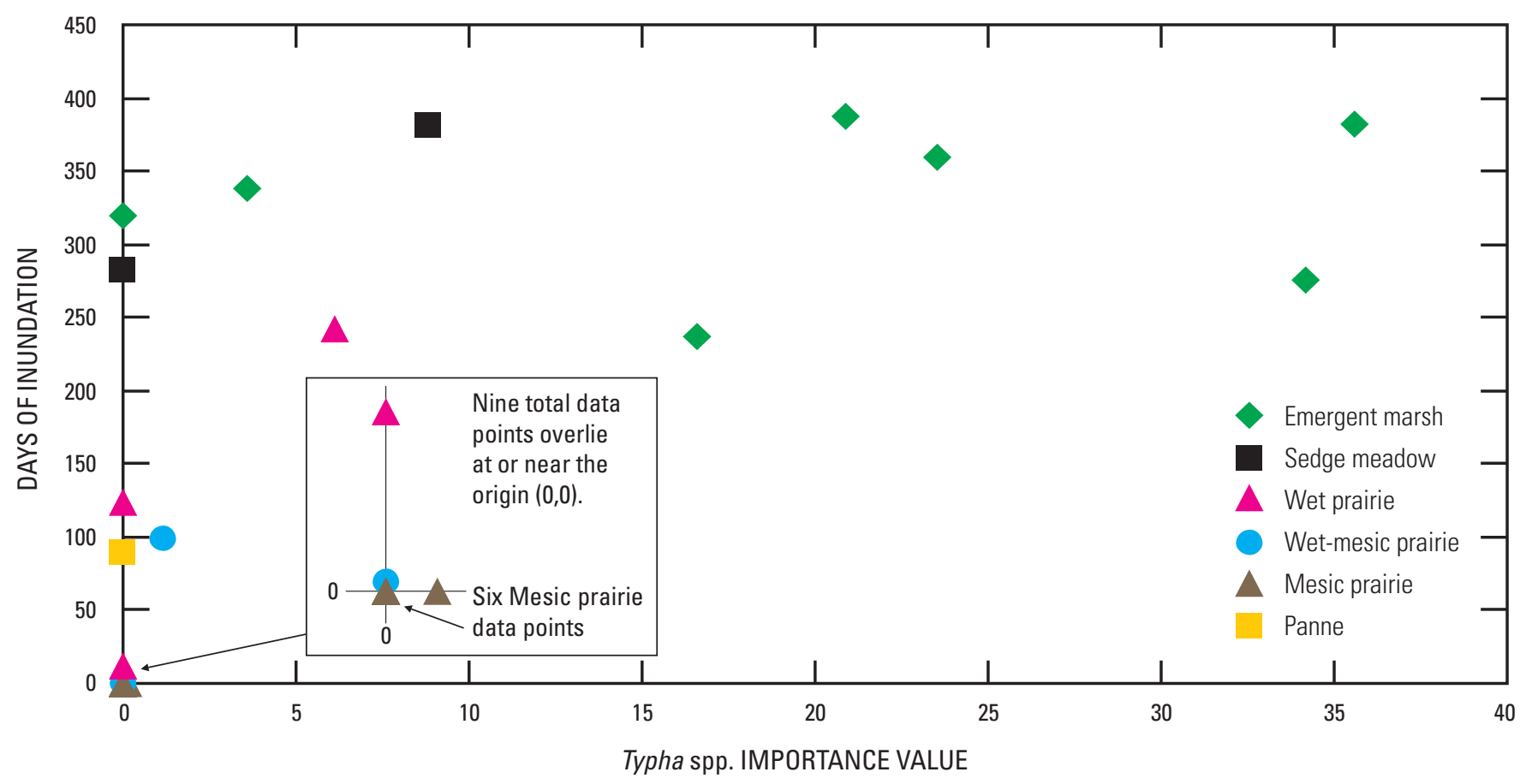

Figure 26. Relation of Typha spp. importance value to days of inundation at vegetation-monitoring points in the Spring Bluff Nature Preserve, Northern Unit Illinois Beach State Park, and Chiwaukee Prairie State Natural Area, near Winthrop Harbor and Waukegan, Illinois, July 24, 2007-August 27, 2008.

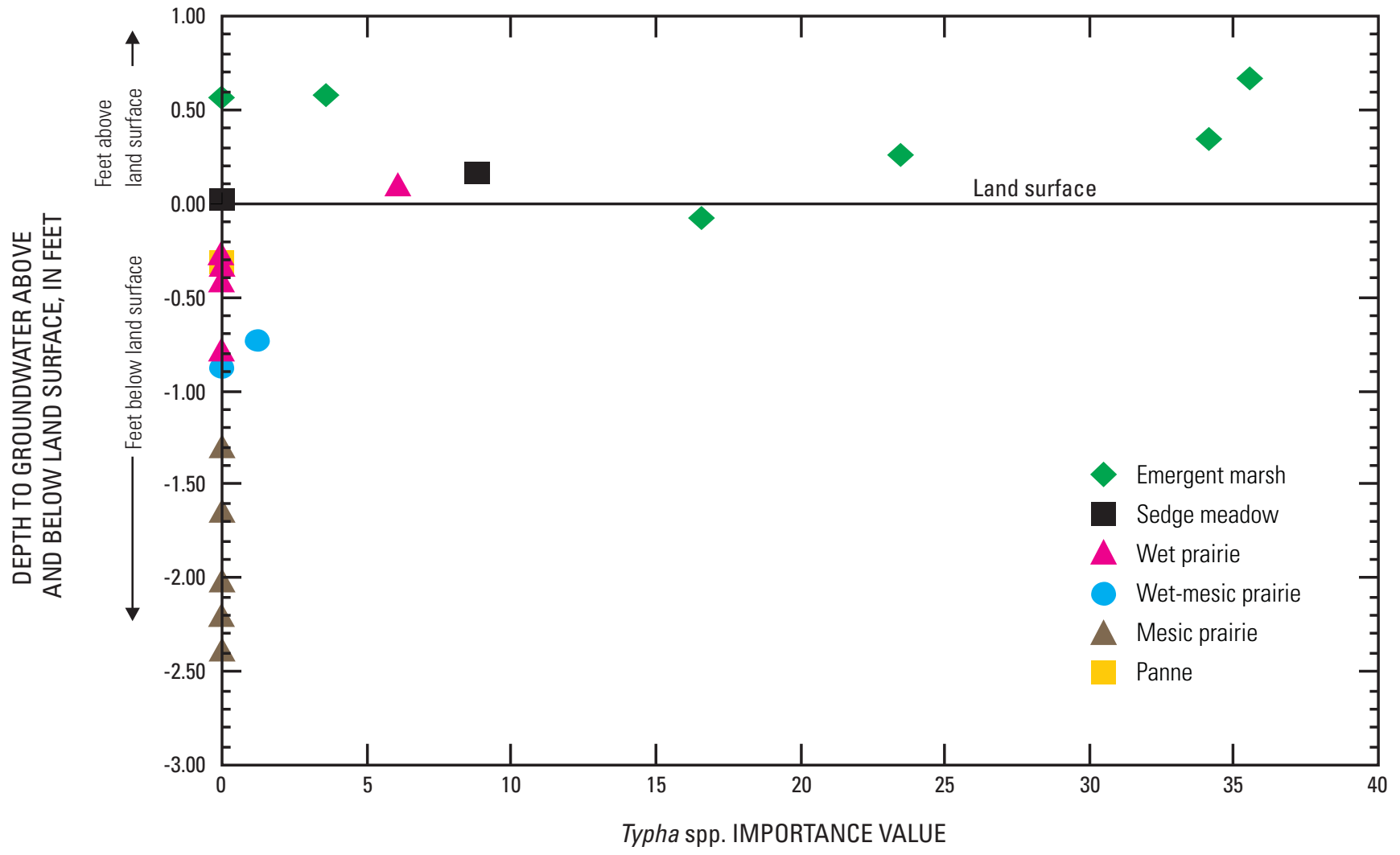

Figure 27. Relation of Typha spp. importance values to average depth to groundwater at vegetation-monitoring points in the vicinity of the Spring Bluff Nature Preserve, Northern Unit Illinois Beach State Park, and Chiwaukee Prairie State Natural Area, near Winthrop Harbor and Waukegan, Illinois, July 24-August 27, 2008. 


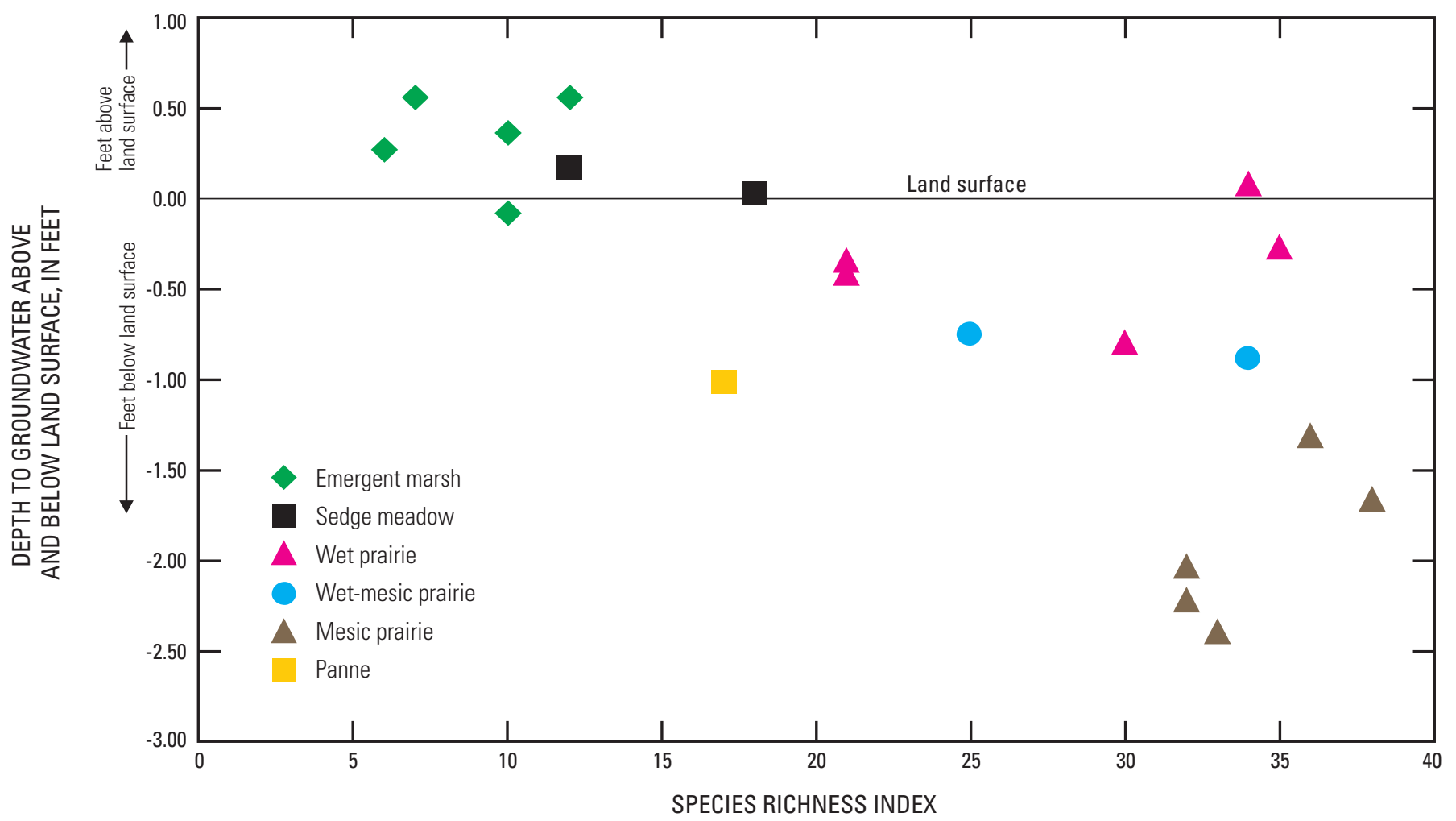

Figure 28. Relation of species richness index (SRI) values to average depth to groundwater at monitoring-well locations in the Spring Bluff Nature Preserve, Northern Unit Illinois Beach State Park, and Chiwaukee Prairie State Natural Area, near Winthrop Harbor and Waukegan, Illinois.

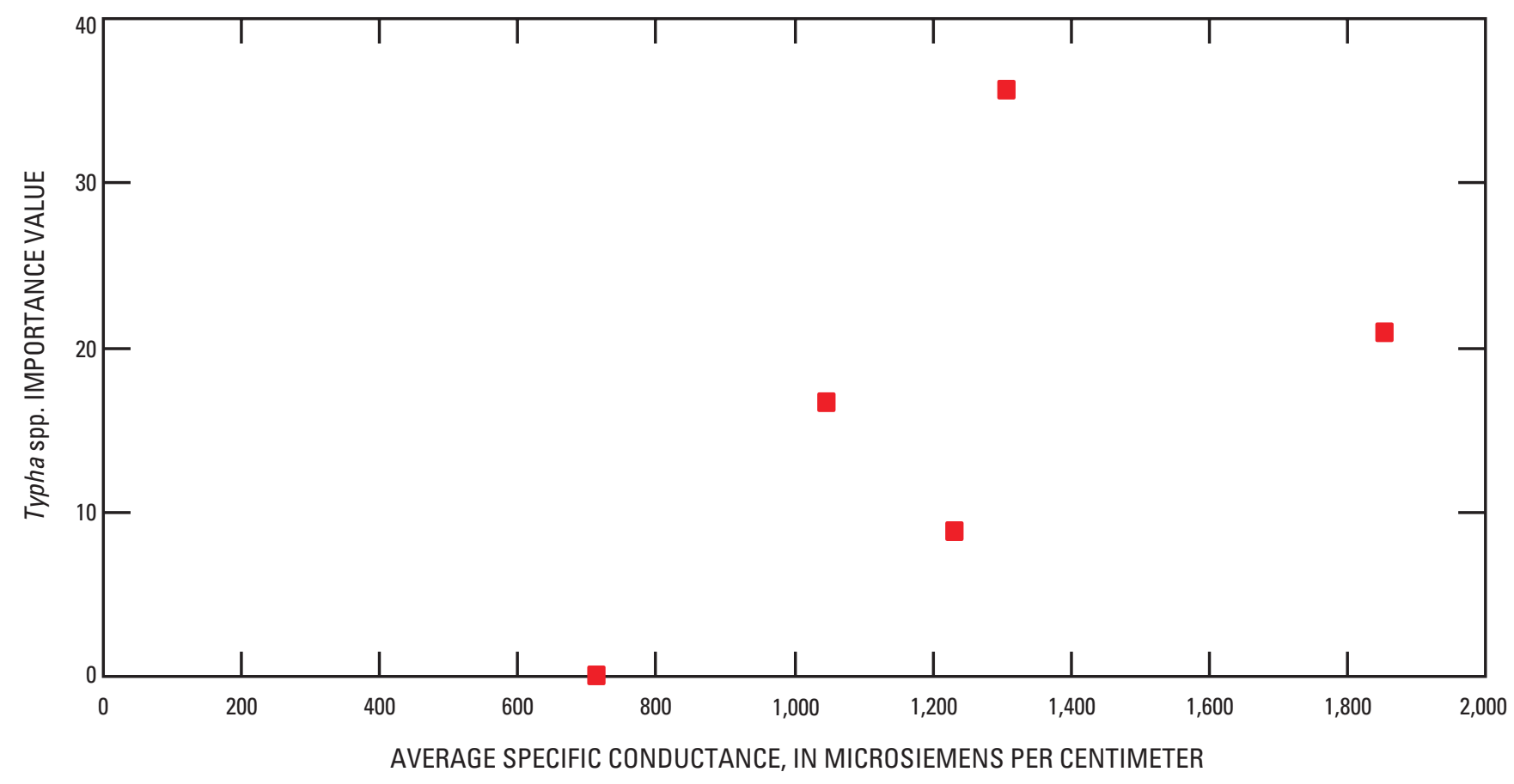

Figure 29. Relation of Typha spp. importance values to specific conductance of surface water in the Spring Bluff Nature Preserve, Northern Unit Illinois Beach State Park, and Chiwaukee Prairie State Natural Area, near Winthrop Harbor and Waukegan, Illinois. 
In addition to agricultural and urban runoff, other hydrologic alterations such as berms, roadways, and blocked culverts will extend and deepen inundation, and by themselves may exacerbate the spread and abundance of Typha spp. The hydrology of the only monitored emergent marsh (well 18) that lacks Typha spp. does not differ substantially from that of other emergent marshes in SBNP and CPSNA. However, it has substantially lower specific conductance. It is possible that the hydrology near well 18 already has been altered, thus making the area conducive for Typha spp. invasion; it may simply require time for colonization of all available habitat. Typha spp. has been observed near this location southward along the same interdunal swale wetland, suggesting that colonization is imminent. Although the controlling aspects of specific conductance cannot be ruled out in this limited study, other ecological factors such as seed source, disturbance, and land management also may play a role in Typha spp. spread and occurrence.

The study area likely receives much more runoff now than during presettlement times because of expanded agricultural and urban land use. Given that some drainageways were observed to be restricted by blocked culverts, roadways, elevated rains, and earthwork, it is likely that the emergent marsh plant community has been expanding at the expense of sedge meadows and other wetland communities that formerly occurred at the edges of the fringes of the emergent marsh communities. Indeed, dead sedge tussocks have been observed in areas now dominated by deep water and Typha spp. in the SBNP. These changes are evidence of an increase in hydroperiod and an alteration to the wetland plant communities. Memories of long-time residents who recall a general lack of standing water throughout the preserve constitute anecdotal evidence suggesting an expansion of inundation. Although Typha spp. have been present since the early 1900s, the observed increase in Typha spp. is likely associated with the observed growth of emergent marsh habitat. Decreased water quality of runoff also likely is exacerbating the spread of Typha spp. and possibly other aggressive plant species, and this is likely happening in concert with the extended inundation. Given that the factors are intertwined, it is not possible with the current data to separate them completely for the purposes of resource managers in determining restoration activities. However, additional collection of water-quality and plant-community data at more locations may help refine knowledge of the specific impacts of each factor.

Because the spread of invasive species in the SBNP appears to be affected by the depth of water, reducing the water depth with the SBNP wetland may help mitigate these effects. Limiting wetness in the affected areas would likely require human-induced alterations to the current flow pattern and water-levels via improved culvert maintenance, new culverts, and drains. Many of the protected plant communities in the area depend on wet conditions; therefore, such changes may have unintended consequences, some of them potentially adverse. In order for resource managers to make definitive restoration plans and targets, it may be of interest to pursue additional quantitative information regarding evidence that the study area is currently wetter than it has been in the historic past. Given the lack of quantitative assessments of past conditions, the only evidence of changes may be contained in the organic soils of the sites. If plant communities have changed in the recent past, evidence may exist in the form of plant macrofossils, which may be preserved in the continually saturated organic soils. If such evidence is found, it may be possible to establish target hydroperiods for lowered water levels. Additional mapping of dead sedge tussocks and similar features also may provide elevation information to assist in determining optimal water levels. Changing the quality and quantity of runoff entering the preserves is another potential restoration action that also may have unintended consequences. Potential management changes that might be investigated include rerouting of runoff through the preserves, installation of storage structures upstream from the preserves, and various watershed management activities. Many of these possible management alternatives would be expected to affect water quality and quantity, which would address both potential causes of vegetation alteration.

Because there is an incomplete understanding of the site history, continued monitoring in the area may be beneficial. A quantitative record of biological and hydrological changes may be important in determining future effects of various activities. Additionally, continued monitoring of hydrology and expanded monitoring of water quality may benefit land stewards, allowing them to make resource-management decisions with a more complete knowledge of site history. If further hydrologic alterations are deemed appropriate, the monitoring described in this report could provide baseline data for resource managers to establish appropriate water-level and water-quality objectives in this and similar wetland communities, and for future studies at these sites.

\section{Summary and Conclusions}

The U.S. Geological Survey, Illinois State Geological Survey and the Lake County Forest Preserve District conducted an investigation of the hydrology, water quality, and vegetation in the wetland complex in the Spring Bluff Nature Preserve, Chiwaukee Prairie State Natural Area, and Illinois Beach State Park (Northern and Southern Units) along the shore of Lake Michigan in northeastern Lake County, Ill., and adjacent areas of southern Wisconsin. This investigation was performed during May 2007-August 2008.

Anthropogenic activities have altered the hydrology and water quality of the wetland complex. Agricultural and increasingly urban land use in the watersheds likely has increased streamflow into the wetland complex relative to presettlement conditions. The natural flow system within the complex has been disrupted by the construction of culverts, roads, ditches, storm drains, and berms. The probable net effects of these alterations are that storage of water has increased in much of the SBNP and western part of the SUIBSP, the 
movement of surface water has decreased within and between the various subunits within the wetland complex (particularly the NUIBSP), the hydroperiod has increased in parts of the SBNP (particularly the eastern third), and the hydroperiod decreased in that part of the NUIBSP that was investigated and may have increased in the western part of the SUIBSP.

Surface-water runoff into the wetland complex likely contains higher concentrations of chloride, nitrate, phosphorous, and sediment relative to presettlement conditions. Concentrations of these constituents are affected by the percentage of agricultural and urban land use within the watersheds entering the wetland complex. Biological and hydraulic processes in the wetlands reduce the concentration of nitrate and chloride in the water exiting the coastal wetland complex into Lake Michigan by as much as 85 and 75 percent, respectively. Dissolved phosphorous concentrations decreased across the SUIBSP by about 60 percent, but spatial patterns in phosphorous concentrations in the northern part of the study area are not clear. The ponds and wetlands appear to be trapping sediment in the water moving through the wetland complex, particularly during storm events. These reductions are the result of various processes that occur in the coastal complex that differ by type of contaminant. These processes include dilution, transformations by microbes, uptake by plants, adsorption onto sediments, and deposition.

Groundwater levels associated with the various plant communities in SBNP, CPSNA, NUIBSP, and SUIBSP show that hydroperiods in each community type were similar but that average hydroperiods were distinct for each community type. Emergent marsh wetlands often had more than 1 foot of standing water with little or no time when water levels were below land surface. Sedge meadows were the second wettest community, with shallow standing water for months in winter to early summer and water levels slightly below land surface for the remainder of the year, allowing propagation of sedge species. Wet prairies were slightly less wet, with highest water levels at or slightly above land surface for a few weeks in the late winter to late spring, with levels falling off dramatically in the summer. Water levels in wet-mesic and mesic prairies generally did not rise above land surface or did so only temporarily, and were well below land surface for much of the year.

Hydroperiods of emergent marsh communities containing Typha spp. were similar to the hydroperiod of the emergent marsh that lacked Typha spp., most likely indicating that the hydroperiods have already been altered, but there may be a time lag between the hydrologic alteration and the colonization by Typha spp. of all available habitats. Therefore, areas of emergent marsh in the coastal complex where invasive species have not been observed, such as the monitored part of the CPSNA, may be areas that are farther from the Typha spp. point of origin that will eventually be colonized. High concentrations of dissolved solids in the water also may be promoting the spread of invasive species, especially because they derive from the same factors that altered the hydrology. However, Typha spp. and other invasive species will likely spread even to emergent wetland areas of lower specific conductance. In addition, other factors not addressed in this investigation may influence the distribution of Typha spp., such as land management, disturbance history, and watershed-level alterations.

Groundwater and surface-water levels in wetlands were strongly associated with plant-species diversity and occurrence in the study area. Anecdotal evidence from long-term residents and land managers, as well as the presence of submerged sedge tussocks, indicate that water levels in the SBNP have increased through time. Although this study does not definitively demonstrate whether such changes have taken place, it is a supportable assumption. Analysis of the data collected during this investigation indicates that the construction of roadbeds, berms, storm drains, and other structures, along with potential increases in the volume and rate of runoff, likely have increased the volume of water entering the SBNP and decreased the rate at which water exits the SBNP relative to natural conditions. Culverts, ditches, and drains were installed to help drain the site, but at least some of these features are no longer functional or have clogged. The resultant ponding likely has expanded the extent of emergent marsh communities, and may have allowed Typha spp. to expand at the expense of other types of wetland plants. Given that the specific conductance of surface waters is also correlated with Typha spp. abundance and that runoff quality was found to contain indicators of the agricultural and urban land use in the watershed, both the quality and quantity of runoff are a prime concern for the long-term viability of the natural plant communities in the study area. Sampling of a larger number of sites and for a larger suite of water-quality constituents would be more definitive when comparing the potential effects of increased inundation from onsite hydrologic alterations relative to the effects of the water quality of the runoff entering the site.

\section{References Cited}

Allan, J.D., 1995, Stream ecology-Structure and function of
running waters: London, Chapman and Hall, 388 p.

Boers, A.M., and Zedler, J.B., 2008, Stabilized water levels and Typha invasiveness: Wetlands, v. 28, no. 3, p. 676-685.

Booth, D.B., and Jackson, C.R., 1997, Urbanization of aquatic systems - Degradation thresholds, stormwater detection, and the limits of mitigation: Journal of the American Water Resources Association, v. 33, no. 5, p. 1077-1090.

Bowles, Marlin, and Jones, Michael, 2007, The prairiewetland vegetation continuum in the Chicago Region of Northeastern Illinois: Ecological Restoration, v. 25, no. 1, p. $29-42$.

Boyd, C.E., 2000, Water quality, an introduction: Boston, Kluwer Academic Publishers, 330 p. 
Chicago Wilderness Society, 1999, Biodiversity recovery plan: Chicago, Ill., 195 p.

Chrzastowski, M.J., 2001, Geology of the Zion Beach-Ridge Plain, a Holocene, migratory, coastal-sedimentary systemField trip guidebook, Society of Economic and Petrographic Mineralogists/Society for Sedimentary Geology Great Lakes Section Annual Field Conference, September 14-16, 2001, Zion, Illinois: Champaign, Ill., 60 p.

Coon, W.F., Bernard, J.M., and Seischab, F.K., 2000, Effects of a cattail wetland on water quality of Irondequoit Creek near Rochester, New York: U.S. Geological Survey WaterResources Investigations Report 00-4032, 74 p.

Feth, J.H., 1981, Chloride in natural continental water-A review: U.S. Geological Survey Water-Supply Paper 2176, $30 \mathrm{p}$.

Fishman, M.J., and Friedman, L.C., 1989, Methods for determination of inorganic substances in water and fluvial sediments ( $3 \mathrm{~d}$ ed.): U.S. Geological Survey Techniques of Water-Resources Investigations, book 5, Laboratory Analysis, chap. A1, p. 459-460.

Gates, F.C., 1912, The vegetation of the beach area in northeastern Illinois and southeastern Wisconsin: Bulletin of the Illinois State Laboratory Natural History, v. 9, p. 255-372.

Geis, J.W., 1985, Environmental influences on the distribution and composition of wetlands in the Great Lakes Basin, in Prince, H.H., and D'Itri, F.M., eds., Coastal wetlands: Chelsea, Mich., Lewis Publishers, p. 15-31.

Great Lakes Water Level for Lake Michigan/Huron, http://www.in.gov/dnr_old/water/lake_michigan/coastal/ pdf/03WaterLevelTable1981-2008LakeMichigan.pdf, accessed May 7, 2009.

Hamilton, P.A., Miller, T.L., and Myers, D.N., 2001, Water quality in the Nation's streams and aquifers-Overview of selected findings, 1991-2001: U.S. Geological Survey Circular 1265, 20 p.

Heath, R.T., 1992, Nutrient dynamics in Great Lakes coastal wetlands-Future directions: Journal of Great Lakes Research, v. 18, no. 4, p. 590-602.

Hem, J.D., 1992, Study and interpretation of chemical characteristics of natural water (3d ed.): U.S. Geological Survey Water-Supply Paper 2254, 263 p.

Hensel, B.R., 1992, Natural recharge of groundwater in Illinois: Champaign, Ill., Illinois State Geological Survey Environmental Geology 143, 33 p.

Illinois Pollution Control Board, 1978, Title 35, subtitle C, part 302: Springfield, Ill., Illinois Administrative Code, $177 \mathrm{p}$.
Indiana Department of Natural Resources, 2008, Great Lakes water level for Lake Michigan/Huron, accessed May 7 , 2009, at http://www.in.gov/dnr_old/water/lake_michigan/ coastal/pdf/03WaterLevelTable1981-2008LakeMichigan.pdf

Kercher, S.M., and Zedler, J.B., 2004a, Flood tolerance in wetland angiosperms - A comparison of invasive and noninvasive species: Aquatic Biology, v. 80, no. 2, p. 89-102.

Kercher, S.M., and Zedler, J.B., 2004b, Multiple disturbances accelerate invasion of reed canary grass (Phalaris arundinacea L.) in a mesocosm study: Oecologia, v. 138, no. 3, p. $455-464$.

Kludze, H.K., and DeLaune, R.D., 1996, Soil redox intensity effects on oxygen exchange and growth of cattail and sawgrass: Soil Science Society of America Journal, v. 60, no. 2, p. 616-621.

Konrad, C.P., 2003, Effects of urban development on floods: U.S. Geological Survey Fact Sheet FS-076-03, 4 p.

Konrad, C.P., and Booth, D.B., 2005, Hydrologic changes in urban streams and their ecological significance, in Brown, L.R., Gray, R.H., Hughes, R.M., and Meador, M.R., eds., Effects of urbanization on stream ecosystems: Bethesda, Md., American Fisheries Society Symposium 47, p. $157-$ 177.

Konrad, C.P., Booth D.B., and Burges, S.J., 2005, Effect of urban development in the Puget Lowland, Washington, on interannual streamflow patterns - Consequences for channel form and streambed disturbance: Water Resources Research, v. 41, no. 7, article W07009, 15 p.

Kubillus, S.L., 1994, Hydrology of Dead Dog creek, nearby wetlands, and their relationship to Lake Michigan: Chicago, Ill., Northeastern Illinois University, unpublished M.S. thesis, 295 p.

Lake County Stormwater Management Commission, 2008a, Kellogg Creek watershed plan: Libertyville, Ill., 247 p.

Lake County Stormwater Management Commission, 2008b, Dead River watershed plan: Libertyville, Ill., 235 p.

Lewis, Jack, 1996, Turbidity-controlled suspended sediment sampling for runoff-event load estimation: Water Resources Research, v. 32, no. 7, p. 2299-2310.

Li, Shuwen, Pezeshki, S.R., and Goodwin, Shirlean, 2004, Effects of soil moisture regimes on photosynthesis and growth in cattail (Typha latifolia): Acta Oecoligica, v. 25, no. 1-2, p. 17-22.

Marburger, Joy, Travis, Steven, Windels, Steve, 2005, Cattail sleuths use forensic science to better understand spread of an invasive species: Denver, Colo., National Park Service, Natural Resource Year in Review, D-1755/April 2006, p. 75,76 . 
Maynard, Laurie, and Wilcox, Douglas, 1997, Coastal wetlands-State of the Lakes Ecosystem Conference (SOLEC) 1996, background paper: Environment Canada and U.S. Environmental Protection Agency, EPA 905-R-97-015, $103 \mathrm{p}$.

McCullough, G.B., 1985, Wetland threats and losses in Lake St. Clair, in Prince, H.H., and D'Itri, F.M., eds., Coastal wetlands: Chelsea, Mich., Lewis Publishers, p. 201-208.

Midwestern Regional Climate Center, 2008, Midwestern Climate Information System: Champaign, Ill., Illinois State Water Survey, available online at http://MRCC.sws.uiuc.edu

Miner, J.J., and Simon, S.D., 1997, A simplified soil-zone monitoring well: Restoration and Management Notes, v. 15, no. 2 , p. $156-160$.

Mitsch, W.J., and Gosselink, J.G., 2007, Wetlands (4th ed.): New York, John Wiley and Sons, 920 p.

Mueller, D.K., and Helsel, D.R., 1996, Nutrients in the Nation's waters - Too much of a good thing?: U.S. Geological Survey Circular 1136, 24 p.

National Water and Climate Center, Natural Resources Conservation Service, 1995, WETS table documentation, available online at $h t t p: / / w w w . w c c . n r c s . u s d a . g o v / c l i m a t e /$ wets_doc.html

National Water and Climate Center, Natural Resources Conservation Service, 2008, Climate analysis for wetlands by county, available online at $h t t p: / / w w w . w c c . n r c s . u s d a . g o v /$ climate/wetlands.html

Panno, S.V., Nuzzo, V.A ., Cartwright, K., Hensel, B.R., and Krapac, I.G., 1999, Impact of urban development on the chemical composition of groundwater in a fen-wetland complex: Wetlands, v. 19, no. 1, p. 236-245.

Radtke, D.B., White, A.F., Davis, J.V., and Wilde, F.D., 1998, Dissolved oxygen, in Wilde, F.D., and Radtke, D.B., eds., 1998, Field measurements - National field manual for the collection of water-quality data: U.S. Geological Survey Techniques of Water-Resources Investigations, book 9 , chap. A6.2, 38 p.

Randall, J.M., 1996, Weed control for the preservation of biological diversity: Weed Technology, v. 10, no. 2, p. 370383.

Rantz, S.E., and others, 1982, Measurement and computation of streamflow-Volume 1. Measurement of stage and discharge: U.S. Geological Survey Water-Supply Paper 2175, $284 \mathrm{p}$.
Shreve, E.A., and Downs, A.C., 2005, Quality-assurance plan for the analysis of fluvial sediment by the U.S. Geological Survey Kentucky Water Science Center Sediment Laboratory: U.S. Geological Survey Open-File Report 2005-1230, $28 \mathrm{p}$.

Smith, G.S., 1967, Experimental and natural hybrids in North American Typha (Typhaceae): American Midland Naturalist, v. 78, no. 2, p. 257-287.

Spuhler, D.R., 1995, Low plant diversity found in communities dominated by reed canary grass (Phalaris arundinacea), in Hartnett, D.C., ed., Proceedings of the Fourteenth Annual North American Prairie Conference, Kansas State University, Manhattan, Kans., July 12-16, 1994: p. 43-47.

Stumm, Werner, and Morgan, J.J., 1981, Aquatic chemistry ( $2 \mathrm{~d}$ ed.): New York, Wiley, $780 \mathrm{p}$.

Sweeney, B.W., 1984, Factors influencing life-history patterns of aquatic insects, in Resh, V.H., and Rosenberg, D.M., eds., The ecology of aquatic insects: New York, Praeger Scientific, p. 56-100.

Swink, Floyd, and Wilhelm, Gerould, 1994, Plants of the Chicago region (4th ed.): Indianapolis, Ind., Indiana Academy of Science, $921 \mathrm{p}$.

Tarr, Matt, and Babbitt, K.J., 2006, The importance of hydroperiod in wetland assessment: Durham, N.H., University of New Hampshire Cooperative Extension, 23 p.

Thrush, S.F., Hewitt, J.E , Cummings, V.J., Ellis, J.I., Hatton, C., Lohrer, A., and Norkko, A., 2004, Muddy waters-Elevating sediment input to coastal and estuarine habitats: Frontiers in Ecology and the Environment, v. 2, no. 6, p. 299-306.

U.S. Army Corps of Engineers, Environmental Laboratory, 1987, Corps of Engineers Wetlands Delineation Manual: Vicksburg, Miss., Technical Report Y-87-1, 169 p.

U.S. Department of Agriculture, Forest Service, Southern Division, 1996, Southern Appalachian Man and the Biosphere (SAMAB) - The Southern Appalachian Assessment aquatics technical report (report 2 of 5): Atlanta, Ga., 166 p.

Visocky, A.P., 1976, A hydrologic study of Illinois beach state park: Illinois State Water Survey Contract Report 1-47-2684-370-00, 108 p.

Wagner, R.J., Mattraw, H.C., Ritz, G.F., and Smith, B.A., 2000, Guidelines and standard procedures for continuous water-quality monitors - Site selection, field operation, calibration, record computation, and reporting: U.S. Geological Survey Water-Resources Investigations Report 00-4252, $53 \mathrm{p}$. 
Webster, J.R., Wallace, J.B., and Benfield, E.F., 1995, Organic processes in streams of the eastern United States, in Cushing, C.E., Cummins, K.W., and Minshall, G.W., eds., River and stream ecosystems: Amsterdam, Elsevier, Ecosystems of the World 22, p. 117-187.

Werner, K.J., 2001, Stormwater sedimentation alters soils and microtopography and facilitates invasive plants in sedge meadows of southern Wisconsin: University of WisconsinMadison, unpublished M.S. thesis, 79 p.

Werner K.J., and Zedler, J.B., 2002, How sedge meadow soils, microtopography, and vegetation respond to sedimentation: Wetlands, v. 22, no. 3, p. 451-466.
Wilde, F.D., and Radtke, D.B., eds., 1998, Field measurements-National field manual for the collection of waterquality data: U.S. Geological Survey Techniques of WaterResources Investigations, book 9, chap. A6 [variously paged].

Wilhelm, G.S., and Masters, Linda, 2006, Floristic quality assessment and computer applications: Elmhurst, Ill., Conservation Research Institute, 37 p.

Woo, Isa, and Zedler, J.B., 2002, Can nutrients alone shift a sedge meadow towards the invasive Typha $\times$ glauca?: Wetlands, v. 22, no. 3, p. 509-521. 


\section{Glossary}

average wetness A measure of the affiliation of a plant community for wet conditions, made by quantifying and averaging the indicator status of plants, as discussed in the U.S. Army Corps of Engineers Wetland Delineation Manual.

coefficient of conservatism An estimate of the degree to which a species has a high tendency to occur only in a specific habitat type. The scores are mainly reflective of a plant's susceptibility to ecological change, with 0 being minimally susceptible and 10 being highly susceptible.

dry, mesic, wet (and combinations) prairie Prairies are communities dominated by grasses on organic or mineral soils. Trees may be present, but less than 10 percent of the area has tree cover. Dry prairies have a high density of herbaceous flowering plants and low percentage of grass cover. Mesic prairie is a native grassland community dominated by big bluestem, little bluestem, and Indian grass (Sorghastrum nutans) that occurs on loam, sandy loam or silt loam soils on level or slightly undulating glacial outwash. Wet prairie is an herbaceous wetland typically dominated by graminoid species such as prairie cordgrass, bluejoint, and sedges. Vegetation height is often 6-9 ft. Wet prairies occur in deep swales, and the substrate ranges from very deep black mineral soils (which are high in organic matter) to muck. Ponding in spring lasts for several weeks prior to drainage.

dune and swale An ecological system consisting of a mixture of upland and wetland natural communities. These communities occur in long, narrow, linear complexes, with the dry communities occupying sand ridges and the wet communities occurring in the intervening swales. Trees and prairie vegetation typically occur on the ridges, and sedges, reeds, and marsh/aquatic vegetation line are found in the swales. Water levels are directly influenced by groundwater, with the interdunal swales controlled largely by lateral flow through porous beach ridges.

emergent marsh Cyclical wetland dominated by emergent reeds and grasses and other aquatic plants. Vegetation and wildlife composition varies spatially with water depth. The stages of the marsh cycle form a continuum from a ponded state-in which open water covers all but the marsh's shallow edges - to a closed, 100-percent cover by emergent vegetation. Maximum structural diversity of importance for wetland birds is reached where the surface is approximately 50 percent open water and 50 percent emergent vegetation. This is called the hemi-marsh stage, and in it these two structural features are completely interspersed to maximize the internal interface between water and vegetation. eutrophication The process by which lakes gradually age and become more productive due to an increase in compounds containing nitrogen or phosphorus. An increase in the lake's primary productivity is accompanied by excessive plant growth and decay, which can have further effects including lack of oxygen and severe reductions in water quality, fish, and other animal populations.

fen A calcareous, groundwater-fed wetland typically located in the vicinity of glacial moraines and containing a muck or peat substrate. Fens support many plants adapted to high concentrations of dissolved alkaline minerals.

floristic quality (assessment index) A statistic designed to reduce subjectivity and create a standard means of expressing vegetation quality that may be used to compare sites and to assess the quality of a site through time. Often used to assess the degree to which a site has been impacted by human disturbance. The index is the mean coefficient of conservatism times the square root of the total number of native species at a site.

foredune A coastal dune or ridge that is parallel to the shoreline of a large lake or ocean and is stabilized by vegetation.

hydroperiod A measure of the depth and duration of inundation or saturation as measured above or below a given datum; often depicted as a graphic of surface or groundwater levels through time at a given point relative to land surface or summed to make a value of inundation or saturation at a given location.

importance value A measure of the relative dominance of a species in an ecological community. Importance values rank species within an area on the basis of how commonly a species occurs across the entire community, the total number of individuals of the species, and the total amount of area occupied by the species.

inundation duration Period of time in which a given area contains standing water.

panne Groundwater-fed interdunal wetland occupying calcareous, moist sands of the lake plain, generally within 1 mile of Lake Michigan. Sedges and sedge relatives dominate this open-structured wetland, which has considerable floristic overlap with fens and calcareous seeps.

quadrat A rectangle or square of known dimensions typically used by ecologists to define an area within which the number and type of vegetation is counted.

residence time Average time water spends in a specified region of space. For purposes of this report, residence time refers to the amount of time surface water spends in the various parts of the wetland complex. 
sand prairie Herbaceous wetland typically dominated by graminoid species such as prairie cordgrass, bluejoint, and sedges with a sand substrate. Flooding is a regular springtime occurrence and may last several weeks.

sand savannah Grassland region with scattered trees, grading into either open plain or woodland with a sand substrate.

sedge meadows Sedge-dominated grasslands that include wet-prairie grasses. Groundwater seepage and/or shallow flooding are the principal hydrological factors, and frequent fire is needed to retain sedge meadows' open structure. Sedge meadows often grade into fens, marshes, or wet prairies.

species richness index A measurement of the total number of species present in an ecosystem. specific yield A ratio, less than or equal to the effective porosity, indicating the volumetric fraction of the bulk aquifer volume that a given aquifer will yield when all the water is allowed to drain out of it under the forces of gravity. Value is 1 for surface-water bodies.

suspended sediment Particulate organic and inorganic matter suspended in or carried by water.

tussock A compact tuft, especially of sedge or grass.

upland prairie Topographically elevated ecosystem dominated by herbaceous plants other than grasses or sedges on moderately well drained to excessively drained soils. 


\section{Appendix 1. Water-Level Measurements in the Vicinity of Spring Bluff Nature Preserve, Lake County, Illinois}


Table 1-1. Water-level elevation at gages and in wells in the vicinity of Spring Bluff Nature Preserve, Lake County, Illinois.

$[\mathrm{nm}$, not measured; bold denotes ice present; underline denotes gage is dry, value is maximum possible water level; *, flow on river at gage DR3; bold and underline denotes gage was submerged, value is minimum possible water level]

\begin{tabular}{|c|c|c|c|c|c|c|c|c|c|c|c|c|c|}
\hline \multirow{2}{*}{$\begin{array}{l}\text { Gage } \\
\text { or well }\end{array}$} & \multirow{2}{*}{$\begin{array}{c}\text { Elevation } \\
\text { of top of } \\
\text { casing } \\
\text { (feet) }\end{array}$} & \multirow{2}{*}{$\begin{array}{c}\text { Elevation } \\
\text { of land } \\
\text { surface } \\
\text { (feet) }\end{array}$} & \multicolumn{11}{|c|}{ Water-level elevation, in feet above North American Vertical Datum of 1988, on given date } \\
\hline & & & $07 / 24 / 2007$ & 07/26/2007 & 08/20/2007 & 08/23/2007 & 09/11/2007 & 09/18/2007 & $10 / 18 / 2007$ & $10 / 29 / 2007$ & $11 / 08 / 2007$ & 11/16/2007 & $11 / 22 / 2007$ \\
\hline Gage B & 589.34 & 585.34 & $\mathrm{~nm}$ & $\mathrm{~nm}$ & 586.54 & 586.80 & 586.00 & 585.77 & 585.77 & 585.71 & 585.46 & 585.36 & $\mathrm{~nm}$ \\
\hline Well 1 & 588.98 & 585.32 & 584.53 & 584.39 & 586.54 & 586.72 & 585.98 & 585.76 & 585.77 & 585.70 & 585.46 & 585.28 & 585.24 \\
\hline Well 2 & 591.75 & 588.51 & $\mathrm{~nm}$ & $\mathrm{~nm}$ & 586.51 & 586.79 & 585.95 & 585.59 & 585.52 & $\mathrm{~nm}$ & $\mathrm{~nm}$ & $\mathrm{~nm}$ & $\mathrm{~nm}$ \\
\hline Well 3 & 589.37 & 585.24 & 584.20 & 584.08 & 586.57 & 586.80 & 585.99 & 585.63 & 585.46 & 585.29 & 585.02 & 584.80 & 584.74 \\
\hline Well 4 & 591.42 & 588.70 & $\mathrm{~nm}$ & $\mathrm{~nm}$ & 586.57 & 586.80 & 585.78 & 585.39 & 585.08 & $\mathrm{~nm}$ & $\mathrm{~nm}$ & $\mathrm{~nm}$ & $\mathrm{~nm}$ \\
\hline Well 5 & 588.92 & 584.88 & 583.57 & 583.46 & 586.68 & 586.73 & 585.60 & 585.22 & 584.60 & 584.17 & 583.91 & 583.74 & 583.72 \\
\hline Gage C & 588.84 & 584.81 & $\mathrm{~nm}$ & $\mathrm{~nm}$ & 586.68 & 586.79 & 585.60 & 585.21 & $\mathrm{~nm}$ & $\mathrm{~nm}$ & $\mathrm{~nm}$ & $\mathrm{~nm}$ & $\mathrm{~nm}$ \\
\hline Well 6 & 593.88 & 589.98 & 587.96 & 587.87 & 589.55 & 589.64 & 589.27 & 588.91 & 589.24 & 589.06 & 588.98 & 589.00 & $\mathrm{~nm}$ \\
\hline Gage D & 593.02 & 589.07 & $\mathrm{~nm}$ & $\mathrm{~nm}$ & 589.15 & 589.22 & & $\mathrm{~nm}$ & $\mathrm{~nm}$ & $\mathrm{~nm}$ & $\mathrm{~nm}$ & $\mathrm{~nm}$ & $\mathrm{~nm}$ \\
\hline Well 7 & 592.97 & 589.05 & 587.04 & 586.92 & 589.18 & 589.18 & 588.80 & 588.46 & 588.38 & 588.70 & 588.56 & 588.53 & 588.58 \\
\hline Well 8 & 593.11 & 589.12 & $\mathrm{~nm}$ & $\mathrm{~nm}$ & 588.65 & 588.68 & 588.05 & 587.66 & 588.15 & 588.01 & 587.92 & 587.88 & 587.92 \\
\hline Well 9 & 591.13 & 587.46 & 586.02 & 585.89 & 588.24 & 588.15 & 587.77 & 587.52 & 587.85 & 587.77 & 587.65 & 587.64 & 587.65 \\
\hline Gage E & 591.23 & 587.19 & $\mathrm{~nm}$ & $\mathrm{~nm}$ & 588.26 & 588.33 & 587.79 & 587.53 & 587.87 & 587.89 & 587.71 & 587.65 & 587.66 \\
\hline Well 10 & 592.20 & 588.30 & $\mathrm{~nm}$ & $\mathrm{~nm}$ & 588.25 & 587.22 & 587.75 & 587.45 & 587.87 & 587.77 & 587.68 & 587.61 & 587.61 \\
\hline Well 11 & 592.88 & 588.86 & $\mathrm{~nm}$ & $\mathrm{~nm}$ & & 588.28 & 587.52 & 587.29 & 587.84 & 587.68 & 587.52 & 587.44 & 587.42 \\
\hline Gage F & 589.51 & 585.51 & $\mathrm{~nm}$ & $\mathrm{~nm}$ & 589.21 & 588.21 & 587.47 & 587.18 & 588.41 & 587.54 & 587.36 & 587.23 & 587.21 \\
\hline Well 12 & 590.08 & 585.79 & 585.83 & 585.73 & 588.25 & 588.15 & 587.52 & 587.22 & 587.82 & 588.04 & 587.40 & 587.27 & 587.25 \\
\hline Well 13 & 592.59 & 588.65 & $\mathrm{~nm}$ & $\mathrm{~nm}$ & 587.59 & 587.77 & 587.11 & 586.37 & 587.27 & 587.03 & 586.96 & 586.94 & 587.09 \\
\hline Well 14 & 590.41 & 586.62 & 585.83 & 585.69 & 586.98 & 587.12 & 586.68 & 586.16 & 586.82 & 586.70 & 586.67 & 586.60 & 586.71 \\
\hline Gage G & 590.49 & 586.54 & $\mathrm{~nm}$ & $\mathrm{~nm}$ & 586.99 & 587.14 & 586.67 & $\mathrm{~nm}$ & 586.81 & 586.67 & 586.63 & 586.59 & 586.67 \\
\hline Well 15 & 592.59 & 588.50 & $\mathrm{~nm}$ & $\mathrm{~nm}$ & 587.21 & 587.20 & 586.61 & $\mathrm{~nm}$ & 586.65 & 586.40 & 586.28 & 586.25 & 586.39 \\
\hline Well 16 & 590.84 & 586.91 & 584.56 & 584.41 & 587.48 & 587.55 & 586.48 & 585.76 & 586.45 & 586.02 & 585.84 & 585.76 & 585.92 \\
\hline Well 17 & 591.37 & 588.33 & $\mathrm{~nm}$ & $\mathrm{~nm}$ & 586.99 & 587.09 & 586.11 & 585.54 & 585.84 & 585.49 & 585.21 & 585.13 & 585.22 \\
\hline Well 18 & 589.18 & 585.41 & 584.23 & 584.10 & 586.90 & 586.90 & 586.04 & 585.54 & 585.75 & 585.45 & 585.14 & 585.17 & 585.13 \\
\hline Gage H & 589.46 & 585.47 & $\mathrm{~nm}$ & $\mathrm{~nm}$ & 586.88 & 586.90 & 586.02 & 585.54 & 585.74 & $\mathrm{~nm}$ & $\mathrm{~nm}$ & $\mathrm{~nm}$ & $\mathrm{~nm}$ \\
\hline Well 19 & 586.98 & 583.10 & $\mathrm{~nm}$ & $\mathrm{~nm}$ & $\mathrm{~nm}$ & $\mathrm{~nm}$ & $\mathrm{~nm}$ & $\mathrm{~nm}$ & $\mathrm{~nm}$ & $\mathrm{~nm}$ & 580.99 & 580.86 & 580.83 \\
\hline Well 20 & 587.99 & 584.00 & $\mathrm{~nm}$ & $\mathrm{~nm}$ & $\mathrm{~nm}$ & $\mathrm{~nm}$ & $\mathrm{~nm}$ & $\mathrm{~nm}$ & $\mathrm{~nm}$ & $\mathrm{~nm}$ & 583.58 & 583.58 & 583.63 \\
\hline Well 21 & 587.30 & 583.41 & $\mathrm{~nm}$ & $\mathrm{~nm}$ & $\mathrm{~nm}$ & $\mathrm{~nm}$ & $\mathrm{~nm}$ & $\mathrm{~nm}$ & $\mathrm{~nm}$ & $\mathrm{~nm}$ & 583.53 & 583.50 & 583.53 \\
\hline Gage A & 587.37 & 583.21 & $\mathrm{~nm}$ & $\mathrm{~nm}$ & $\mathrm{~nm}$ & $\mathrm{~nm}$ & $\mathrm{~nm}$ & $\mathrm{~nm}$ & $\mathrm{~nm}$ & $\mathrm{~nm}$ & 583.50 & 583.49 & 583.51 \\
\hline Well 22 & 587.55 & 583.61 & $\mathrm{~nm}$ & $\mathrm{~nm}$ & $\mathrm{~nm}$ & $\mathrm{~nm}$ & $\mathrm{~nm}$ & $\mathrm{~nm}$ & $\mathrm{~nm}$ & $\mathrm{~nm}$ & 583.52 & 583.50 & 583.52 \\
\hline
\end{tabular}


Table 1-1. Water-level elevation at gages and in wells in the vicinity of Spring Bluff Nature Preserve, Lake County, Illinois. —Continued

[nm, not measured; bold denotes ice present; underline denotes gage is dry, value is maximum possible water level; *, flow on river at gage DR3; bold and underline denotes gage was submerged, value is minimum possible water level]

\begin{tabular}{|c|c|c|c|c|c|c|c|c|c|c|c|c|c|}
\hline \multirow{2}{*}{$\begin{array}{l}\text { Gage } \\
\text { or well }\end{array}$} & \multirow{2}{*}{$\begin{array}{c}\text { Elevation } \\
\text { of top of } \\
\text { casing } \\
\text { (feet) }\end{array}$} & \multirow{2}{*}{$\begin{array}{c}\text { Elevation } \\
\text { of land } \\
\text { surface } \\
\text { (feet) }\end{array}$} & \multicolumn{11}{|c|}{ Water-level elevation, in feet above North American Vertical Datum of 1988, on given date } \\
\hline & & & 11/27/2007 & 12/06/2007 & $12 / 14 / 2007$ & 12/19/2007 & 12/31/2007 & 01/09/2008 & $01 / 22 / 2008$ & 02/13/2008 & 03/13/2008 & 03/17/2008 & 03/25/2008 \\
\hline Gage B & 589.34 & 585.34 & $\mathrm{~nm}$ & $\mathrm{~nm}$ & $\mathrm{~nm}$ & $\mathrm{~nm}$ & $\mathrm{~nm}$ & 586.10 & $\mathrm{~nm}$ & $\mathrm{~nm}$ & $\mathrm{~nm}$ & 586.93 & 586.90 \\
\hline Well 1 & 588.98 & 585.32 & 585.20 & $\mathrm{~nm}$ & $\mathrm{~nm}$ & $\mathrm{~nm}$ & $\mathrm{~nm}$ & 586.08 & $\mathrm{~nm}$ & $\mathrm{~nm}$ & 586.77 & 586.88 & 586.93 \\
\hline Well 2 & 591.75 & 588.51 & $\mathrm{~nm}$ & $\mathrm{~nm}$ & 585.42 & 585.40 & 585.74 & 586.05 & 586.04 & $\mathrm{~nm}$ & 586.75 & 586.90 & 586.98 \\
\hline Well 3 & 589.37 & 585.24 & 584.68 & 585.03 & 585.31 & $\mathrm{~nm}$ & $\mathrm{~nm}$ & 586.13 & $\mathrm{~nm}$ & $\mathrm{~nm}$ & 586.73 & 586.87 & 586.89 \\
\hline Well 4 & 591.42 & 588.70 & $\mathrm{~nm}$ & $\mathrm{~nm}$ & $\mathrm{~nm}$ & $\mathrm{~nm}$ & 585.33 & 586.04 & 585.85 & $\mathrm{~nm}$ & 586.73 & 586.92 & 586.98 \\
\hline Well 5 & 588.92 & 584.88 & 583.61 & 583.93 & 584.14 & 583.99 & 584.81 & 586.02 & $\mathrm{~nm}$ & $\mathrm{~nm}$ & 586.70 & 586.90 & 586.91 \\
\hline Gage C & 588.84 & 584.81 & $\mathrm{~nm}$ & $\mathrm{~nm}$ & $\mathrm{~nm}$ & $\mathrm{~nm}$ & $\mathrm{~nm}$ & 586.02 & $\mathrm{~nm}$ & $\mathrm{~nm}$ & 584.84 & 586.89 & 586.89 \\
\hline Well 6 & 593.88 & 589.98 & 589.05 & 589.27 & 589.30 & 589.57 & 589.36 & 589.47 & $\mathrm{~nm}$ & 589.50 & 589.30 & 589.25 & 589.45 \\
\hline Gage D & 593.02 & 589.07 & $\mathrm{~nm}$ & 589.22 & $\mathrm{~nm}$ & 589.16 & 589.10 & 589.12 & $\mathrm{~nm}$ & $\mathrm{~nm}$ & $\mathrm{~nm}$ & 589.13 & 589.22 \\
\hline Well 7 & 592.97 & 589.05 & 588.67 & 588.93 & 589.06 & 589.01 & 589.12 & 589.17 & $\mathrm{~nm}$ & $\mathrm{~nm}$ & $\mathrm{~nm}$ & $\mathrm{~nm}$ & 589.95 \\
\hline Well 8 & 593.11 & 589.12 & 587.97 & 588.22 & 588.36 & 588.28 & 588.35 & 588.53 & $\mathrm{~nm}$ & 588.85 & $\mathrm{~nm}$ & $\mathrm{~nm}$ & $\mathrm{~nm}$ \\
\hline Well 9 & 591.13 & 587.46 & 587.73 & 587.93 & $\mathrm{~nm}$ & $\mathrm{~nm}$ & 588.01 & 588.11 & $\mathrm{~nm}$ & $\mathrm{~nm}$ & $\mathrm{~nm}$ & 588.11 & 588.18 \\
\hline Gage E & 591.23 & 587.19 & 587.73 & 587.89 & 587.97 & 587.93 & 587.98 & 588.09 & $\mathrm{~nm}$ & $\mathrm{~nm}$ & $\mathrm{~nm}$ & 588.18 & 588.15 \\
\hline Well 10 & 592.20 & 588.30 & 587.65 & 587.91 & 587.98 & 587.92 & 587.96 & 588.12 & 587.87 & $\mathrm{~nm}$ & $\mathrm{~nm}$ & $\mathrm{~nm}$ & 588.22 \\
\hline Well 11 & 592.88 & 588.86 & 587.45 & 587.90 & 588.01 & 587.91 & 588.00 & 588.17 & 587.57 & 589.13 & $\mathrm{~nm}$ & $\mathrm{~nm}$ & 589.51 \\
\hline Gage F & 589.51 & 585.51 & 587.27 & 587.85 & $\mathrm{~nm}$ & $\mathrm{~nm}$ & $\mathrm{~nm}$ & 588.09 & 587.75 & $\mathrm{~nm}$ & $\mathrm{~nm}$ & 588.05 & 587.96 \\
\hline Well 12 & 590.08 & 585.79 & 587.31 & $\mathrm{~nm}$ & $\mathrm{~nm}$ & $\mathrm{~nm}$ & $\mathrm{~nm}$ & 588.12 & $\mathrm{~nm}$ & $\mathrm{~nm}$ & $\mathrm{~nm}$ & 588.00 & 587.95 \\
\hline Well 13 & 592.59 & 588.65 & 587.05 & 587.27 & 587.35 & 587.27 & 587.31 & 587.52 & 587.15 & 587.61 & 587.82 & 587.63 & 588.28 \\
\hline Well 14 & 590.41 & 586.62 & 586.74 & $\mathrm{~nm}$ & $\mathrm{~nm}$ & 586.80 & $\mathrm{~nm}$ & 586.97 & $\mathrm{~nm}$ & $\mathrm{~nm}$ & $\mathrm{~nm}$ & 586.99 & 587.15 \\
\hline Gage G & 590.49 & 586.54 & 586.69 & $\mathrm{~nm}$ & $\mathrm{~nm}$ & 586.87 & $\mathrm{~nm}$ & 586.97 & $\mathrm{~nm}$ & $\mathrm{~nm}$ & $\mathrm{~nm}$ & 587.00 & 587.15 \\
\hline Well 15 & 592.59 & 588.50 & 586.36 & 586.64 & 586.75 & 586.66 & 586.85 & 587.11 & 586.68 & 586.99 & 587.29 & 587.18 & 587.43 \\
\hline Well 16 & 590.84 & 586.91 & 585.91 & 586.44 & 586.63 & 586.49 & & 587.19 & $\mathrm{~nm}$ & $\mathrm{~nm}$ & 587.52 & 587.47 & 587.56 \\
\hline Well 17 & 591.37 & 588.33 & 585.27 & 585.80 & 586.04 & 585.95 & 586.44 & 586.70 & 586.13 & 586.46 & 587.07 & 586.97 & 587.52 \\
\hline Well 18 & 589.18 & 585.41 & 585.19 & 585.71 & $\mathrm{~nm}$ & $\mathrm{~nm}$ & $\mathrm{~nm}$ & 586.63 & $\mathrm{~nm}$ & $\mathrm{~nm}$ & 586.89 & 586.91 & 586.98 \\
\hline Gage H & 589.46 & 585.47 & $\mathrm{~nm}$ & 585.72 & 585.95 & 585.94 & $\mathrm{~nm}$ & 586.60 & $\mathrm{~nm}$ & $\mathrm{~nm}$ & $\mathrm{~nm}$ & 588.05 & 587.98 \\
\hline Well 19 & 586.98 & 583.10 & 580.80 & 581.15 & 581.21 & 581.20 & 581.69 & 581.84 & 581.58 & $\mathrm{~nm}$ & 582.79 & 582.74 & 583.33 \\
\hline Well 20 & 587.99 & 584.00 & 583.60 & $\mathrm{~nm}$ & 583.68 & $\mathrm{~nm}$ & $\mathrm{~nm}$ & $\mathrm{~nm}$ & $\mathrm{~nm}$ & $\mathrm{~nm}$ & $\mathrm{~nm}$ & 583.96 & 583.99 \\
\hline Well 21 & 587.30 & 583.41 & 583.52 & $\mathrm{~nm}$ & 583.53 & $\mathrm{~nm}$ & $\mathrm{~nm}$ & $\mathrm{~nm}$ & $\mathrm{~nm}$ & $\mathrm{~nm}$ & $\mathrm{~nm}$ & $\mathrm{~nm}$ & 583.89 \\
\hline Gage A & 587.37 & 583.21 & 583.51 & $\mathrm{~nm}$ & $\mathrm{~nm}$ & $\mathrm{~nm}$ & $\mathrm{~nm}$ & $\mathrm{~nm}$ & 587.03 & $\mathrm{~nm}$ & 583.37 & 583.37 & 583.87 \\
\hline Well 22 & 587.55 & 583.61 & 583.50 & $\mathrm{~nm}$ & 583.56 & $\mathrm{~nm}$ & $\mathrm{~nm}$ & $\mathrm{~nm}$ & 583.81 & $\mathrm{~nm}$ & 584.09 & 583.88 & 583.94 \\
\hline
\end{tabular}


$[\mathrm{nm}$, not measured; bold denotes ice present; underline denotes gage is dry, value is maximum possible water level; *, flow on river at gage DR3; bold and underline denotes gage was submerged, value is minimum possible water level]

\begin{tabular}{|c|c|c|c|c|c|c|c|c|c|c|c|}
\hline \multirow{2}{*}{$\begin{array}{l}\text { Gage } \\
\text { or well }\end{array}$} & \multirow{2}{*}{$\begin{array}{c}\text { Elevation } \\
\text { of top of } \\
\text { casing } \\
\text { (feet) }\end{array}$} & \multirow{2}{*}{$\begin{array}{c}\text { Elevation } \\
\text { of land } \\
\text { surface } \\
\text { (feet) }\end{array}$} & \multicolumn{9}{|c|}{ Water-level elevation, in feet above North American Vertical Datum of 1988, on given date } \\
\hline & & & 03/26/2008 & 04/09/2008 & 04/29/2008 & 05/05/2008 & 05/13/2008 & 06/05/2008 & $06 / 11 / 2008$ & 07/07/2008 & $08 / 27 / 2008$ \\
\hline Gage B & 589.34 & 585.34 & 587.02 & 586.96 & 587.74 & 586.54 & 586.42 & 586.34 & $\mathrm{~nm}$ & 586.31 & $\mathrm{~nm}$ \\
\hline Well 1 & 588.98 & 585.32 & 587.03 & 586.95 & 587.75 & 586.54 & 586.43 & 586.35 & $\mathrm{~nm}$ & 586.30 & 584.77 \\
\hline Well 2 & 591.75 & 588.51 & 587.02 & 586.95 & 586.55 & 586.52 & 586.38 & 586.31 & $\mathrm{~nm}$ & 586.24 & $\mathrm{~nm}$ \\
\hline Well 3 & 589.37 & 585.24 & 586.99 & 586.92 & 586.55 & 586.50 & 586.39 & 586.32 & $\mathrm{~nm}$ & 586.26 & 584.77 \\
\hline Well 4 & 591.42 & 588.70 & 587.02 & 586.92 & 586.50 & 586.43 & 586.30 & 586.26 & $\mathrm{~nm}$ & 586.15 & $\mathrm{~nm}$ \\
\hline Well 5 & 588.92 & 584.88 & 587.03 & 585.96 & 586.48 & 586.36 & 586.21 & 586.14 & $\mathrm{~nm}$ & 586.05 & 584.24 \\
\hline Gage C & 588.84 & 584.81 & 586.80 & 586.85 & 586.45 & 586.36 & 586.19 & 586.12 & $\mathrm{~nm}$ & 586.01 & $\mathrm{~nm}$ \\
\hline Well 6 & 593.88 & 589.98 & 589.30 & 589.35 & 589.22 & 589.19 & 589.50 & 589.67 & $\mathrm{~nm}$ & 589.48 & 587.97 \\
\hline Gage D & 593.02 & 589.07 & 589.20 & 589.19 & 589.10 & 589.09 & $\mathrm{~nm}$ & 589.12 & $\mathrm{~nm}$ & $\mathrm{~nm}$ & $\mathrm{~nm}$ \\
\hline Well 7 & 592.97 & 589.05 & 589.92 & 589.91 & 589.82 & 589.78 & 589.80 & 589.84 & $\mathrm{~nm}$ & 589.67 & 587.73 \\
\hline Well 8 & 593.11 & 589.12 & $\mathrm{~nm}$ & 588.56 & 588.34 & 588.29 & 588.37 & 588.52 & $\mathrm{~nm}$ & 588.22 & $\mathrm{~nm}$ \\
\hline Well 9 & 591.13 & 587.46 & 588.29 & 588.31 & 588.11 & 588.06 & 588.02 & 588.03 & $\mathrm{~nm}$ & 587.91 & 585.92 \\
\hline Gage E & 591.23 & 587.19 & 588.27 & 588.30 & 588.09 & 588.08 & 588.01 & 588.03 & $\mathrm{~nm}$ & 587.88 & $\mathrm{~nm}$ \\
\hline Well 10 & 592.20 & 588.30 & 588.20 & 588.23 & 588.02 & 588.00 & 587.93 & 587.98 & $\mathrm{~nm}$ & 587.81 & $\mathrm{~nm}$ \\
\hline Well 11 & 592.88 & 588.86 & $\mathrm{~nm}$ & 589.32 & 589.03 & 589.03 & 589.01 & 587.07 & $\mathrm{~nm}$ & 588.86 & $\mathrm{~nm}$ \\
\hline Gage F & 589.51 & 585.51 & 588.27 & 588.26 & 587.85 & 587.85 & 587.76 & 587.77 & $\mathrm{~nm}$ & 587.51 & $\mathrm{~nm}$ \\
\hline Well 12 & 590.08 & 585.79 & 588.22 & 587.22 & 587.81 & 587.78 & 587.72 & 587.72 & $\mathrm{~nm}$ & 587.58 & 585.45 \\
\hline Well 13 & 592.59 & 588.65 & 586.76 & 587.74 & 587.28 & 587.27 & 587.22 & 587.69 & $\mathrm{~nm}$ & 587.33 & $\mathrm{~nm}$ \\
\hline Well 14 & 590.41 & 586.62 & 587.13 & 587.16 & 586.91 & 586.89 & 586.90 & 586.98 & $\mathrm{~nm}$ & 586.80 & 585.00 \\
\hline Gage G & 590.49 & 586.54 & 587.14 & 586.56 & 586.91 & 586.92 & 586.89 & 586.99 & $\mathrm{~nm}$ & 586.76 & $\mathrm{~nm}$ \\
\hline Well 15 & 592.59 & 588.50 & 587.23 & 587.24 & 586.81 & 586.78 & 586.72 & 586.98 & $\mathrm{~nm}$ & 586.69 & $\mathrm{~nm}$ \\
\hline Well 16 & 590.84 & 586.91 & 587.51 & 587.50 & 586.93 & 586.89 & 586.70 & 586.87 & $\mathrm{~nm}$ & 586.53 & $\mathrm{~nm}$ \\
\hline Well 17 & 591.37 & 588.33 & 587.06 & 587.01 & 586.61 & 586.62 & 586.50 & 586.57 & $\mathrm{~nm}$ & 586.26 & $\mathrm{~nm}$ \\
\hline Well 18 & 589.18 & 585.41 & 586.94 & 586.89 & 586.65 & 586.62 & 586.51 & 586.24 & $\mathrm{~nm}$ & 586.18 & 584.41 \\
\hline Gage H & 589.46 & 585.47 & 588.00 & 588.06 & 588.30 & 588.32 & 588.44 & 588.70 & $\mathrm{~nm}$ & 588.83 & $\mathrm{~nm}$ \\
\hline Well 19 & 586.98 & 583.10 & 583.30 & 583.37 & 583.29 & 583.27 & 583.91 & $\mathrm{~nm}$ & 583.33 & 582.88 & 581.25 \\
\hline Well 20 & 587.99 & 584.00 & 584.88 & 583.84 & 583.77 & 583.75 & 583.74 & $\mathrm{~nm}$ & 583.79 & 583.85 & 583.23 \\
\hline Well 21 & 587.30 & 583.41 & 583.74 & 583.59 & 583.57 & 583.55 & 583.57 & $\mathrm{~nm}$ & 583.59 & 583.65 & 583.32 \\
\hline Gage A & 587.37 & 583.21 & 583.74 & 583.55 & 583.54 & 583.53 & 583.53 & $\mathrm{~nm}$ & 583.54 & 583.59 & $\mathrm{~nm}$ \\
\hline Well 22 & 587.55 & 583.61 & 583.82 & 583.75 & 583.69 & 583.68 & 583.68 & $\mathrm{~nm}$ & 583.74 & 583.74 & 583.34 \\
\hline
\end{tabular}


Table 1-2. Depth to water at gages and in wells in the vicinity of Spring Bluff Nature Preserve, Lake County, Illinois.

[nm, not measured; bold denotes ice present; underline denotes gage is dry, value is maximum possible water level; *, flow on river at gage DR3; bold and underline denotes gage is submerged, value is minimum possible water level]

\begin{tabular}{|c|c|c|c|c|c|c|c|c|c|c|c|c|c|}
\hline \multirow{2}{*}{$\begin{array}{c}\text { Gage } \\
\text { or well }\end{array}$} & \multirow{2}{*}{$\begin{array}{c}\text { Elevation } \\
\text { of top of } \\
\text { casing } \\
\text { (feet) }\end{array}$} & \multirow{2}{*}{$\begin{array}{c}\text { Elevation } \\
\text { of land } \\
\text { surface } \\
\text { (feet) }\end{array}$} & \multicolumn{11}{|c|}{ Depth to water in feet above (negative value) and below (positive value) land surface on given date } \\
\hline & & & $07 / 25 / 2007$ & 07/27/2007 & 08/21/2007 & 08/24/2007 & 09/12/2007 & 09/19/2007 & 10/19/2007 & 10/30/2007 & 11/09/2007 & $11 / 17 / 2007$ & $11 / 23 / 2007$ \\
\hline Gage B & 589.34 & 585.34 & $\mathrm{~nm}$ & $\mathrm{~nm}$ & -1.20 & -1.46 & -0.66 & -0.43 & -0.43 & -0.37 & -0.12 & -0.02 & $\mathrm{~nm}$ \\
\hline Well 1 & 588.98 & 585.32 & 0.78 & 0.92 & -1.23 & -1.41 & -0.67 & -0.45 & -0.46 & -0.38 & -0.15 & 0.03 & 0.07 \\
\hline Well 2 & 591.75 & 588.51 & 0.00 & 0.00 & 2.00 & 1.72 & 2.56 & 2.92 & 2.99 & $\mathrm{~nm}$ & $\mathrm{~nm}$ & $\mathrm{~nm}$ & $\mathrm{~nm}$ \\
\hline Well 3 & 589.37 & 585.24 & 1.04 & 1.16 & -1.33 & -1.56 & -0.75 & -0.39 & -0.22 & -0.05 & 0.22 & 0.44 & 0.50 \\
\hline Well 4 & 591.42 & 588.70 & 0.00 & 0.00 & 2.13 & 1.90 & 2.92 & 3.31 & 3.62 & $\mathrm{~nm}$ & $\mathrm{~nm}$ & $\mathrm{~nm}$ & $\mathrm{~nm}$ \\
\hline Well 5 & 588.92 & 584.88 & 1.30 & 1.41 & -1.80 & -1.85 & -0.73 & -0.35 & 0.27 & 0.70 & 0.96 & 1.13 & 1.15 \\
\hline Gage C & 588.84 & 584.81 & 0.00 & 0.00 & -1.84 & -1.95 & -0.76 & -0.37 & $\mathrm{~nm}$ & $\mathrm{~nm}$ & $\mathrm{~nm}$ & $\mathrm{~nm}$ & $\mathrm{~nm}$ \\
\hline Well 6 & 593.88 & 589.98 & 2.01 & 2.10 & 0.42 & 0.33 & 0.70 & 1.06 & 0.73 & 0.91 & 0.99 & 0.97 & 0.00 \\
\hline Gage D & 593.02 & 589.07 & $\mathrm{~nm}$ & $\mathrm{~nm}$ & -0.13 & -0.20 & 0.00 & $\mathrm{~nm}$ & $\mathrm{~nm}$ & $\mathrm{~nm}$ & $\mathrm{~nm}$ & $\mathrm{~nm}$ & $\mathrm{~nm}$ \\
\hline Well 7 & 592.97 & 589.05 & 2.02 & 2.14 & -0.12 & -0.12 & 0.26 & 0.60 & $\mathrm{~nm}$ & 0.36 & 0.50 & 0.53 & 0.48 \\
\hline Well 8 & 593.11 & 589.12 & 0.00 & 0.00 & 0.48 & 0.45 & 1.08 & 1.47 & 0.98 & 1.12 & 1.21 & 1.25 & 1.21 \\
\hline Well 9 & 591.13 & 587.46 & 1.44 & 1.57 & -0.79 & -0.70 & -0.32 & -0.07 & -0.40 & -0.32 & -0.20 & -0.19 & -0.20 \\
\hline Gage E & 591.23 & 587.19 & $\mathrm{~nm}$ & $\mathrm{~nm}$ & -1.03 & -1.10 & -0.56 & -0.30 & -0.64 & -0.66 & -0.48 & -0.42 & -0.43 \\
\hline Well 10 & 592.20 & 588.30 & $\mathrm{~nm}$ & $\mathrm{~nm}$ & 0.05 & 1.08 & 0.55 & 0.85 & 0.43 & 0.53 & 0.62 & 0.69 & 0.69 \\
\hline Well 11 & 592.88 & 588.86 & $\mathrm{~nm}$ & $\mathrm{~nm}$ & $\mathrm{~nm}$ & 0.57 & 1.33 & 1.56 & 1.01 & 1.17 & 1.33 & 1.41 & 1.43 \\
\hline Gage F & 589.51 & 585.51 & $\mathrm{~nm}$ & $\mathrm{~nm}$ & $\mathrm{~nm}$ & -2.70 & -1.96 & -1.67 & -2.90 & -2.03 & -1.85 & -1.72 & -1.70 \\
\hline Well 12 & 590.08 & 585.79 & -0.04 & 0.06 & -2.46 & -2.36 & -1.73 & -1.43 & -2.03 & $\mathrm{~nm}$ & -1.61 & -1.48 & -1.46 \\
\hline Well 13 & 592.59 & 588.65 & $\mathrm{~nm}$ & $\mathrm{~nm}$ & 1.05 & 0.88 & 1.54 & 2.28 & 1.38 & 1.62 & 1.69 & 1.71 & 1.56 \\
\hline Well 14 & 590.41 & 586.62 & 0.79 & 0.93 & -0.36 & -0.50 & -0.06 & 0.46 & -0.20 & -0.08 & -0.05 & 0.02 & -0.09 \\
\hline Gage G & 590.49 & 586.54 & $\mathrm{~nm}$ & $\mathrm{~nm}$ & -0.50 & -0.65 & -0.18 & $\mathrm{~nm}$ & -0.32 & -0.18 & -0.14 & -0.10 & -0.18 \\
\hline Well 15 & 592.59 & 588.50 & $\mathrm{~nm}$ & $\mathrm{~nm}$ & 1.29 & 1.30 & 1.89 & $\mathrm{~nm}$ & 1.85 & 2.10 & 2.22 & 2.25 & 2.11 \\
\hline Well 16 & 590.84 & 586.91 & 2.35 & 2.50 & -0.57 & -0.64 & 0.43 & 1.15 & 0.46 & 0.89 & 1.07 & 1.15 & 0.99 \\
\hline Well 17 & 591.37 & 588.33 & $\mathrm{~nm}$ & $\mathrm{~nm}$ & 1.34 & 1.24 & 2.22 & 2.79 & 2.49 & 2.84 & 3.12 & 3.20 & 3.11 \\
\hline Well 18 & 589.18 & 585.41 & 1.18 & 1.31 & -1.49 & -1.49 & -0.63 & -0.13 & -0.34 & -0.04 & 0.27 & 0.24 & 0.28 \\
\hline Gage H & 589.46 & 585.47 & $\mathrm{~nm}$ & $\mathrm{~nm}$ & -1.42 & -1.44 & -0.56 & -0.08 & -0.28 & $\mathrm{~nm}$ & $\mathrm{~nm}$ & $\mathrm{~nm}$ & $\mathrm{~nm}$ \\
\hline Well 19 & 586.98 & 583.10 & $\mathrm{~nm}$ & $\mathrm{~nm}$ & $\mathrm{~nm}$ & $\mathrm{~nm}$ & $\mathrm{~nm}$ & $\mathrm{~nm}$ & $\mathrm{~nm}$ & $\mathrm{~nm}$ & 2.11 & 2.24 & 2.27 \\
\hline Well 20 & 587.99 & 584.00 & $\mathrm{~nm}$ & $\mathrm{~nm}$ & $\mathrm{~nm}$ & $\mathrm{~nm}$ & $\mathrm{~nm}$ & $\mathrm{~nm}$ & $\mathrm{~nm}$ & $\mathrm{~nm}$ & 0.42 & 0.42 & 0.37 \\
\hline Well 21 & 587.30 & 583.41 & $\mathrm{~nm}$ & $\mathrm{~nm}$ & $\mathrm{~nm}$ & $\mathrm{~nm}$ & $\mathrm{~nm}$ & $\mathrm{~nm}$ & $\mathrm{~nm}$ & $\mathrm{~nm}$ & -0.12 & -0.09 & -0.12 \\
\hline Gage A & 587.37 & 583.21 & $\mathrm{~nm}$ & $\mathrm{~nm}$ & $\mathrm{~nm}$ & $\mathrm{~nm}$ & $\mathrm{~nm}$ & $\mathrm{~nm}$ & $\mathrm{~nm}$ & $\mathrm{~nm}$ & -0.13 & -0.12 & -0.14 \\
\hline Well 22 & 587.55 & 583.61 & $\mathrm{~nm}$ & $\mathrm{~nm}$ & $\mathrm{~nm}$ & $\mathrm{~nm}$ & $\mathrm{~nm}$ & $\mathrm{~nm}$ & $\mathrm{~nm}$ & $\mathrm{~nm}$ & 0.08 & 0.10 & 0.08 \\
\hline
\end{tabular}


$[\mathrm{nm}$, not measured; bold denotes ice present; underline denotes gage is dry, value is maximum possible water level; *, flow on river at gage DR3; bold and underline denotes gage is submerged, value is minimum possible water level]

\begin{tabular}{|c|c|c|c|c|c|c|c|c|c|c|c|c|c|}
\hline \multirow{2}{*}{$\begin{array}{l}\text { Gage } \\
\text { or well }\end{array}$} & \multirow{2}{*}{$\begin{array}{c}\text { Elevation } \\
\text { of top of } \\
\text { casing } \\
\text { (feet) }\end{array}$} & \multirow{2}{*}{$\begin{array}{c}\text { Elevation } \\
\text { of land } \\
\text { surface } \\
\text { (feet) }\end{array}$} & \multicolumn{11}{|c|}{ Depth to water in feet above (negative value) and below (positive value) land surface on given date } \\
\hline & & & $11 / 28 / 2007$ & $12 / 07 / 2007$ & $12 / 15 / 2007$ & $12 / 20 / 2007$ & $01 / 01 / 2008$ & $01 / 10 / 2008$ & $01 / 23 / 2008$ & $02 / 14 / 2008$ & $03 / 14 / 2008$ & 03/18/2008 & $03 / 26 / 2008$ \\
\hline Gage B & 589.34 & 585.34 & $\mathrm{~nm}$ & $\mathrm{~nm}$ & $\mathrm{~nm}$ & $\mathrm{~nm}$ & $\mathrm{~nm}$ & -0.76 & $\mathrm{~nm}$ & $\mathrm{~nm}$ & $\mathrm{~nm}$ & -1.59 & -1.56 \\
\hline Well 1 & 588.98 & 585.32 & 0.11 & $\mathrm{~nm}$ & $\mathrm{~nm}$ & $\mathrm{~nm}$ & $\mathrm{~nm}$ & -0.77 & $\mathrm{~nm}$ & $\mathrm{~nm}$ & -1.46 & -1.57 & -1.61 \\
\hline Well 2 & 591.75 & 588.51 & $\mathrm{~nm}$ & $\mathrm{~nm}$ & 3.09 & 3.11 & 2.77 & 2.46 & 2.47 & $\mathrm{~nm}$ & 1.76 & 1.61 & 1.54 \\
\hline Well 3 & 589.37 & 585.24 & 0.56 & 0.21 & -0.07 & $\mathrm{~nm}$ & $\mathrm{~nm}$ & -0.89 & $\mathrm{~nm}$ & $\mathrm{~nm}$ & -1.49 & -1.63 & -1.65 \\
\hline Well 4 & 591.42 & 588.70 & $\mathrm{~nm}$ & $\mathrm{~nm}$ & $\mathrm{~nm}$ & $\mathrm{~nm}$ & 3.37 & 2.66 & 2.85 & $\mathrm{~nm}$ & 1.97 & 1.78 & 1.72 \\
\hline Well 5 & 588.92 & 584.88 & 1.26 & 0.94 & 0.73 & 0.88 & 0.06 & -1.14 & $\mathrm{~nm}$ & $\mathrm{~nm}$ & -1.82 & -2.03 & -2.03 \\
\hline Gage C & 588.84 & 584.81 & $\mathrm{~nm}$ & $\mathrm{~nm}$ & $\mathrm{~nm}$ & $\mathrm{~nm}$ & $\mathrm{~nm}$ & -1.18 & $\mathrm{~nm}$ & $\mathrm{~nm}$ & $\mathrm{~nm}$ & -2.05 & -2.05 \\
\hline Well 6 & 593.88 & 589.98 & 0.92 & 0.70 & 0.67 & 0.40 & 0.61 & 0.50 & $\mathrm{~nm}$ & 0.47 & 0.68 & 0.73 & 0.53 \\
\hline Gage D & 593.02 & 589.07 & $\mathrm{~nm}$ & -0.20 & $\mathrm{~nm}$ & -0.14 & -0.08 & -0.10 & $\mathrm{~nm}$ & $\mathrm{~nm}$ & $\mathrm{~nm}$ & -0.11 & -0.20 \\
\hline Well 7 & 592.97 & 589.05 & 0.39 & 0.13 & $\mathrm{~nm}$ & 0.05 & -0.06 & -0.11 & $\mathrm{~nm}$ & $\mathrm{~nm}$ & $\mathrm{~nm}$ & $\mathrm{~nm}$ & -0.90 \\
\hline Well 8 & 593.11 & 589.12 & 1.16 & 0.91 & 0.77 & 0.85 & 0.78 & 0.60 & $\mathrm{~nm}$ & 0.28 & $\mathrm{~nm}$ & $\mathrm{~nm}$ & $\mathrm{~nm}$ \\
\hline Well 9 & 591.13 & 587.46 & -0.28 & -0.48 & $\mathrm{~nm}$ & $\mathrm{~nm}$ & -0.56 & -0.66 & $\mathrm{~nm}$ & $\mathrm{~nm}$ & $\mathrm{~nm}$ & -0.66 & -0.72 \\
\hline Gage E & 591.23 & 587.19 & -0.50 & -0.66 & -0.74 & -0.70 & -0.75 & -0.86 & $\mathrm{~nm}$ & $\mathrm{~nm}$ & $\mathrm{~nm}$ & -0.95 & -0.92 \\
\hline Well 10 & 592.20 & 588.30 & 0.65 & 0.39 & 0.32 & 0.38 & 0.34 & 0.18 & 0.43 & $\mathrm{~nm}$ & $\mathrm{~nm}$ & $\mathrm{~nm}$ & 0.08 \\
\hline Well 11 & 592.88 & 588.86 & 1.40 & 0.95 & 0.84 & 0.94 & 0.85 & 0.68 & 1.28 & -0.28 & $\mathrm{~nm}$ & $\mathrm{~nm}$ & -0.66 \\
\hline Gage F & 589.51 & 585.51 & -1.76 & -2.34 & $\mathrm{~nm}$ & $\mathrm{~nm}$ & $\mathrm{~nm}$ & -2.58 & -2.24 & $\mathrm{~nm}$ & $\mathrm{~nm}$ & -2.54 & -2.45 \\
\hline Well 12 & 590.08 & 585.79 & -1.52 & $\mathrm{~nm}$ & $\mathrm{~nm}$ & $\mathrm{~nm}$ & $\mathrm{~nm}$ & -2.33 & $\mathrm{~nm}$ & $\mathrm{~nm}$ & $\mathrm{~nm}$ & -2.21 & -2.15 \\
\hline Well 13 & 592.59 & 588.65 & 1.60 & 1.38 & 1.30 & 1.38 & 1.34 & 1.13 & 1.50 & 1.04 & 0.83 & 1.02 & 0.36 \\
\hline Well 14 & 590.41 & 586.62 & -0.12 & $\mathrm{~nm}$ & $\mathrm{~nm}$ & -0.18 & $\mathrm{~nm}$ & -0.35 & $\mathrm{~nm}$ & $\mathrm{~nm}$ & $\mathrm{~nm}$ & -0.37 & -0.52 \\
\hline Gage G & 590.49 & 586.54 & -0.20 & $\mathrm{~nm}$ & $\mathrm{~nm}$ & -0.38 & $\mathrm{~nm}$ & -0.48 & $\mathrm{~nm}$ & $\mathrm{~nm}$ & $\mathrm{~nm}$ & -0.51 & -0.66 \\
\hline Well 15 & 592.59 & 588.50 & 2.14 & 1.86 & 1.75 & 1.84 & 1.65 & 1.39 & 1.82 & 1.51 & 1.21 & 1.32 & 1.08 \\
\hline Well 16 & 590.84 & 586.91 & 1.00 & 0.47 & 0.28 & 0.42 & $\mathrm{~nm}$ & -0.28 & $\mathrm{~nm}$ & $\mathrm{~nm}$ & -0.61 & -0.56 & -0.65 \\
\hline Well 17 & 591.37 & 588.33 & 3.06 & 2.53 & 2.29 & 2.38 & 1.89 & 1.63 & 2.20 & 1.88 & 1.27 & 1.36 & 0.82 \\
\hline Well 18 & 589.18 & 585.41 & 0.22 & -0.30 & $\mathrm{~nm}$ & $\mathrm{~nm}$ & $\mathrm{~nm}$ & -1.22 & $\mathrm{~nm}$ & $\mathrm{~nm}$ & -1.48 & -1.49 & -1.56 \\
\hline Gage H & 589.46 & 585.47 & $\mathrm{~nm}$ & -0.26 & -0.49 & -0.48 & $\mathrm{~nm}$ & -1.14 & $\mathrm{~nm}$ & $\mathrm{~nm}$ & $\mathrm{~nm}$ & -1.40 & -1.48 \\
\hline Well 19 & 586.98 & 583.10 & 2.30 & 1.95 & 1.89 & 1.90 & 1.41 & 1.26 & 1.52 & $\mathrm{~nm}$ & 0.31 & 0.36 & -0.24 \\
\hline Well 20 & 587.99 & 584.00 & 0.40 & $\mathrm{~nm}$ & 0.32 & $\mathrm{~nm}$ & $\mathrm{~nm}$ & $\mathrm{~nm}$ & $\mathrm{~nm}$ & $\mathrm{~nm}$ & $\mathrm{~nm}$ & 0.04 & 0.01 \\
\hline Well 21 & 587.30 & 583.41 & -0.11 & $\mathrm{~nm}$ & -0.12 & $\mathrm{~nm}$ & $\mathrm{~nm}$ & $\mathrm{~nm}$ & $\mathrm{~nm}$ & $\mathrm{~nm}$ & $\mathrm{~nm}$ & $\mathrm{~nm}$ & -0.48 \\
\hline Gage A & 587.37 & 583.21 & -0.14 & $\mathrm{~nm}$ & $\mathrm{~nm}$ & $\mathrm{~nm}$ & $\mathrm{~nm}$ & $\mathrm{~nm}$ & $\mathrm{~nm}$ & $\mathrm{~nm}$ & $\mathrm{~nm}$ & $\mathrm{~nm}$ & -0.49 \\
\hline Well 22 & 587.55 & 583.61 & 0.10 & $\mathrm{~nm}$ & 0.04 & $\mathrm{~nm}$ & $\mathrm{~nm}$ & $\mathrm{~nm}$ & $\mathrm{~nm}$ & $\mathrm{~nm}$ & -0.48 & -0.28 & -0.34 \\
\hline
\end{tabular}


Table 1-2. Depth to water at gages and in wells in the vicinity of Spring Bluff Nature Preserve, Lake County, Illinois. - Continued

[nm, not measured; bold denotes ice present; underline denotes gage is dry, value is maximum possible water level; *, flow on river at gage DR3; bold and underline denotes gage is submerged, value is minimum possible water level]

\begin{tabular}{|c|c|c|c|c|c|c|c|c|c|c|c|}
\hline \multirow{2}{*}{$\begin{array}{l}\text { Gage } \\
\text { or well }\end{array}$} & \multirow{2}{*}{$\begin{array}{c}\text { Elevation } \\
\text { of top of } \\
\text { casing } \\
\text { (feet) }\end{array}$} & \multirow{2}{*}{$\begin{array}{l}\text { Elevation } \\
\text { of land } \\
\text { surface } \\
\text { (feet) }\end{array}$} & \multicolumn{9}{|c|}{ Depth to water in feet above (negative value) and below (positive value) land surface on given date } \\
\hline & & & 03/27/2008 & 04/10/2008 & 04/30/2008 & 05/06/2008 & $05 / 14 / 2008$ & 06/06/2008 & $06 / 12 / 2008$ & 07/08/2008 & 08/28/2008 \\
\hline Gage B & 589.34 & 585.34 & -1.68 & -1.62 & -2.40 & -1.20 & -1.08 & -1.00 & $\mathrm{~nm}$ & -0.97 & $\mathrm{~nm}$ \\
\hline Well 1 & 588.98 & 585.32 & -1.72 & -1.64 & 0.00 & -1.22 & -1.12 & -1.04 & $\mathrm{~nm}$ & -0.98 & 0.54 \\
\hline Well 2 & 591.75 & 588.51 & 1.49 & 1.56 & 1.96 & 2.00 & 2.13 & 2.20 & $\mathrm{~nm}$ & 2.27 & $\mathrm{~nm}$ \\
\hline Well 3 & 589.37 & 585.24 & -1.75 & -1.68 & -1.31 & -1.26 & -1.15 & -1.08 & $\mathrm{~nm}$ & -1.02 & 0.48 \\
\hline Well 4 & 591.42 & 588.70 & 1.68 & 1.78 & 2.20 & 2.26 & 2.40 & 2.44 & $\mathrm{~nm}$ & 2.55 & $\mathrm{~nm}$ \\
\hline Well 5 & 588.92 & 584.88 & -2.15 & $\mathrm{~nm}$ & -1.60 & -1.49 & -1.33 & -1.26 & $\mathrm{~nm}$ & -1.18 & 0.64 \\
\hline Gage C & 588.84 & 584.81 & -1.96 & -2.01 & -1.61 & -1.52 & -1.35 & -1.28 & $\mathrm{~nm}$ & -1.17 & $\mathrm{~nm}$ \\
\hline Well 6 & 593.88 & 589.98 & 0.68 & 0.63 & 0.76 & 0.79 & 0.48 & 0.31 & $\mathrm{~nm}$ & 0.50 & 2.01 \\
\hline Gage D & 593.02 & 589.07 & -0.18 & -0.17 & -0.08 & -0.07 & $\mathrm{~nm}$ & -0.10 & $\mathrm{~nm}$ & $\mathrm{~nm}$ & $\mathrm{~nm}$ \\
\hline Well 7 & 592.97 & 589.05 & -0.86 & -0.85 & -0.76 & -0.72 & -0.74 & -0.78 & $\mathrm{~nm}$ & -0.61 & 1.32 \\
\hline Well 8 & 593.11 & 589.12 & $\mathrm{~nm}$ & 0.57 & 0.79 & 0.83 & 0.76 & 0.61 & $\mathrm{~nm}$ & 0.90 & $\mathrm{~nm}$ \\
\hline Well 9 & 591.13 & 587.46 & -0.83 & -0.85 & -0.65 & -0.60 & -0.56 & -0.57 & $\mathrm{~nm}$ & -0.45 & 1.54 \\
\hline Gage E & 591.23 & 587.19 & -1.04 & -1.07 & -0.86 & -0.85 & -0.78 & -0.80 & $\mathrm{~nm}$ & -0.65 & $\mathrm{~nm}$ \\
\hline Well 10 & 592.20 & 588.30 & 0.11 & 0.08 & 0.29 & 0.31 & 0.38 & 0.33 & $\mathrm{~nm}$ & 0.49 & $\mathrm{~nm}$ \\
\hline Well 11 & 592.88 & 588.86 & $\mathrm{~nm}$ & -0.47 & -0.18 & -0.17 & -0.16 & 1.78 & $\mathrm{~nm}$ & -0.01 & $\mathrm{~nm}$ \\
\hline Gage F & 589.51 & 585.51 & -2.76 & -2.75 & -2.34 & -2.34 & -2.25 & -2.26 & $\mathrm{~nm}$ & -2.00 & $\mathrm{~nm}$ \\
\hline Well 12 & 590.08 & 585.79 & -2.42 & $\mathrm{~nm}$ & -2.01 & -1.99 & -1.92 & -1.92 & $\mathrm{~nm}$ & -1.79 & 0.34 \\
\hline Well 13 & 592.59 & 588.65 & 1.89 & 0.91 & 1.37 & 1.38 & 1.43 & 0.96 & $\mathrm{~nm}$ & 1.32 & 0.00 \\
\hline Well 14 & 590.41 & 586.62 & $\mathrm{~nm}$ & $\mathrm{~nm}$ & -0.29 & -0.27 & -0.28 & -0.36 & $\mathrm{~nm}$ & -0.17 & 1.62 \\
\hline Gage G & 590.49 & 586.54 & -0.65 & -0.07 & -0.42 & -0.43 & -0.40 & -0.50 & $\mathrm{~nm}$ & -0.27 & $\mathrm{~nm}$ \\
\hline Well 15 & 592.59 & 588.50 & 1.27 & 1.26 & 1.69 & 1.72 & 1.78 & 1.52 & $\mathrm{~nm}$ & 1.81 & $\mathrm{~nm}$ \\
\hline Well 16 & 590.84 & 586.91 & -0.60 & -0.59 & -0.02 & 0.02 & 0.21 & 0.04 & $\mathrm{~nm}$ & 0.38 & $\mathrm{~nm}$ \\
\hline Well 17 & 591.37 & 588.33 & 1.28 & 1.33 & 1.73 & 1.72 & 1.84 & 1.77 & $\mathrm{~nm}$ & 2.07 & $\mathrm{~nm}$ \\
\hline Well 18 & 589.18 & 585.41 & -1.53 & -1.48 & -1.24 & -1.21 & -1.10 & -0.83 & $\mathrm{~nm}$ & -0.76 & 1.01 \\
\hline Gage H & 589.46 & 585.47 & -1.46 & -1.40 & -1.16 & -1.14 & -1.02 & -0.76 & $\mathrm{~nm}$ & -0.63 & $\mathrm{~nm}$ \\
\hline Well 19 & 586.98 & 583.10 & -0.20 & -0.27 & -0.19 & -0.17 & $\mathrm{~nm}$ & $\mathrm{~nm}$ & -0.23 & 0.22 & 1.85 \\
\hline Well 20 & 587.99 & 584.00 & $\mathrm{~nm}$ & 0.16 & 0.23 & 0.25 & 0.26 & $\mathrm{~nm}$ & 0.21 & 0.15 & 0.77 \\
\hline Well 21 & 587.30 & 583.41 & -0.33 & -0.18 & -0.16 & -0.14 & -0.16 & $\mathrm{~nm}$ & -0.18 & -0.24 & 0.10 \\
\hline Gage A & 587.37 & 583.21 & -0.37 & -0.18 & -0.17 & -0.16 & -0.16 & $\mathrm{~nm}$ & -0.17 & -0.22 & $\mathrm{~nm}$ \\
\hline Well 22 & 587.55 & 583.61 & -0.21 & -0.14 & -0.08 & -0.07 & -0.07 & $\mathrm{~nm}$ & -0.13 & -0.13 & 0.27 \\
\hline
\end{tabular}


Table 1-3. Water-level elevation at gages and in wells in the vicinity of Spring Bluff Nature Preserve, Lake County, Illinois.

[nm, not measured; bold denotes ice present; underline denotes gage is dry, value is maximum possible water level; *, flow on river at gage DR3; bold and underline denotes gage is submerged, value is minimum possible water level]

\begin{tabular}{|c|c|c|c|c|c|c|c|c|c|c|}
\hline Gage & \multicolumn{10}{|c|}{ Water-level elevation, in feet above North American Vertical Datum of 1988, on given date } \\
\hline W1 & 584.67 & $\mathrm{~nm}$ & 584.60 & 585.23 & 586.72 & 585.28 & 584.87 & 584.60 & 584.73 & 584.41 \\
\hline DD1 & $\mathrm{nm}$ & 596.36 & 596.31 & 596.50 & 598.29 & 596.37 & 596.22 & 596.13 & 596.22 & 596.10 \\
\hline W3 & 588.41 & $\mathrm{~nm}$ & 588.42 & 588.53 & 589.21 & 588.51 & 588.44 & 588.44 & 588.45 & 588.28 \\
\hline DD2 & 588.46 & $\mathrm{~nm}$ & 588.46 & 588.57 & 589.13 & 588.55 & 588.47 & 588.37 & $\mathrm{~nm}$ & 588.32 \\
\hline DD4 & 593.10 & $\mathrm{~nm}$ & 593.10 & $\mathrm{~nm}$ & 593.35 & 593.07 & 593.04 & 593.04 & 593.03 & 593.09 \\
\hline SG1 & 587.48 & $\mathrm{~nm}$ & 587.48 & 588.09 & 588.52 & 588.22 & 588.09 & 587.78 & 588.09 & 587.48 \\
\hline W4 & $\mathrm{nm}$ & 585.67 & 585.68 & 585.76 & 586.29 & 585.98 & 585.86 & 585.74 & 585.77 & 585.67 \\
\hline DD3 & 582.00 & $\mathrm{~nm}$ & 581.79 & 582.15 & 582.88 & 582.25 & 582.15 & 581.97 & 582.07 & 581.45 \\
\hline DR1 & $\mathrm{nm}$ & 592.27 & 592.28 & 592.50 & 594.49 & 592.53 & 592.42 & 592.38 & 592.42 & 592.37 \\
\hline
\end{tabular}

\begin{tabular}{|c|c|c|c|c|c|c|c|c|c|c|}
\hline Gage & \multicolumn{10}{|c|}{ Water-level elevation, in feet above North American Vertical Datum of 1988 , on given date } \\
\hline W1 & 584.39 & 584.37 & 584.39 & 584.34 & 584.26 & 584.21 & 584.22 & 583.96 & 583.88 & 583.84 \\
\hline DD1 & 596.10 & 596.09 & 596.11 & 596.11 & 596.10 & 596.09 & 596.10 & 596.08 & 596.10 & 596.08 \\
\hline W3 & 588.28 & 588.22 & 588.23 & 588.19 & 587.93 & 587.78 & 587.76 & 587.47 & 587.35 & 587.27 \\
\hline DD2 & 588.27 & 588.15 & 588.26 & 588.07 & 587.98 & 587.82 & 587.80 & 587.50 & 587.43 & 587.35 \\
\hline DD4 & 593.08 & 593.06 & 593.04 & 593.04 & 592.94 & $\underline{592.94}$ & $\underline{592.94}$ & $\underline{592.94}$ & $\underline{592.94}$ & $\underline{592.94}$ \\
\hline SG1 & 587.35 & 587.12 & 587.45 & 587.01 & 586.84 & 586.65 & 586.7 & 586.41 & 586.32 & 586.29 \\
\hline W4 & 585.63 & 585.53 & 585.58 & 585.39 & 585.24 & 585.07 & 585.07 & 584.79 & 584.71 & 584.73 \\
\hline DD3 & $\underline{581.40}$ & $\underline{581.40}$ & $\underline{581.40}$ & $\underline{581.40}$ & $\underline{581.40}$ & $\underline{581.40}$ & $\underline{581.40}$ & $\underline{581.40}$ & $\underline{581.40}$ & $\underline{581.40}$ \\
\hline DR1 & 592.36 & 592.33 & 592.36 & 592.36 & 592.32 & 592.32 & 592.33 & 592.3 & 592.31 & 592.13 \\
\hline \multirow{2}{*}{ Gage } & \multicolumn{10}{|c|}{ Water-level elevation, in feet above North American Vertical Datum of 1988 , on given date } \\
\hline & 08/21/2007 & 08/24/2007 & 08/30/2007 & 09/12/2007 & 09/19/2007 & $10 / 06 / 2007$ & $10 / 19 / 2007$ & $10 / 30 / 2007$ & $11 / 09 / 2007$ & $11 / 17 / 2007$ \\
\hline W1 & 587.32 & 586.29 & 585.26 & 584.63 & 584.37 & 584.46 & 585.22 & 584.58 & 584.51 & 584.49 \\
\hline DD1 & 597.98 & 597.82 & 596.37 & 596.32 & 596.22 & 596.22 & 596.48 & 596.32 & 596.32 & 596.28 \\
\hline W3 & 589.08 & 588.88 & 588.45 & 588.20 & 588.02 & 588.36 & 588.48 & 588.35 & 589.17 & 588.20 \\
\hline DD2 & 589.12 & 588.9 & 588.49 & 588.22 & 588.06 & 588.39 & 588.52 & 588.39 & 588.27 & 588.24 \\
\hline W2 & 586.44 & 586.90 & 586.32 & 585.75 & 585.44 & 585.20 & 584.96 & 584.66 & 583.97 & $\underline{583.52}$ \\
\hline DD4 & 593.25 & 593.16 & 593.11 & 593.09 & 593.04 & 593.03 & 593.07 & 593.05 & 593.01 & 593.01 \\
\hline
\end{tabular}


Table 1-3. Water-level elevation at gages and in wells in the vicinity of Spring Bluff Nature Preserve, Lake County, Illinois. -Continued

[nm, not measured; bold denotes ice present; underline denotes gage is dry, value is maximum possible water level; *, flow on river at gage DR3; bold and underline denotes gage is submerged, value is minimum possible water level]

\begin{tabular}{|c|c|c|c|c|c|c|c|c|c|}
\hline \multirow{2}{*}{ Gage } & \multicolumn{9}{|c|}{ Water-level elevation, in feet above North American Vertical Datum of 1988, on given date } \\
\hline & $11 / 23 / 2007$ & $11 / 28 / 2007$ & $12 / 07 / 2007$ & $12 / 15 / 2007$ & $12 / 20 / 2007$ & $01 / 01 / 2008$ & 01/10/2008 & $01 / 23 / 2008$ & $02 / 14 / 2008$ \\
\hline W1 & 584.52 & 584.52 & 585.16 & 585.36 & 585.00 & 585.23 & 585.80 & 586.31 & 585.00 \\
\hline DD1 & 596.29 & 596.26 & 596.42 & 596.76 & 596.60 & 596.62 & 597.40 & 596.70 & 597.58 \\
\hline W3 & 588.22 & 589.10 & 588.94 & 588.68 & 588.66 & 588.99 & 588.46 & 588.26 & 588.60 \\
\hline DD2 & 588.26 & 588.34 & 588.58 & 588.64 & 588.62 & 588.68 & 588.66 & 588.5 & 588.74 \\
\hline W2 & $\underline{583.52}$ & $\underline{583.52}$ & $\underline{583.52}$ & 584.76 & 585.06 & 585.92 & 586.26 & 585.95 & 586.37 \\
\hline DD4 & 593.02 & 593.00 & 593.05 & 593.07 & 593.05 & 593.04 & 593.06 & 593.09 & 593.37 \\
\hline SG1 & 587.21 & 587.29 & 587.8 & 587.88 & 587.8 & 587.92 & 588.06 & 587.73 & 588.26 \\
\hline W4 & 585.73 & 586.62 & 586.57 & 585.97 & 585.97 & 586.04 & 586.21 & $\mathbf{5 8 6 . 0 7}$ & 586.53 \\
\hline DD3 & $\underline{581.40}$ & $\underline{581.40}$ & $\underline{581.40}$ & $\underline{581.40}$ & $\underline{581.40}$ & 582.10 & 582.53 & 582.30 & $\underline{581.40}$ \\
\hline DR1 & 592.32 & 592.32 & 592.29 & 592.51 & 592.31 & 592.45 & 592.99 & 592.51 & 592.71 \\
\hline DR2 & 584.37 & 584.39 & 584.71 & 584.68 & 584.52 & 584.64 & 584.84 & 584.64 & 584.82 \\
\hline DR3 & 580.25 & 580.02 & 581.00 & 578.00 & 577.84 & 577.97 & 578.26 & 578.04 & 578.72 \\
\hline \multirow{2}{*}{ Gage } & \multicolumn{9}{|c|}{ Water-level elevation, in feet above North American Vertical Datum of 1988, on given date } \\
\hline & 02/29/2008 & 03/14/2008 & 03/19/2008 & 03/27/2008 & 04/03/2008 & 04/10/2008 & 04/30/2008 & 05/14/2008 & $06 / 12 / 2008$ \\
\hline W1 & 585.82 & 585.66 & 586.56 & 586.12 & 585.86 & 586.16 & 584.72 & 584.56 & 585.62 \\
\hline DD1 & 596.56 & 597.38 & 597.50 & 597.77 & 597.27 & 597.99 & 597.58 & 596.60 & 597.19 \\
\hline W3 & 588.64 & 588.58 & $\underline{591.66}$ & 588.67 & 588.50 & 588.62 & 588.16 & 588.12 & 588.37 \\
\hline DD2 & 589.06 & 588.78 & 588.6 & 588.71 & 588.54 & 588.65 & 588.22 & 588.19 & 588.41 \\
\hline W2 & 586.85 & 586.58 & $\underline{587.05}$ & 586.85 & $\underline{587.05}$ & 586.45 & 586.45 & 586.30 & $\underline{587.05}$ \\
\hline DD4 & 593.32 & 593.02 & $\mathrm{~nm}$ & 593.06 & 593.04 & 592.87 & 592.92 & 593.03 & 593.02 \\
\hline SG1 & 588.2 & 588.14 & $\mathrm{~nm}$ & 588.09 & 588.18 & 588.38 & 588.26 & 588.22 & 588.33 \\
\hline W4 & 586.77 & 586.87 & 586.80 & 586.79 & 586.58 & 586.39 & 586.12 & 586.06 & 586.26 \\
\hline DD3 & $\underline{581.40}$ & 582.37 & $\mathrm{~nm}$ & 582.90 & 582.94 & 582.82 & 582.35 & 582.24 & 582.80 \\
\hline DR1 & 592.39 & 592.51 & 593.00 & 593.41 & 592.98 & 592.98 & 592.98 & $\mathrm{~nm}$ & $\mathrm{~nm}$ \\
\hline DR2 & 584.90 & 585.14 & 585.00 & 585.27 & 584.92 & 585.15 & 584.75 & 584.82 & 584.87 \\
\hline DR3 & 578.88 & 577.82 & $\mathrm{~nm}$ & 578.34 & 578.67 & 578.28 & 578.60 & 579.14 & 578.42 \\
\hline
\end{tabular}


This page is intentionally blank. 

